Portland State University

PDXScholar

Spring 6-3-2014

\title{
Exploring Colonization and Ethnogenesis through an Analysis of the Flaked Glass Tools of the Lower Columbia Chinookans and Fur Traders
}

Stephanie Catherine Simmons

Portland State University

Follow this and additional works at: https://pdxscholar.library.pdx.edu/open_access_etds

Part of the Indigenous Studies Commons, and the Social and Cultural Anthropology Commons Let us know how access to this document benefits you.

\section{Recommended Citation}

Simmons, Stephanie Catherine, "Exploring Colonization and Ethnogenesis through an Analysis of the Flaked Glass Tools of the Lower Columbia Chinookans and Fur Traders" (2014). Dissertations and Theses. Paper 1804.

https://doi.org/10.15760/etd.1804

This Thesis is brought to you for free and open access. It has been accepted for inclusion in Dissertations and Theses by an authorized administrator of PDXScholar. Please contact us if we can make this document more accessible: pdxscholar@pdx.edu. 
Exploring Colonization and Ethnogenesis through an Analysis of the Flaked Glass Tools of the Lower Columbia Chinookans and Fur Traders

by

Stephanie Catherine Simmons

A thesis submitted in partial fulfillment of the requirements for the degree of

\author{
Master of Science \\ in \\ Anthropology
}

Thesis Committee:

Kenneth M. Ames, Chair

Douglas C. Wilson

Shelby Anderson

Portland State University

2014 


\begin{abstract}
At the end of the $18^{\text {th }}$ century, Anglo Americans and Europeans entered the mouth of the Columbia River for the first time. There they encountered large villages of Chinookan and other Native Americans. Soon afterwards, the Chinookan People became involved in the global fur trade. Pelts, supplies, and native made goods were exchanged with fur traders, who in return provided Chinookans with a number of trade goods. Over the next 40 years, life changed greatly for the Chinookans; new trade and political alliances were created, foreign goods were introduced, and diseases killed large portions of the population (Hajda 1984; Gibson 1992; Schwantes 1996; Boyd 2011; Boyd et al. 2013). Additionally, fur trade forts, like the Hudson's Bay Company's (HBC) Fort Vancouver, were established. At these forts, new multiethnic communities were created to support the fur trade economy (Hussey 1957; Kardas 1971; Warner and Munnik 1972; Erigero 1992; Burley 1997; Mackie 1997; Wilson 2010).
\end{abstract}

This thesis is an historical archaeological study of how Chinookan peoples at three villages and employees of the later multicultural Village at Fort Vancouver negotiated the processes of contact and colonization. Placed in the theoretical framework of practice theory, everyday ordinary activities are studied to understand how cultural identities are created, reinforced, and changed (Lightfoot et al. 1998; Martindale 2009; Voss 2008). Additionally uneven power relationships are examined, in this case between the colonizer and the colonized, which could lead to subjugation but also resistance (Silliman 2001). In order to investigate these issues, this thesis studies how the new 
foreign material of vessel glass was and was not used during the everyday practice of tool production.

Archaeological studies have found that vessel glass, which has physical properties similar to obsidian, was used to create a variety of tool forms by cultures worldwide (Conte and Romero 2008). Modified glass studies (Harrison 2003; Martindale and Jurakic 2006) have demonstrated that they can contribute important new insights into how cultures negotiated colonization. In this study, modified glass tools from three contact period Chinookan sites: Cathlapotle, Meier, and Middle Village, and the later multiethnic Employee Village of Fort Vancouver were examined. Glass tool and debitage analysis based on lithic macroscopic analytical techniques was used to determine manufacturing techniques, tool types, and functions. Additionally, these data were compared to previous analyses of lithics and trade goods at the study sites.

This thesis demonstrates that Chinookans modified glass into tools, though there was variation in the degree to which glass was modified and the types of tools that were produced between sites. Some of these differences are probably related to availability, how glass was conceptualized by Native Peoples, or other unidentified causes. This study suggests that in some ways glass was just another raw material, similar to stone, that was used to create tools that mirrored the existing lithic technology. However at Cathlapotle at least, glass appears to have been relatively scarce and perhaps valued even as a status item. While at Middle Village, glass (as opposed to stone) was being used about a third of the time to produce tools. 
Glass tool technology at Cathlapotle, Meier, and Middle Village was very similar to the existing stone tool technology dominated by expedient/low energy tools; however, novel new bottle abraders do appear at Middle Village. This multifaceted response reflects how some traditional lifeways continued, while at the same time new materials and technology was recontextualized in ways that made sense to Chinookan peoples.

Glass tools increase at the Fort Vancouver Employee Village rather than decrease through time. This response appears to be a type of resistance to the HBC's economic hegemony and rigid social structure. Though it is impossible to know if such resistance was consciously acted on or was just part of everyday activities that made sense in the economic climate of the time.

Overall, this thesis demonstrates how a mundane object such as vessel glass, can provide a wealth of information about how groups like the Chinookans dealt with a changing world, and how the multiethnic community at Fort Vancouver dealt with the hegemony of the HBC. Chinookan peoples and the later inhabitants of the Fort Vancouver Employee Village responded to colonization in ways that made sense to their larger cultural system. These responses led to both continuity and change across time. 


\section{Acknowledgements}

This thesis would never have been completed without the expertise, suggestions, and support provided by numerous people during what often felt like an impossible task. I owe a great debt of gratitude to my thesis committee, Dr. Kenneth Ames, Dr. Shelby Anderson, and especially my graduate advisor Dr. Douglas Wilson. Their knowledge, advice, feedback, and patience were invaluable. At Portland State University, Connie Cash was always willing to provide help with school paperwork and lend a kind ear to talk to. I am especially thankful for the opportunity to work at the Fort Vancouver National Historic Site at various times during my graduate study. The Cultural Resource Division there, especially Dr. Robert Cromwell, Beth Horton, Elaine Dorset, Heidi Pierson, and Martin Adams provided knowledge and inspiration, and made it a joyful place to be. My fellow graduate school cohorts and friends, particularly Meris Mullaley, Katie Wynia, Cassie Manetas, and Dana Holschuh offered their help and support, which kept me going. Finally, I cannot express enough the amount of gratitude I owe my parents, brother, Peter, and sister-in-law, Alana. Their love and support saved me countless times. 


\section{Table of Contents}

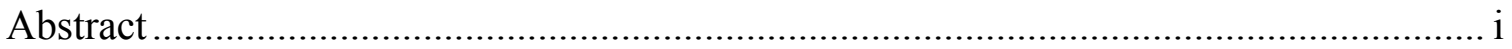

Acknowledgements .............................................................................................. iv

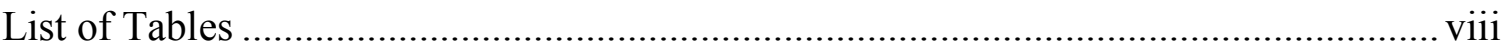

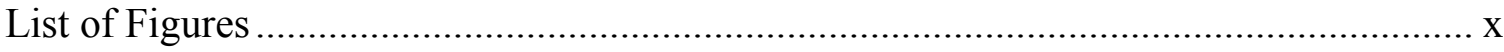

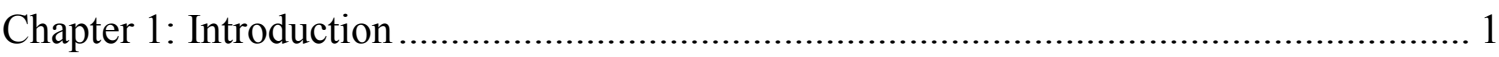

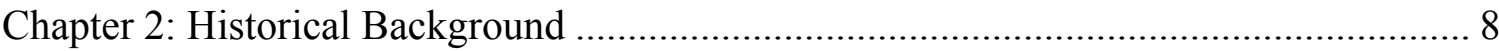

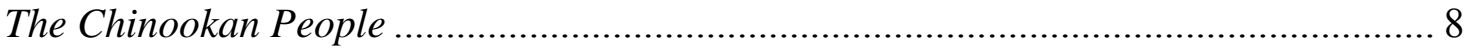

Chinookan Tool Technology ................................................................................. 10

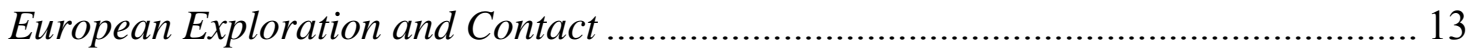

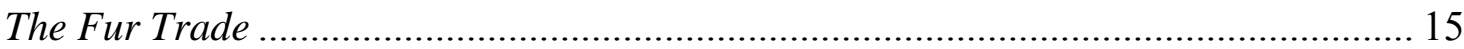

Chinookan People and Fur Trader Relationships ..................................................... 19

Creation of New Multicultural Communities .............................................................. 20

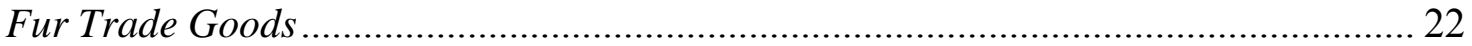

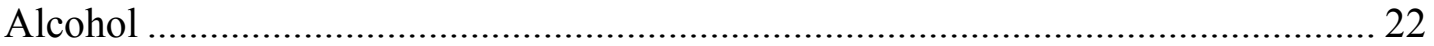

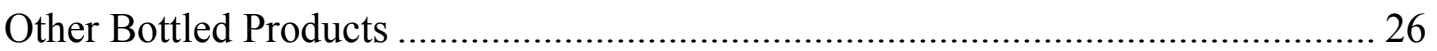

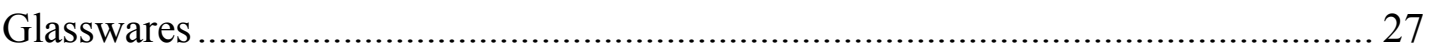

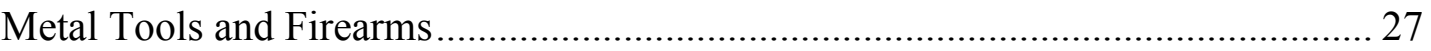

The Impact of Contact and Colonization …………................................................. 30

Chapter 3: History and Archaeology of the Study Sites .................................................. 32

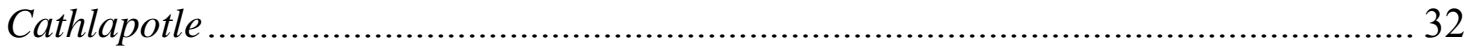

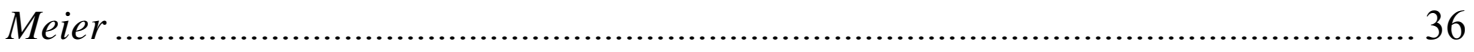

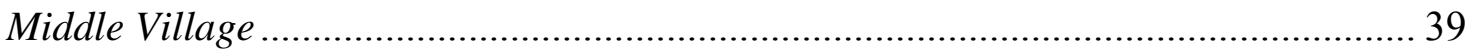

HBC Employee Village ...................................................................................... 43

Chapter 4: Theoretical Background .......................................................................... 48

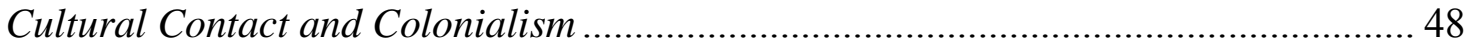

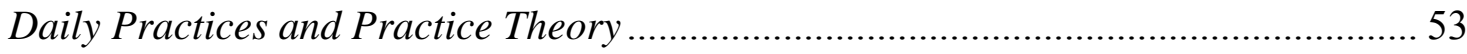

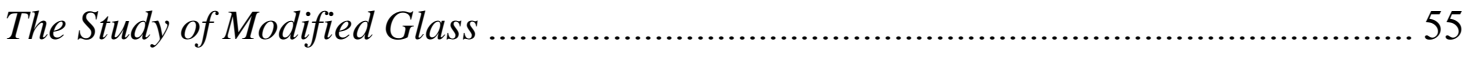

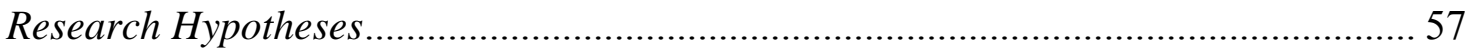

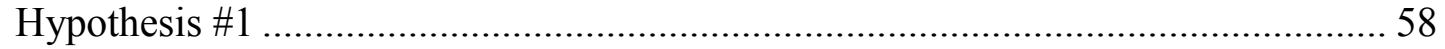




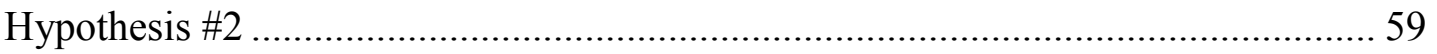

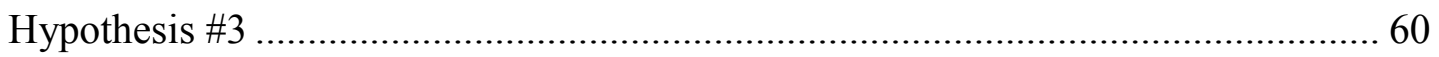

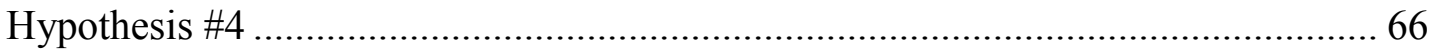

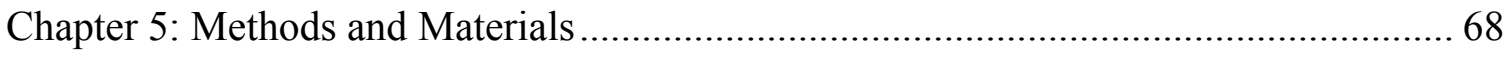

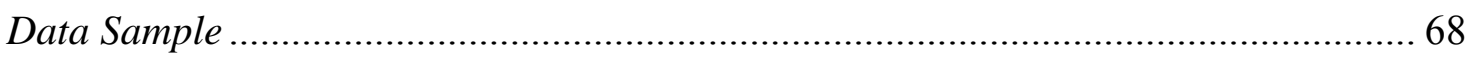

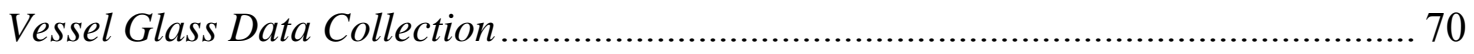

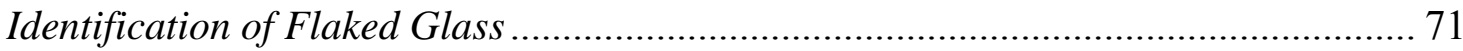

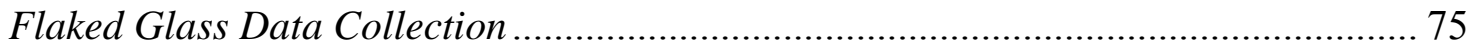

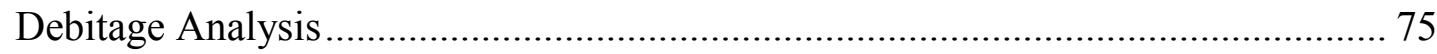

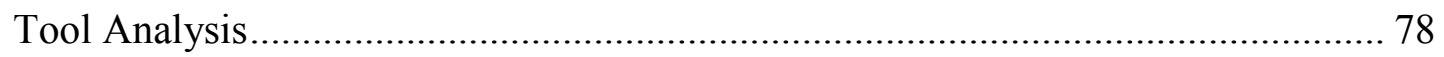

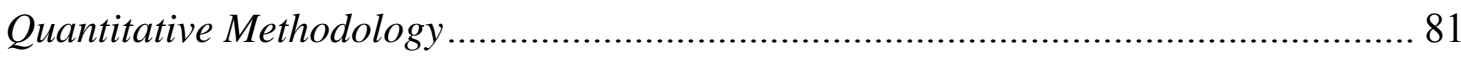

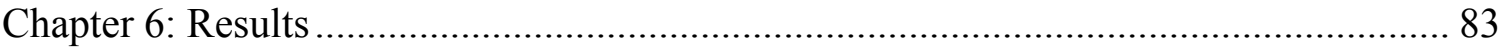

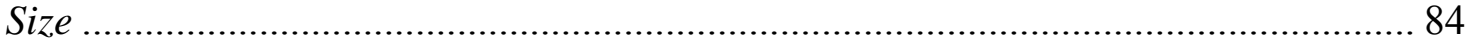

Color

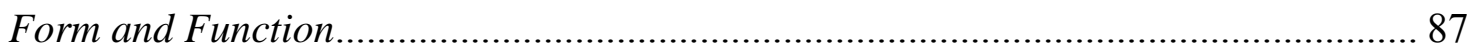

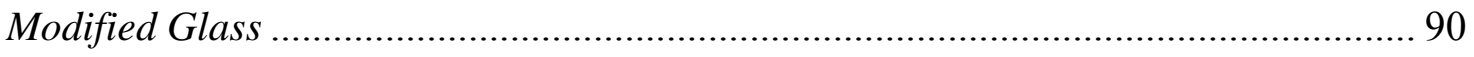

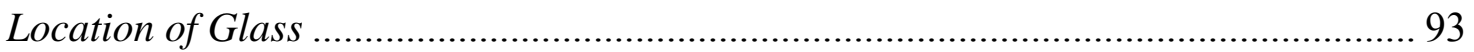

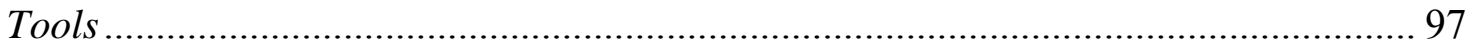

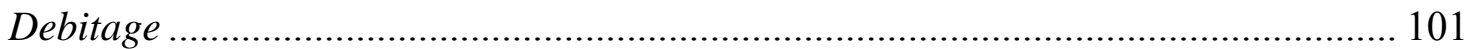

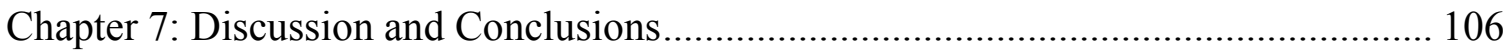

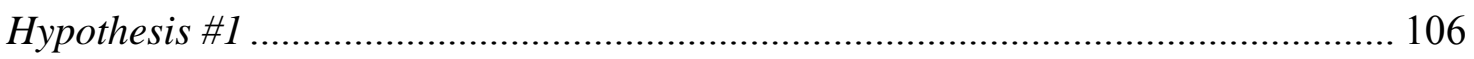

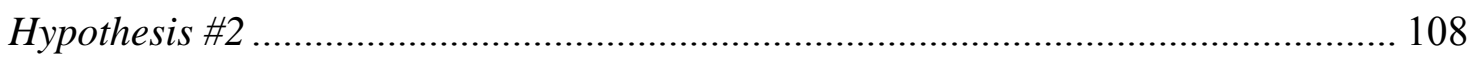

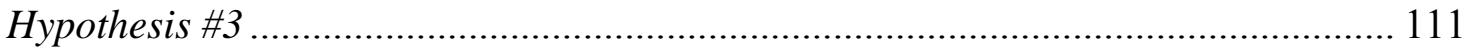

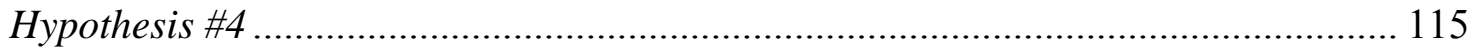

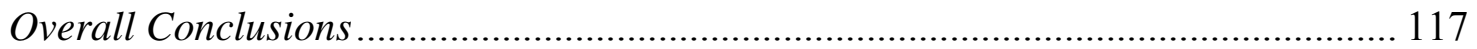

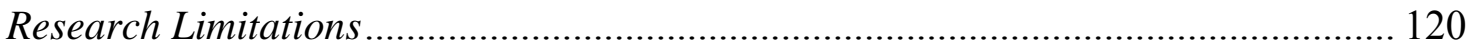

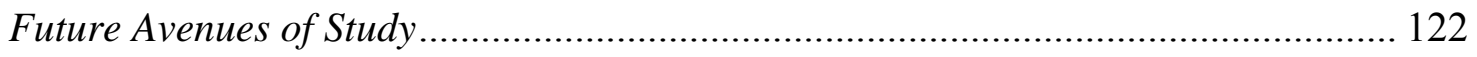

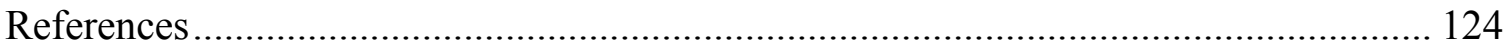

Appendix A: Examples of Modified Glass Tools........................................................ 142

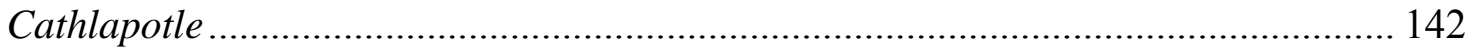

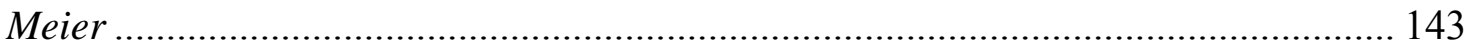


Fort Vancouver Employee Village.

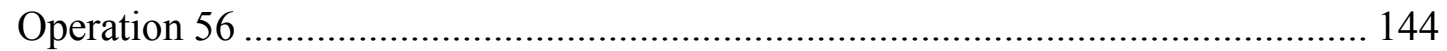

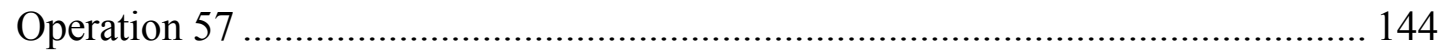




\section{List of Tables}

TABLE 1. Lower Columbia Tool Types (Based On Hamilton 1994).............................. 11

TABLE 2. Comparison of Four Sites .......................................................................... 47

TABLE 3. Variables Recorded For Vessel Glass ............................................................ 70

TABLE 4. Debitage Categories and Definitions ............................................................ 75

TABLE 5. Variables Recorded for Debitage Size 1 ..................................................... 77

TABLE 6. Variables Recorded for Debitage Size 2+................................................... 78

TABLE 7. Glass Tool Classification ............................................................................... 79

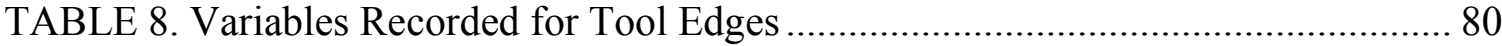

TABLE 9. Inferred Tool Functions based on Hamilton (1994).......................................... 81

TABLE 10. Total Vessel Glass Recovered and Mean Size............................................... 84

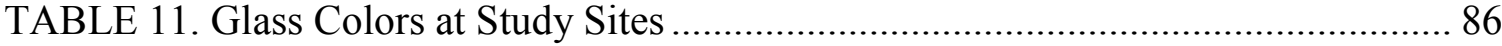

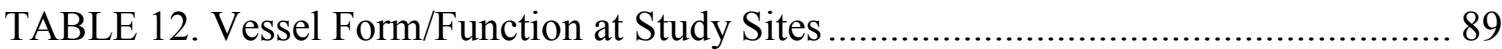

TABLE 13. Modified Glass, Unmodified Glass, Tools, and Debitage at Sites................. 91

TABLE 14. Chi-Square Observed and Expected Values, and Adjusted Residuals.......... 93

TABLE 15. Distribution of Glass at Cathlapotle by Area ............................................... 95

TABLE 16. Distribution of Glass at Meier by Area ………………………………..... 96

TABLE 17. Distribution of Glass at Middle Village by House......................................... 97

TABLE 18. Distribution of Tools and Debitage at Middle Village by House .................. 97

TABLE 19. Inferred Tool Function by Count and Percent at Study Sites ........................ 98

TABLE 20. Expedient versus Formal Tools at Study Sites............................................. 100

TABLE 21. Ratio of Debitage to Tools at Study Sites .................................................... 101

TABLE 22. Debitage Types at Study Sites ............................................................. 102

TABLE 23. Debitage Size Classes at Study Sites ........................................................... 103

TABLE 24. Mean Debitage Platform Thickness for Size 1 and 2+ .............................. 103

TABLE 25. Platform Contour of Size 1 Debitage ........................................................... 103

TABLE 26. Platform Facets and Cortex of Size 2+ Debitage .......................................... 104

TABLE 27. Presence or Absence of Opposing Scars on Size 2+ Debitage ................... 104

TABLE 28. Presence or Absence of Undulations and/or Fissures on Size 2+ Debitage 105 
TABLE 29. Lithic Tools by Function at Three Chinookan Sites ................................ 109

TABLE 30. Trade Goods at Three Chinookan Sites .................................................... 112 


\section{List of Figures}

FIGURE 1. Location of Sites and Major Cities ............................................................ 4

FIGURE 2. Etching by James Swan, ca. 1850s, of a Chinookan Plankhouse................... 9

FIGURE 3. Clamon, Elk Hide Armor with Chinookan Style Figures............................ 16

FIGURE 4. George Gibb's 1851 Sketch of the Fort Vancouver Employee Village ........ 22

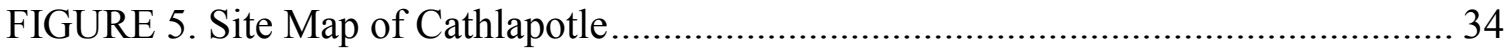

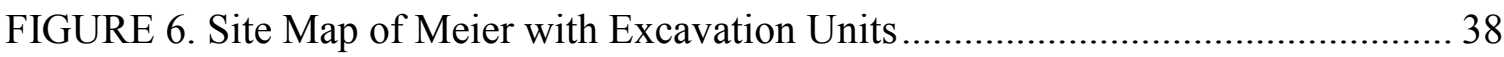

FIGURE 7. Site Map of Middle Village at Station Camp ........................................... 41

FIGURE 8. 1846 Covington Map of Fort Vancouver .............................................. 45

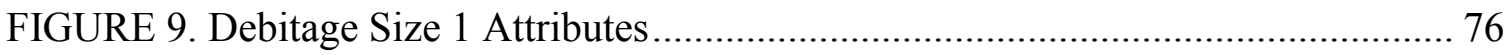

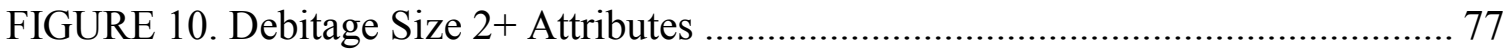

FIGURE 11. Areal Density of Vessel Glass at Four Sites Subdivided by Modification.. 84

FIGURE 12. Distribution of Vessel Glass Size Classes at Four Sites............................. 85

FIGURE 13. Number of Tools Types by Area Excavated ........................................ 100 


\section{Chapter 1: Introduction}

At the end of the $18^{\text {th }}$ century, Europeans and Anglo Americans made their first recorded venture past the mouth of the Columbia River and continued upriver. While these explorers and merchants searched for the elusive Northwest Passage, for land to claim for their respective nations, and for furs to trade in China and Europe, they encountered large villages of Native Peoples along the Columbia (Hajda 1984; Gibson 1992; Schwantes 1996; Boyd 2011; Boyd et al. 2013). After this initial period of "contact," other explorers, fur traders, missionaries, and settlers entered the Lower Columbia region, all the while creating new complex relationships with indigenous populations, including Chinookan peoples (Hajda 1984; Gibson 1992; Boyd 2011). During perhaps as little as 40 years, life changed greatly for Chinookans and other peoples of the Lower Columbia. New trade and political alliances were created, foreign goods were introduced, and diseases killed large portions of the population (Hajda 1984; Boyd 1999, 2011). Toward the end of this period, fur trade forts, like the Hudson's Bay Company’s (HBC) Fort Vancouver, were established. At these forts, new multiethnic communities were created to support the fur trade economy (Hussey 1957; Kardas 1971; Warner and Munnik 1972; Erigero 1992; Burley 1997; Mackie 1997; Wilson 2010).

Unfortunately much of what we know about this early period of contact and later colonization comes from ethnographic and historical sources, which are the products of their author's biases and worldview. At best these sources are one-sided accounts of these cultural interactions (Vibert 1997: xi-xii, 4-5; Rubertone 2000). Archaeology, 
which has already provided a wealth of information on Native lifeways before contact, is increasingly being used to bring about a more complete picture of this post contact period (Smith 2004; Sobel 2004; Minor and Burgess 2009; Wilson et al. 2009; Ames et al. 2011; Sobel 2011; Fuld 2012). The subdiscipline of historical archaeology is especially well suited for the study of this period (Lightfoot 1995). Historical archaeology combines the careful use of documentary sources and the study of the archaeological record to infer past human behaviors (Orser 2004:5; Little 2007:14). Archaeological data can be used to test whether our document based historical knowledge of the past is correct (Little 2007:9, 22-23, 29). Consequently, historical archaeology is able to present a more nuanced window into the past than historical sources could alone (Little 2007:29).

This thesis is an historical archaeological study of how Chinookan peoples at three villages and employees of the later multicultural Employee Village at Fort Vancouver negotiated the processes of contact and colonization. Placed in the theoretical framework of practice theory, everyday ordinary activities are studied to understand how cultural identities are created, reinforced, and changed (Lightfoot et al. 1998; Martindale 2009; Voss 2008). Additionally practice theory is used to examine how uneven power relationships, in this case between the colonizer and the colonized, could lead to subjugation but also resistance (Silliman 2001). In order to investigate these issues, this thesis studies how the new foreign material of vessel glass was and was not used during the everyday practice of tool production.

Previous archaeological research has found that vessel glass, which has physical properties similar to obsidian, was used to create a variety of tool forms by cultures 
worldwide (Conte and Romero 2008). For example, glass has been used to make razors by African Americans on a Louisiana plantation (Wilkie 1996), hide scrapers by the Konso of Southern Ethiopia (Kimura 2006), expedient and formal tools by Australian Aborigines (Cooper and Bowdler 1998; Harrison 2003; Veth and O'Conner 2005), and a variety of tool types by Native Americans in North America (Martindale and Jurakic 2006). One historical account from 1817 even records the use of glass projectile points by Chinook near mouth of the Columbia River (Corney1896:62). Vessel glass as a single aspect of material culture cannot provide a complete picture of the complexity and multifaceted dimensions of change and continuity that took place within these communities. However modified glass studies (Harrison 2003; Martindale and Jurakic 2006) have demonstrated that they can contribute important new insights into how cultures negotiated colonization.

In this study, vessel glass from two contact period Chinookan sites: Cathlapotle (45CL01) and Meier (35CO05) was compared with the glass from the contemporaneous Chinook site of Middle Village (45PC106), and the later multiethnic Employee Village (45CL300) of Fort Vancouver (Figure 1).

The Chinookan villages of Cathlapotle and Meier are on opposite sides of the Columbia River floodplain near present day Portland, Oregon. Both were permanent villages, with occupations beginning in the $15^{\text {th }}$ century. The village of Cathlapotle was composed of six plankhouses, while Meier had one large plankhouse. Cathlapotle is mentioned in a number of historical accounts, and is recorded as interacting directly with fur traders and explorers traveling up and down the Columbia. However, no historical 
accounts exist for Meier. Both sites were abandoned during the beginning of the $19^{\text {th }}$ century, likely as the result of malaria epidemics (Ames et al. 1992, 1999, 2008; Boyd 2011).

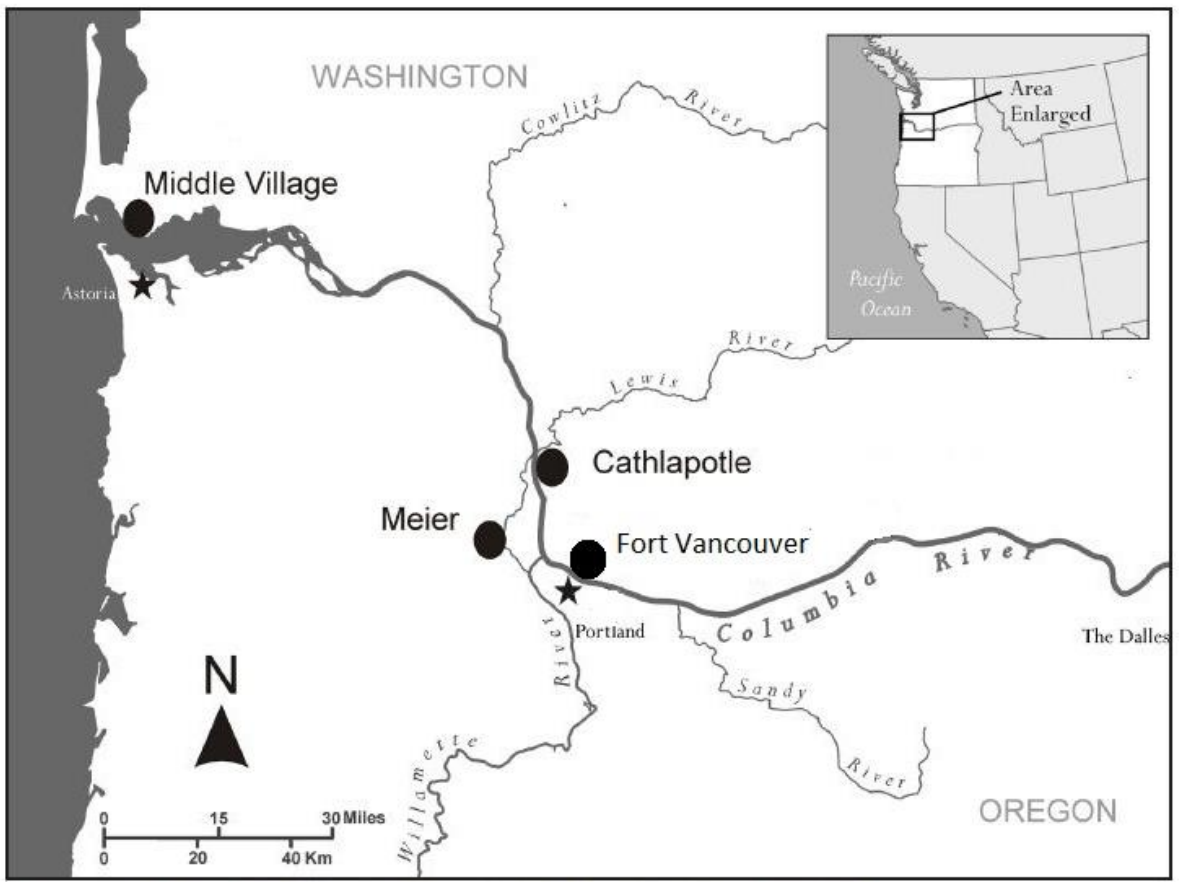

FIGURE 1. Location of Sites and Major Cities (Courtesy of Fort Vancouver National Historic Site)

Middle Village is located near the mouth of the Columbia River, on the north side of the river between Point Ellice and Chinook Point. Archaeological work dates the site to A.D. 1788-1830. However, Chinookan oral traditions say that Middle Village is older, and it is possible that excavations did not discover an older component of the village. Archaeological excavations found that Middle Village was a seasonal summer village with at least five plankhouses present. It was probably established or perhaps enlarged to 
trade with fur traders at the mouth of the Columbia River and nearby Fort Astoria (Wilson et al. 2009).

Fort Vancouver, located in present day Vancouver, Washington, was established in 1824, and, by 1828, had become the HBC's Columbia Department headquarters. The Fort was involved in the fur trade and increasingly in agricultural and industrial projects during its operation. Located to the west of the fort's stockade, the Fort Vancouver Employee Village was a multiethnic community where the majority of the fort's workers lived (Hussey 1957; Erigero 1992). Between ca. 1827 and 1860 an estimated 300 to 1000 people (Mullaley 2011:20) lived in 30 to 50 structures (Hussey 1957:217-218; Thomas and Hibbs 1984:43-44).

Vessel glass from Cathlapotle, Meier, and Fort Vancouver was analyzed using the methods developed by Wilson and previously applied at Middle Village (Wilson et al. 2009). Glass analysis established the vessel's form, function, relative age, and whether glass had been intentionally modified. Glass tool and debitage analysis based on lithic macroscopic analytical techniques was used to determine manufacturing techniques, tool types, and functions. Additionally, these data were compared to previous analyses of lithics and trade goods at the study sites.

This methodology was used to explore a number of research questions about contact and colonization along the Lower Columbian River. These included: Was vessel glass used to create tools by different groups? If so, how did the practice or way glass tools were created compare to how lithic tools were produced? What type of activities 
was carried out with these tools? Were glass tools similar in function to traditional lithic tool technology or were they something completely new? Why was glass chosen to create tools? Was this because of glass' material properties, abundance, or as the result of culture change, continuity, or creolization? Do the methods by which glass tools were created and glass tool functions vary between Chinookan sites and over time to the later Fort Vancouver Village community?

The answers to these questions, gained through the analysis of a rather insignificant item - vessel glass, provides a broader picture to how several groups of Chinookans dealt with colonization and the introduction of new goods. Additionally, for both Chinookans and later inhabitants of the Fort Vancouver Village this study illustrates the complex role of glass within power relations between colonizers and colonized.

This thesis is divided into six parts:

- Chapter 2 provides the broader historical background for the contact period along the lower Columbia River. Also included within this chapter is a discussion of Chinookan stone tool production and technology, types of vessel glass available during this period, and metal tools and firearms which were also available for use.

- Chapter 3 delivers background on the four sites of Middle Village, Cathlapotle, Meier, and the HBC Employee Village; and contains a summary of previous archaeological research, site components, and formation processes. 
- Chapter 4 provides the theoretical background of this study, a review of modified glass studies, and the study's hypotheses and their test implications.

- In Chapter 5, this thesis' methodology is presented, which includes general vessel glass, glass tool and debitage analytical procedures.

- Chapter 6 summarizes the results of the analysis; and lastly

- Chapter 7 discusses these results as they pertain to the research hypotheses, and provides overall conclusions, study limitations, and avenues for future work. 


\section{Chapter 2: Historical Background}

The history of contact and colonization along the Columbia River has been extensively written about in regard to Chinookan peoples (Hussey n.d.(a); Ruby and Brown 1976; Hajda 1984; Boyd 1999, 2011; Smith 2004; Sobel 2004; Wilson et al. 2009; Ames et al. 2011; Ames and Sobel 2013; Boyd 2013; Hajda 2013; Hajda and Sobel 2013; Lang 2013; Suttles and Lang 2013) and later fur traders at the HBC Fort Vancouver (Hussey n.d.(b), 1957, 1972, 1977; Kardas 1970; Erigero 1992; Burley 1997; Cromwell 2006). A complete discussion of this subject is beyond the purview of this work, and as a result this chapter's historical background is limited in scope. Subjects touched upon include: the Chinookan people and their tool technology; trade relations during the period of contact and colonization; trade goods, particularly with regard to bottles and their contents; and lastly the effects of contact on Chinookans.

\section{The Chinookan People}

Our knowledge of the Chinookan people prior to contact is based on archaeology and ethnographies. The term Chinook came from a village close to the mouth of the Columbia River. Over time the designation of Chinook came to define the Chinookan language family, which is comprised of Upper and Lower Chinookan groups (Hajda 1984:9-10, 64-65; Silverstein 1990:533). Cultural differences between these two groups included: household size, house and canoe forms, adornment and clothing, burial practices, and seasonal mobility patterns. Even so, group boundaries were fluid; and 
groups commonly intermarried, traded with each other, and shared the same harvest sites (Hajda 1984:133-150).

The Chinookan people are what is known as complex hunter-gathers. Huntergathers rely on non-domesticated plants and animals for subsistence. However, as complex hunter-gathers they have social structures and cultural traditions similar in complexity to many agricultural communities. Rich and diverse natural resources were collected in bulk by both free individuals and slave labor so that a large quantity could be stored for the winter. While dense populations of people, who were socially stratified by wealth and ascribed status, were maintained in semi-permanent villages centered around the plankhouse (Figure 2) (Hajda 1984, 2013; Ames 1994, 2001, 2002, 2004; Ames and Maschner 1999; Ames et al. 1992, 1999; Ames and Sobel 2013).

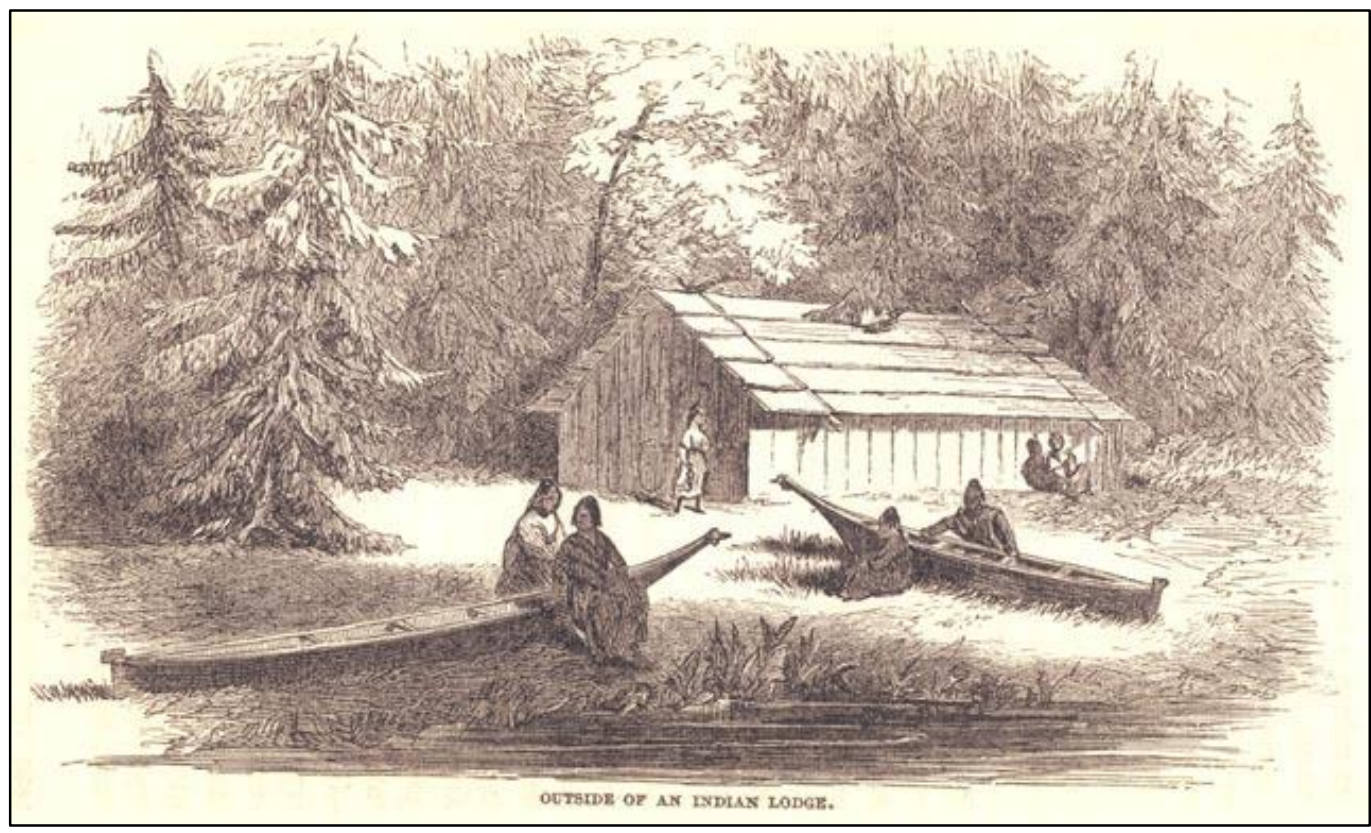

FIGURE 2. Etching by James Swan, ca. 1850s, of a Chinookan Plankhouse 


\section{Chinookan Tool Technology}

In order to place glass tools within the regional tool complex, the lithic technology of the Lower Columbia is discussed in this section. Flaked stone tools were created through a three stage reduction sequence as described by Smith (2004:120-122; 2009:259-260). Raw material was reduced by striking a core with a freehand hammerstone greater than $10 \mathrm{~cm}$ (3.93 in.) in dimension. Alternatively, bipolar reduction was used where a core was placed on top of an anvil rock and struck by a large hammerstone. These actions created debitage greater than $1.27 \mathrm{~cm}(0.5 \mathrm{in}$.$) in maximum$ dimension. Flaked material was further modified by striking it with a smaller hammerstone ( $<8 \mathrm{~cm}$ or $3.15 \mathrm{in}$.) or by pressure flaking with a softer material such as wood, bone, or antler. Material reduced with a small hammerstone was usually further modified using pressure flaking. The use of a small hammerstone or pressure flaker created debitage less than $1.27 \mathrm{~cm}(0.5$ in.) in maximum dimension.

Lithic tools created by these techniques were dominated by a variety of low energy (expedient) tools that are utilitarian in form. Smith (2009:258) characterizes these expedient tools as "minimally shaped, mundane flakes used for a variety of scraping, shaving, and woodworking tasks". These tools were used for a single function and rarely reused (Hamilton 1994:112-113, 115; Smith 2004:174; Wilson et al 2009:258).

Additionally present, are high energy, curated tools (also known as formal tools), which are more time extensive to produce. These include projectile points, hide scrapers, and a variety of pecked and ground stone tools (Wilson et al. 2009:257-258) Hamilton (1994: 
149-160) provides a useful description of common flaked tools types, which is summarized in Table 1.

TABLE 1. Lower Columbia Tool Types (Based On Hamilton 1994).

\begin{tabular}{ll}
\hline Tool Type & Characteristics \\
Projectile Point & $\begin{array}{l}\text { Variety of types including: contracting stem, expanding stem, corner } \\
\text { notch, side notch, chevron, and stylized (Based on Pettigrew's 1981 } \\
\text { classification). }\end{array}$ \\
\hline Knife & $\begin{array}{l}\text { Bifacially flaked tools, with a strong working edge. Some have } \\
\text { incorporated handle or hafting elements. }\end{array}$ \\
\hline Graver & $\begin{array}{l}\text { Sharp, strong point with an obtuse edge angle greater than } 90^{\circ} \text {. The } \\
\text { point is less elongated than perforators in order to give it more } \\
\text { strength. }\end{array}$ \\
\hline Perforator & $\begin{array}{l}\text { Point which is more delicate and elongated than gravers. Bits can be } \\
\text { sharp or blunt, and are bifacial, triangular, or round in shape. }\end{array}$ \\
\hline Handles are opportunistic or manufactured "T", "L" or "I" shaped. \\
\hline Scraper & $\begin{array}{l}\text { Unifacially flaked tool with relatively straight to convex margins, } \\
\text { and edge angles of } 60^{\circ} \text { and greater. Both hafted and hand held. }\end{array}$ \\
\hline Cutter & $\begin{array}{l}\text { Unifacially flaked tools with long, straight to concave edge margins, } \\
\text { and edge angles ranging from } 30 \text { to } 60^{\circ} .\end{array}$ \\
\hline Saw & $\begin{array}{l}\text { Unshaped, unifacial or bifacial tools with straight edge margins and } \\
\text { edge angles less than } 30^{\circ} \text {. Most often not retouched. }\end{array}$ \\
\hline Wedge & $\begin{array}{l}\text { Bifacially flaked with broader edge angles for heavy duty cutting. } \\
\text { Flat, strong bits that are rectangular in form with an increasing edge } \\
\text { angle from the wedge tip to body. }\end{array}$ \\
\hline
\end{tabular}

A number of studies of lithic technology at Chinookan sites have been done. The results of these are summarized briefly. Hamilton's (1994:120-123) study at Meier found that stone was stockpiled. This allowed for the wasteful use of stone, characterized by expedient tools with little reuse. Only specialized tools, such as projectile points and hide 
scrapers, were curated. This may be a consequence of the need for reliable tools (sensu Bleed 1986) for certain tasks.

Smith's (2006:180) usewear study of the lithic technology at Cathlapotle and Meier found that tools were most often used to work antler, bone, hide, flesh, and wood, but not vegetal matter. Congruent to earlier findings by Hamilton (1994) at Meier, Smith (2004:174) found that Cathlapotle also had a "wasteful expedience rather than conservative recycling and reuse" of tools. Smith (2004:175) as well as Sobel (2004:820) found that Cathlapotle had a larger amount of tools used for hide working than Meier.

Davis' (2010) analysis of projectile points at Cathlapotle and Meier found that small stemmed projectile points were the most common type found at Meier, while side notched projectile points dominated Cathlapotle's assemblage. Additionally, at Cathlapotle there was some variation in types of projectile points produced between houses. Within house segment 1D side notched projectile points were the most common, in house segment $1 \mathrm{C}$ side and basal notched projectile points dominated, and in house segment 1B foliate points occurred most frequently. In houses 4 and 6 short stemmed points made up the majority. At Meier, the only evidence of variability is that foliate points were concentrated within the south end of the plankhouse (Ames, Personal Communication 2014).

Sobel $(2004,2011)$ analyzed the obsidian from Cathlapotle and Meier. Obsidian, which is physically similar to glass, has several advantages over other stone raw material. It does not need to be heat treated before being worked and has a sharper edge than other 
types of stone as well as antler and metal. However, obsidian is brittle and consequently has a shorter use-life. Additionally at Cathlapotle and Meier, obsidian did not occur locally, so it was more costly to acquire than local stone (Sobel 2004:303).

Obsidian from Cathlapotle and Meier predominately came from sources west of the Cascade Mountains (Sobel 2004:632, 2011:16). Obsidian tools made up a small percentage of all stone tools with $6 \%$ at Cathlapotle and $4 \%$ at Meier. The most common obsidian tool type was projectile points. Though obsidian projectile points only made up a small portion of all stone projectile points at the two sites. At Cathlapotle $10 \%$ of all projectile points were obsidian, while at Meier, 5\% were obsidian (Sobel 2011: 10, table 3).

Sobel (2004: 302, 816-817) found that ownership of obsidian raw material was associated with higher status households, who also produced obsidian tools more extensively than lower status households. However, it is unclear whether obsidian tools themselves operated as prestige items. This is because most obsidian tools such as projectile points or bifaces were common utilitarian objects, and were found in contexts with tools made of locally sourced stone.

\section{European Exploration and Contact}

Even before Northwest Coast Indians first met face to face with Spanish, Russians, British, and American explorers in the late $18^{\text {th }}$ century they were already experiencing the effects of contact (Sobel 2004:103-105; Boyd 2011:7). Smallpox epidemics likely reached the Chinookan people somewhere between the 1770 s and the 
early 1780s (Boyd 1999:32, 2013:236). By the mid-1700s neighboring Plateau and Great Basin Tribes had horses, which allowed them to expand their trade network to peoples of the lower Columbia (Stern 1998:645). As a result, the Chinookans may have acquired European goods from these tribes (Sobel 2004:104-105). Also, oral histories, historical accounts, and archaeology indicate that shipwrecks, as well as wreckage and material goods periodically made it to the coast and the mouth of the Columbia River (Gibbs 1877:237; Boaz 1894:277; Ruby and Brown 1976:24-31; Plummer 1991; Cromwell 2010:17, 23-24, 33; Boyd 2011:7).

The first documented contact occurred in May 1792, when the American trader Captain Robert Gray explored the Columbia River's mouth and estuary in the brig Columbia Rediviva. After British explorer Captain George Vancouver heard that an American had discovered a large river and the fabled Northwest Passage, Lieutenant William Broughton was sent in the autumn of 1792 to explore the river and establish the British Empire's claim. Broughton anchored the HMS Chatham at the mouth of the Columbia River, where he encountered the British merchant ship Jenny commanded by James Baker (Kardas 1971:22; Schwantes 1996:50-51; Wilson et al. 2009:11). The presence of the Jenny within the Columbia possibly indicates that British traders had already started trading with the Chinook near the river's mouth (Elliott 1915:4). Afterward traders, explorers, missionaries, and ultimately settlers flowed into the region (Schwantes 1996). 


\section{The Fur Trade}

There was a strong tradition of trade among Pacific Northwest Native Americans even before Europeans and Americans started trading goods. Gibson (1992:8) writes that "trade was well suited to Northwest Coast Indian Society, for one of its main values and goals was the accumulation, display, and redistribution of material goods". The Chinookan people seem to have taken on the role of middle man, trading goods from one area with goods from another (Gibson 1992:10-11; Boyd 2011:14-15; Hajda and Sobel 2013).

The early fur trade in the Pacific Northwest was dominated by American traders and centered primarily on the trade of otter pelts, though land animals such as beaver were also sought after ${ }^{1}$. Trading vessels anchored along the coastline and traded with Native Peoples for a variety of objects including: metal, cloth, muskets, molasses, bread, alcohol, mirrors, beads, buttons, tobacco, and other items. There are even accounts of Native American slaves being traded by Anglo Americans. Otter and to a lesser extent beaver were shipped to China where they were traded for silks, tea, woodwork, and porcelains. In turn these items were sold to markets in America and Europe (Gibson 1992:9-11, 25-35, 205-206, 214-228, 233-239; Boyd 2011:14-15).

Sea otters were not particularly plentiful in the region around the mouth of the Columbia. However, there was a great demand for clamons ${ }^{2}$ (Figure 3), elk hide armor,

\footnotetext{
${ }^{1}$ Otter furs were favored by Chinese in the Northern Provinces, while in the warmer southern areas beaver fur was preferred (Gibson 1992:54).

${ }^{2}$ Clamons were known by a variety of terms including: clammels, clemmels, clemens, clemals, and clamels (Gibson 1992: 230).
} 


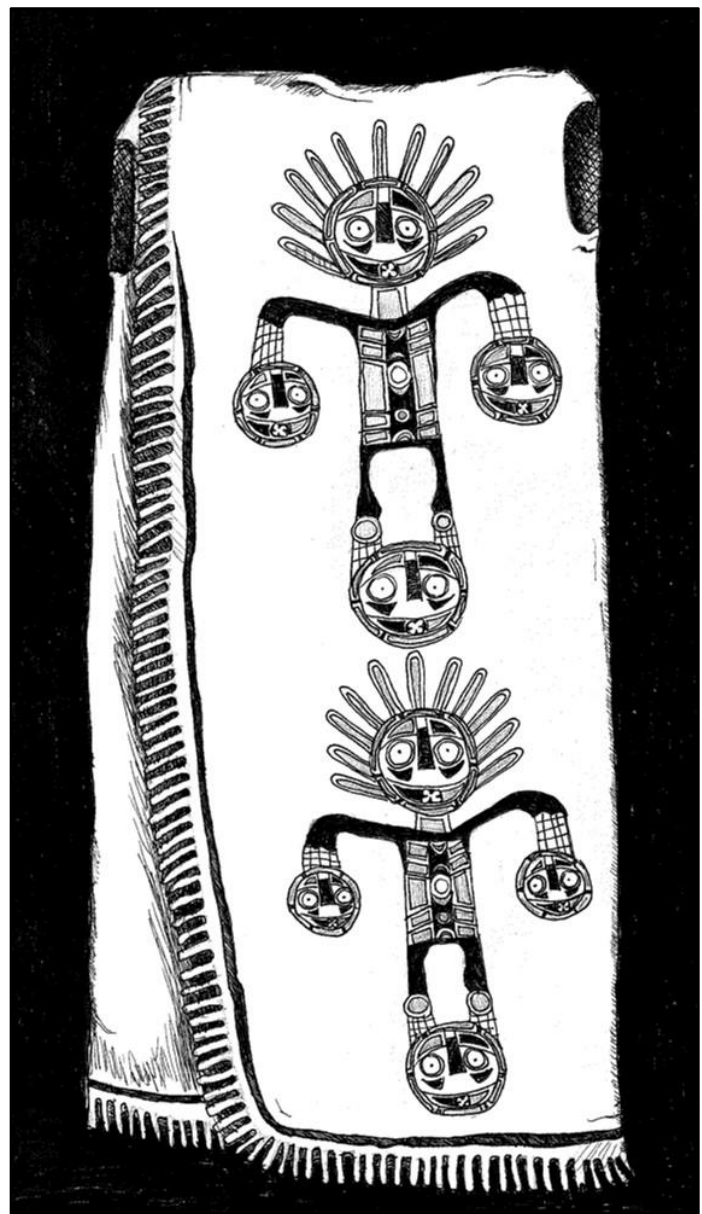

FIGURE 3. Clamon, Elk Hide Armor with Chinookan Style Figures (author image) which were produced in the lower Columbia and the Willamette Valley (Ross 1849: 89; Elliott 1927:278-279; Ruby and Brown 1976: 59-72; Gibson 1992:9, 230-231; Boyd 2011:12, 14). As a result, the Columbia soon became an important part of the larger trade network. Now fur traders exchanged trade goods with the Chinookans for clamons, and these clamons were traded to northern groups, such as the Nootka and Tlingit (located in modern day British Columbia) and Haida (located in modern day British Columbia into Southeast Alaska), for otter pelts. The Chinookan people took these trade goods and exchanged them for resources with inland and upriver groups (Gibson 1992: 8-10, 230-231; Mallory 1998:31; Boyd 2011:14-15).

These early maritime fur traders were much more dependent on Native Peoples than Native Americans were on the traders. Not only did the traders have to hope that Native Peoples wanted the goods that they had hauled half way around the world; but they also relied on them to provide water and fresh foods such as edible plants, meat, and fish. Historic accounts are full of traders complaining about the changing demands in 
regard to types and amounts of goods (Cole and Darling 1990:123-124; Gibson 1992:204-228, 242-247; Mackie 1997:30,131,153).

In 1811, the fur trade along the Columbia changed with the establishment of Fort Astoria, the region's first land fort. The Pacific Fur Company, an American firm, established Fort Astoria on the south side of the Columbia, near the river's mouth (Mackie 1997:13-14; Boyd 2011:35). Numerous problems plagued the Pacific Fur Company (Franchère 1967:80-85; Mackie 1997:15-16), and in 1813, Fort Astoria was sold to the Montreal based Northwest Company, who renamed it Fort George. Then in 1821 the Northwest Fur Company and the HBC merged, which virtually put the Pacific Northwest fur trade in British control (Mackie 1997:17-20, 29-32, 38). The reorganized HBC closed Fort George in 1825, and moved its' regional headquarters to the newly established Fort Vancouver (established in 1824) located at present day Vancouver, Washington. This new location strengthened British claims to the lands north of the Columbia, and provided room for large scale agricultural endeavors (Erigero 1992:12$13)$.

Some Native groups adapted to these new inland forts by settling around them. This put groups, such as the Chinookans, in a strategic location to act as middlemen between the fur traders and outside Native Peoples (Cole and Darling 1990:125). Alexander Ross (1849:77) of the Pacific Fur Company and later the Northwest Fur Company, complained that the Chinook "formented and nourished the misunderstanding between us and the distant tribes," and by this means "monopolizing all the trade 
themselves". The Chinook were able to buy furs from neighboring tribes and sell them to the Astorians at twice the price (Ross 1849:77).

After Fort Vancouver was established, some of the local area Chinookans traded directly at the fort, or became employees of the HBC — a few journeying with fur brigades to trap fur in the region. In addition, some Chinookan women married HBC employees (Erigero 1992:56, 64-65; Mackie 1997:33; Lang 2013:266, 269).

Dwindling fur resources from over hunting led to an increase in competition between maritime and land based traders for these resources. At the same time, landbased traders of Fort Astoria and the later Fort Vancouver struggled with supplies (Gibson 1992:63-70). Fort Astoria fur trader Alexander Ross (1849:154) complained that trade goods were subpar and not items that the Natives would want. Goods being shipped to Fort Vancouver during the early years more often than not arrived late and were sometimes broken. Worse yet, whole supply ships occasionally wrecked on the dangerous Columbia bar (Gibson 1992: 69-70). These factors affected the fur trader's ability to successfully make deals, as well as what trade goods were available for trade.

Indigenous Peoples sometimes used the increase in competition between traders to play them off each other for better trade terms or goods (Gibson 1992:63, 75). However, Native Peoples should not be interpreted as holding most of the power in trade relations. Maritime fur traders sometimes used violence to acquire furs. Leaders of different native groups were taken hostage and then exchanged for furs, and in at least one instance pelts were taken at gunpoint (Gibson 1992:158,160-161; Mallory 1998:48, 
52). Additionally, trade goods such as foodstuffs and alcohol became incorporated into Native Culture over time. As a result, these types of goods were greatly desired — and traders could still make deals to their advantage (Gibson 1992:225-227).

The otter population eventually became depleted from overhunting, and trade shifted to beaver and other land animal pelts (Gibson 1992:240-241; Mackie 1997:28). This beaver fur was felted, and used to create sturdy high quality hats that were desired in Europe (Crean 1962:375). American fur trading ships came to the coast less and less, until the HBC became the dominant fur trade entity in the region (Gibson 1992:79-80; Mackie 1997:145-146).

\section{Chinookan People and Fur Trader Relationships}

It is impossible here to discuss in any detail the complexity of relationships between fur traders and Native Peoples; and several scholars have already provided nuanced analyses (Gibson 1992; Vibert 1997; Jetté 2006/2007; Whaley 2007; Bergmann 2008; Lang 2013). In general, cultural misunderstandings and prejudices were widespread (Ronda 1984: 178-179; Gibson 1992:153-157, 277; Lang 2013:251). Fur traders often portrayed the Chinookans and other native groups as 'deceitful and lazy', who took advantage of the 'honest, hardworking fur traders' (Ross 1849: 77-78, 80; Merk 1968: 74, 94-95; Gibson 1992: 153-155, 157,159, 277; Mackie 1997: 81, 100-101). Both fur traders and explorers failed to understand territorial rights to waterways, land, and resources, as well as how trade was traditionally carried out in the region (Ronda 1984:172; Gibson 1992:156; Jetté 2006/2007:9). When items were taken, fur traders 
interpreted such actions as theft, rather than Chinookan peoples claiming what was owed to them (Ronda 1984:172).

Prejudice could also lead to violence. As mentioned above, fur traders sometimes took pelts by force. In other cases, villages were destroyed and Native Peoples massacred for no apparent reason. Violence by either fur traders or Native Peoples was returned with more violence by the other side. Often this reprisal was unintentionally taken on a group not involved in the original incident; and the cycle of violence and retribution continued anew (Gibson 1992:153-172). Unsurprisingly, paranoia of being attacked was prevalent even when there was no apparent threat (Mallory 1992:57). For example, in July of 1812 , the Astorians, without any type of known threat, were on high alert against an attack and were performing military drills within the stockade. Some Chinookans who were there became alarmed and left right away. For the Astorians this supported their "belief that they [the Chinookans] are not friendly disposed towards us, and are conscious of having either a desire to harm us or have already concerted measures to that effect" (Jones 1999:102). As the editor of the Annals of Astoria points out, the Chinookans were probably at the fort simply for trading and were justifiably alarmed by such a show of force (Jones 1999:102-103, foot note 40).

\section{Creation of New Multicultural Communities}

Those Chinookan people, who worked at Fort Vancouver or were married to trappers, lived with most other $\mathrm{HBC}$ employees in a village outside the main fort stockade (Figure 4) (Kardas 1971:167,198,213; Erigero 1992:93). Occupied between 1825 and 1860, the Employee Village was the largest multiethnic community on the 
Pacific Coast (Mullaley 2011:1). These villagers were made up of the HBC servant class that included men of French Canadian, Anglo Saxon, Iroquois, Hawaiian, local Native American, and Métis descent (Ross 1976:6). The Métis were most often the children of fur trappers (of French Canadian, English, and Scottish backgrounds) and Native American women (Burley et al. 1992:14; Burley 2000:28; Mullaley 2011:17; Wynia 2013:28).

As mentioned earlier, some employees entered into informal marriages with Native Women from a variety of native groups, including Chinookans (Kardas 1971:167, 210; Mullaley 2011:18). For the Chinookan peoples and other groups there was an advantage of marrying one's daughter to these men, since it expanded one's sphere of resources and created political alliances (Hajda 1984:195,240; Bergmann 2008:37-38). These new alliances were also beneficial to fur traders since native women provided valuable labor as well as expertise (Whaley 2007:680). 


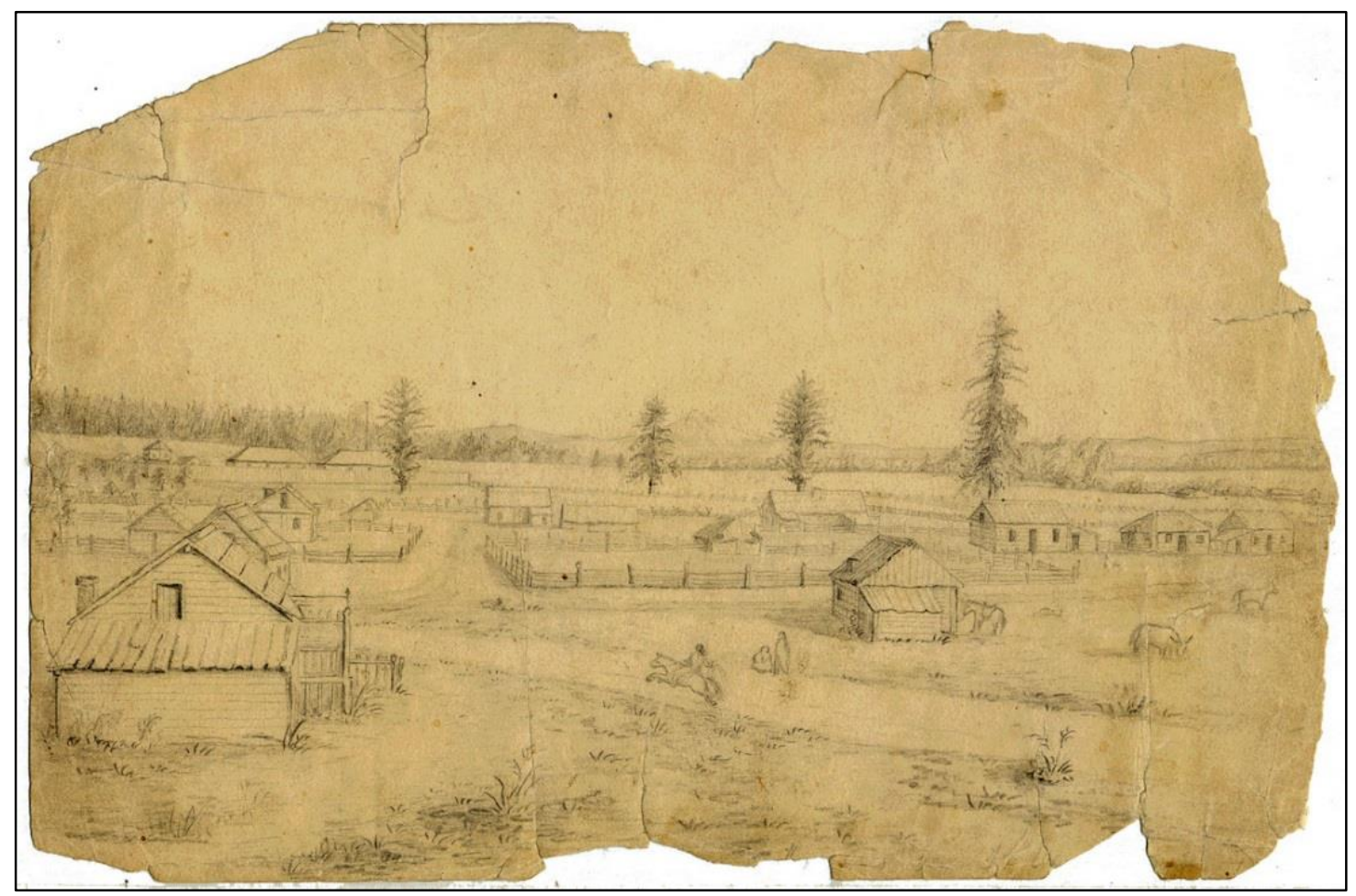

FIGURE 4. George Gibb's 1851 Sketch of the Fort Vancouver Employee Village (Courtesy of Fort Vancouver National Historic Site)

\section{Fur Trade Goods}

As mentioned above, a variety of goods were shipped to the Northwest Coast to trade with the indigenous population for provisions, native-made products, and pelts. Important to this discussion are products contained in glass bottles and other glassware items which could be used to create tools. Additionally, this section covers metal projectile points, knifes, and guns which might have been used in place of stone and glass tools.

\section{$\underline{\text { Alcohol }}$}

Before contact there were no intoxicating substances similar to alcohol on the Northwest Coast. Alcohol was introduced by shipmasters with the assumption that 
intoxicated Natives would be more willing to trade and on less favorable terms (Gibson 1992:225). At the beginning, Native Peoples had little taste for it. However, over time, rum in particular, became very popular (Cole and Darling 1990:122; Gibson 1992:225). By the 1820s, Chinookans came to expect it in trade (Hajda 1984: 272); and a HBC standard of trade for Fort George during the period of 1824 to 1825 lists one bottle of 1/3 parts rum to be exchanged for one large, prime beaver pelt (Merk 1968:173). Alcohol was also used to pay Chinookans and other Native Peoples to act as pilots for ships traveling the Columbia (Wuerch 1979:114).

The main advantage of rum and ethyl alcohol was that they were cheap and less expensive than many trade goods. Alcohol was made even cheaper by dilution with water (Gibson 1992:226; Frank et al. 2000:349). Indian Rum or grog, as it was known, was made up of $3 / 8$ to $1 / 2$ parts rum and the remainder water (Gibson 1992:225-226). Nevertheless, it should not be assumed that this watered down rum did not have a high alcohol content. The rum shipped to Fort Vancouver was from 180 to 190 proof, roughly equivalent to 90 to $95 \%$ alcohol before it was watered down (Ross 1976: 789).

Rum and other beverages in general were shipped and stored by the HBC in kegs, hogsheads, and glass and ceramic bottles (Ross 1976: 778-779). Other trading outfits probably transported beverages in similar manners. Additionally, given that rum was shipped essentially in concentrate, it seems likely that it was shipped in hogsheads and kegs, then diluted and bottled before trade. 
The HBC imported a variety of different alcohols for purchase by its employees. These included: ale, beer, porter, stout, wine, rum, brandy, and gin (Ross 1976:780-789). A distillery was even operated at Fort Vancouver at various times. Reportedly, this distillery was closed sometime in the 1830s because of problems caused with alcohol consumption (Mackie 1997:186). However, an 1841 inventory of goods on hand lists 13 gallons of locally made whiskey (Hussey 1972:272), while in an 1847 inventory, a 132 x $18 \mathrm{ft}$. distillery is listed at the fort (Elliott 1931:34).

Although Fort employees were allowed to purchase alcohol, its' price was raised to discourage demand by company servants (Rich 1941:79; Ross 1976: 1352). In an 1829 letter to the HBC Governor and Committee, Chief Factor McLoughlin (Rich 1941:79) states that servants are charged for alcohol 18 shillings per gallon, a price which was set "to prevent too great a demand". In today's currency, this would be roughly equivalent to 72 dollars per gallon or 9 dollars a pint (http://www.nationalarchives.gov.uk/currency/). Additionally, there was an annual limit on alcohol allowed per individual (Ross 1976: 779). By 1840 it seems that the company's servants were no longer sold alcohol. Though evidently they were still provided "the usual Gratuity, a pint Rum on engaging, one pint at New Year's day, and pint when they leave for their winter quarters on a long voyage, and a pint when they return, and now and then a glass" (Rich 1943:71-72). McLoughlin noted that this handout was part of the long established custom at the fur forts (Rich 1943:72). During Charles Wilke's stay at Fort Vancouver in 1841 he relates how McLoughlin purchased all the goods of the brig Thomas H. Perkins in order to get ahold of a large amount of rum, so it would not be sold 
in the region. Instead, McLoughlin planned to store it with the large quantity of alcohol already in the fort's magazine (Wilke 1845:330). It is not clear whether this alcohol was to be kept away from Native Peoples, or from HBC servants, or both. If McLoughlin was so concerned about alcohol, it would have been more prudent to destroy it rather than stockpile such a large amount.

The HBC discouraged the trade of ethyl alcohol to Pacific Northwest Native Americans for both moral and pragmatic reasons (Dunn 1844:246; Rich 1943:29; Mackie 1997:181). In terms of the latter, liquor was blamed for making the Indigenous population more likely to fight and less so to hunt (Gibson 1992:225), or in the case of Chinookan peoples they would not be able to barter for furs with surrounding groups (Merk 1968: 109-110). The British fur traders held the Americans and Russians responsible for the importation and sale of large quantities of ethyl alcohol to Native Peoples (Merk 1968: 330; Mackie 1997:55,112-113,140,181). This is probably not an accurate assessment of the situation. Although alcohol is not listed on the inventory of items sold at the Indian Trade Store at Fort Vancouver (Hussey 1976), the HBC still traded alcohol in order to compete with the American and Russian traders (Rich 1941: lxxxviii, 1943:56, foot note 4; Gibson 1992:225-226; Mackie 1997:342, end note 46).

After the departure of the Americans from the area's fur trade in 1842, the HBC and their Russian fur trade counterpart, the Russian American Company agreed to ban the trading of alcohol (Rich 1943:72, foot note 1; Gibson 1992:226; Mackie 1997:181). This prohibition did not last long. Both groups were soon back to trading alcohol, wreaking havoc on Native American groups (Gibson 1992:226). 


\section{Other Bottled Products}

Of course not all glass bottles at this time contained alcohol, and may instead have contained foodstuffs and medicines. Unfortunately, historical and ethnographic accounts are mostly silent with regard to these as fur trade items.

One such food item that was recorded as being much in demand among Native Peoples during the entire fur trade period was molasses. Like rum, molasses was also watered down to reduce its price (Gibson 1992:160). Molasses seems to have sometimes been shipped in hogsheads (63 gallon barrels) (Furgerson 1810:15-20), and distributed in buckets (Gibson 1992:160, 227), as well as bottles (Jackman 1978:57).

At Fort Vancouver, a variety of foodstuffs were recorded as being bottled, and some employees may have had some access to them. These foodstuffs included lime juice, Durham mustard, olive oil, vinegar, and pickles (Ross 1976: 791-792). These items were not recorded as being traded at the Indian Trade Shop at Fort Vancouver, but fur traders in historical accounts were often willing to trade whatever was necessary to make a deal (Gibson 1992:29).

Bottled medicines were another item that were shipped to Fort Vancouver, and Hussey (1976:103-109) provides an extensive list of products imported. The dispensary at Fort Vancouver was situated next to the Indian Trade Store (as the post surgeon was responsible for both trade and medicine) (Hussey 1976: 68), and it is possible that some medicines were traded for furs and other provisions. 


\section{Glasswares}

Mirrors or looking glasses as they were called in this period were imported for trade (Rich 1941:82, foot note 1; Gibson 1992:215). Unfortunately, no additional information on these trade goods was located during research.

A variety of glass tablewares were likely available for trade. In a letter dated 28 September 1828, George Simpson suggests to Chief Factor John McLoughlin that “a small assortment of glass and crockery ware would find a ready sale among these Indians" (Rich 1941:82, foot note 1). The predominate glassware shipped to Fort Vancouver were a variety of wine glass styles and tumblers in different sizes. Also sent to a lesser extent were decorative tablewares, including decanters, salt cellars, and sweet meat dishes (Ross 1976: 543, 547). How available any of these glassware products were to Chinookans and residents of the Employee Village at Fort Vancouver is unclear.

\section{$\underline{\text { Metal Tools and Firearms }}$}

Metal was familiar to native societies in the Northwest before contact. Native sources of metals, including copper and iron were available (Jackman 1978:79-80; Jopling 1989:45-46, 50, 52; Banach 2002); and shipwrecks may have occasionally brought foreign metal to the coast (Hajda and Sobel 2013:109). Even so, early fur traders found that there was quite a demand for metal items (Gibson 1992:217). Sobel (2004: 200) postulates that this great demand for metal indicates that it was considered a form of wealth before contact. 
Historical records seem to suggest that during the early fur trade, iron, particularly wrought, was in high demand among Northwest Coast Peoples. This is thought to be the result of iron being better suited than other metals for making weapons such as projectile points (Gibson 1992:217-218). Iron projectile points are present at Cathlapotle, Meier, and Middle Village (Smith 2009:268); and at Fort Astoria, Native Peoples regularly brought bar iron to be made into arrowheads by the blacksmith (Ronda 1990:212). The presence of relatively large quantities of copper at Cathlapotle and Meier (Banach 2002), indicates that copper was also sought after.

In terms of metal tools, knives and axes appear to have had the greatest popularity (Sobel 2004:201). Other metal tools traded were canoe chisels, awls, files, and daggers (Hussey 1976:91-98: Mackie 1997:224). These types of metal tools and others, such as saws and scissors, were available to the HBC employees at Fort Vancouver (Hussey 1972:192-207).

Historical records indicate that the market was quickly flooded by metal items, decreasing demand (Gibson 1992:219). In 1793, one ship captain complained that the Chinook at the mouth of the Columbia would not trade for metal (Gibson 199:219). By 1795 there was a general decline in the value of metal, which continued until the 1850 s (Sobel 2004: 200). Even so, metal tools were kept well in stock at the Fort Vancouver Indian Trade Shop (Hussey 1976:91-98), which points to some demand.

Firearms were a popular trade item throughout the fur trade (Gibson 1992: 222223). Lewis and Clark found that the Chinook at the mouth of the Columbia already had 
muskets in 1805, although they were older American and British models not in the best of shape (Moulton 1990[6]: 15, 61-62, 205). By the early 1820 s, approximately $1 / 3$ of all sea otters traded by Americans were for guns (Gibson 1992: 222).

Despite the popularity of firearms, the HBC's policy was to keep them at high prices. In 1829, McLoughlin noted this was done because the Chinookans "are no animal hunters and guns are of little use to them in procuring food" (Barker 1948:23-24); although his real concern may have been a general lack of guns to trade that year (Barker 1948:24). Alternatively, it is possible that the HBC was afraid that the native population would become well-armed. This is suggested by the restriction of how much ammunition could be purchased starting in the 1830s (Hussey 1976:59). In any case, a variety of guns, ammunition, powder, flints, and gun worms were all sold at Fort Vancouver's Indian Trade Shop (Hussey 1976: 91-98).

Firearms may have been valued by Chinookans for their use in hunting and warfare (Wilson et al. 2009:404). Yet, their greatest value was probably as items of wealth and status (Gibson 1992:222; Sobel 2004:199; Wilson et al 2009:371, 404).

Archaeologically, there is limited evidence of firearms at Meier and Cathlapotle (Ames and Sobel 2013:144), while at Middle Village, guns parts, flint, and ball and shot were recovered (Wilson et al. 2009: 366-372). This lack of gun related material has been interpreted as indicating that firearms had little effect on hunting post contact (Ames and Sobel 2013:144). 
Additional archaeological and historical research is needed on metal tools and firearms to better understand how these items fit into post contact Chinookan Society.

\section{The Impact of Contact and Colonization}

The impact of contact and colonization on Northwest Coast Native Groups is much debated. Some anthropologists and historians have argued that impacts were relatively limited (Cole and Darling 1990; Acheson and Delgado 2004). In this view, the main changes to Native society were the introduction of new goods, which allowed those individuals with greater power in villages to gain even more power. Additionally, Native economies went from being primarily subsistence based, to focusing on procuring furs for trade (Cole and Darling 1990:130-131). Critics of this viewpoint argue that it fails to take account of introduced foreign diseases (Wilson et al. 2009:386), of which malaria epidemics alone during the 1830s killed around 88\% of the population (Boyd 1999:84). Nor are the impacts of colonialism addressed (Wilson et al. 2009:387).

Recent archaeological studies have been able to provide important new details about how Lower Columbia Chinookan lifeways changed post contact. These include:

- Intensification in the trade of obsidian, but shrinking of trade network size (Sobel 2011).

- Lower ranked individuals controlling access to Euro American manufactured goods (Sobel 2004:409-530; Sobel 2011:159-199). They were able to access these goods since fur traders did not restrict themselves to only trading with higher ranked individuals (Hajda and Sobel 2013:111, 123). 
- Copper at Cathlapotle and Meier was from foreign sources, and before contact native copper may have been rare in the Lower Columbia (Ames et al. 2011:3536)

- Isotopic analysis of dog bones indicates that riverine and marine resources remained an important part of the diet after contact (Ames et al. 2011:33-34).

- Decreasing hearth size and an increasing number of hearths, placed on the house floor (rather than in hearth boxes), may reflect depopulation from disease epidemics. Survivors of these epidemics possibly formed new groups in order support household production, which in turn led to multiple unrelated groups sharing a plankhouse (Gardner-O'Kearny 2010).

- At Cathlapotle lithic hide scrapers increase, perhaps in order to produce clamons for trade (Smith 2006:139; Ames et al. 2011:39).

- At Meier, the bone tool assemblage suggests an increase in woodworking (Fuld 2012), maybe to create items for native consumption (Ames et al. 2011:42)

This thesis through the analysis of flaked glass attempts to add to this knowledge of Chinookan post contact society; and the following chapter provides background on the archaeological sites used in this study. 


\section{Chapter 3: History and Archaeology of the Study Sites}

This chapter discusses the four archaeological sites explored in this study; including their history, archaeology, previous research, and site formation processes as they pertain to glass artifacts.

\section{Cathlapotle}

The village of Cathlapotle (45CL01) is located on the U.S. Fish and Wildlife's Ridgefield Wildlife Refuge near the confluence of the Columbia and Lewis Rivers. Archaeological work indicates that the site was occupied between AD 1450 and the mid1830s, and housed 900 to 1,400 people depending on the season (Ames et al. 2011). Cathlapotle was involved in the fur trade and is mentioned in several ethnohistoric accounts (Boyd 2011).

In 1792, Lt. William R. Broughton was sent by Captain George Vancouver on a launch to explore the newly discovered Columbia River. On October $28^{\text {th }}$, Broughton passed a Chinookan village which archaeologists and ethnohistorians believe was Cathlapotle (Ames et al. 1999:14; Boyd 2011:8-10). There canoes full of Chinookans rowed out to the Chatham, and small trinkets were exchanged and traded. Broughton then demonstrated his rifle to the startled Chinookans by shooting their clamon armor (Bell 1932:143-144; Vancouver 1984:755-757; Manby 1992: 199,323; Boyd 2011:10-13).

Cathlapotle was not mentioned again in historic accounts until Captain Merriweather Lewis and Lt. William Clark passed the settlement on their way down the 
Columbia in 1805 . On November $5^{\text {th }}$, Clark wrote that they passed a large village made up of 14 houses, and were met by a canoe full of Chinookans who wanted to trade. On their return trip east, Lewis and Clark stopped at Cathlapotle for several hours on March 29th, 1806. Lewis and Clark both wrote about the village, and described the inhabitants, houses, and the harvest of wapato (Moulton 1990[6]:23, 1990[7]:25-28, 30, $36)$.

Afterwards Cathlapotle is periodically mentioned in documents from Fort Astoria and Vancouver by fur traders (Wuerch 1979; Jones 1999; Boyd 2011). Sometime after 1830, Cathlapotle was abandoned (Ames et al. 1999:18). The region at this time was struck by a malaria epidemic, which wiped out much of the Chinookan population (Boyd 1999:84,242-245, 2011:71, 74, 83). Historical records suggest that the Cowlitz resettled or settled near Cathlapotle by at least 1836 (Ames et al. 1999:18; Boyd 2011:178-179). After the Cowlitz there is no evidence of other people living there and the land being used for agricultural purposes (Ames et al. 1999:18).

Cathlapotle was excavated between 1991 and 1996 as a field school for Portland State University under the direction of Kenneth M. Ames. Field work identified six plank houses, four of which were excavated along with associated features (Figure 5) (Ames et al. 1999:19, 23-34, 37). An additional house depression was discovered beneath one of the houses (Ames et al. 2008:5; Fuld 2012:28). These semi subterranean house structures ranged in size from 10 x $20 \mathrm{~m}$ to 15 x $70 \mathrm{~m}$ (Ames et al. 1999:39; Fuld 2012:28). Four of these houses were subdivided by interior walls into compartments, and House 1 had four compartments (Ames et al. 1999:19). These compartments may explain the discrepancy 
between Lewis and Clark's count of 14 houses and the number represented archaeologically (Sobel 2004:543). Two middens were located in between houses, and activity areas were located in front of the houses. These activity areas included: sheet middens (diffuse scatters of refuse), hearths, earth ovens, and pits. Inside the plankhouses were central hearths that ran the length of the house and wooden sleeping platforms/benches along the wall. Beneath these platforms, storage pits were dug into the earth. No planking was placed over the ground; instead there were clay soil floors in House 1 and a sand floor in House 4 (Ames et al. 1999; Smith 2004; Sobel 2004:557-560, $567)$.

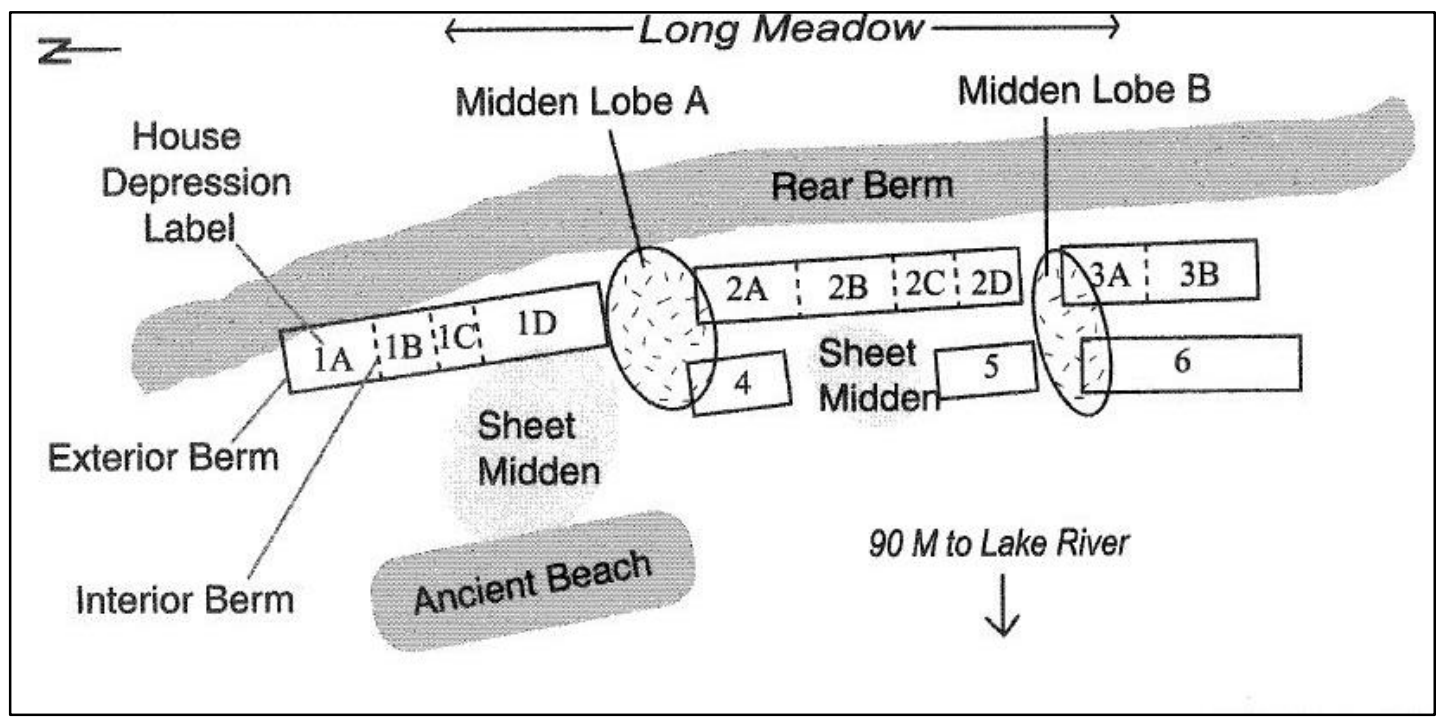

FIGURE 5. Site Map of Cathlapotle (Courtesy Of Kenneth Ames)

Numerous reports and articles have been written on the site of Cathlapotle (See Ames et al. 2011 for a summary). Additionally research has been done on many of the artifact assemblages. These include: social organization based on tool technology (Smith 2004); obsidian trade networks (Sobel 2004, 2012); the projectile point assemblage 
(Davis 2010); the bone and antler tool assemblage (Fuld 2012), faunal analysis (Butler 2002; Zehr 2002; Lyman 2003; Harpole 2006); hearth features (Gardner-O'Kearny 2010); the ceramic assemblage (Cromwell 2010); copper (Banach 2002); and trade beads (Kaehler 2002).

Archaeological sites are very rarely pristine, perfectly preserving the artifacts where they were deposited. Rather artifacts undergo a variety of processes before, during, and after they are deposited, all of which must be considered when interpreting the archaeological record (Schiffer 1987). Cathlapotle has been affected by numerous site formation processes, which Smith (2004) has explored. During Cathlapotle's long occupation, daily house maintenance activities moved artifacts around. These included cleaning debris from floors, within storage pits and hearths, and re-depositing material outside in middens. Some artifacts would have become lost in artifact traps such as those underneath benches, in storage pits and hearths, or even loose floor matrix. Although Cathlapotle was not a seasonal settlement, it is possible that under some circumstances, such as flooding or trips to gather resources elsewhere, inhabitants left these settlements for periods of time (Smith 2004:36-37; 42-53). One historic account describes plankhouse planking being removed from the house frame-leaving the house site open and exposed (Corney 1896:59). Regardless, periodic structure maintenance would have led to the re-excavation and re-filling of posts and wall trenches (Smith 2004:42-43, 48, 51). Much of the glass present was probably in secondary deposits, which would have been moved from their location of primary deposition. As such, they may have undergone damage from trampling or other activities which must be considered when 
interpreting whether the glass was intentionally modified. At Cathlapotle, faunaturbation and floraturbation were likely minor, but potential site impacts. Thus in some cases, artifacts were not recovered where they were deposited and were stratigraphically out of context (Smith 2004:58-63).

One factor that may also have influenced what glass was recovered was excavation methodology. Specifically, different screen sizes used to screen the matrix may have affected the size of vessel glass recovered. All sediment was screened through at least $1 / 4$ in. mesh $(6 \mathrm{~mm})$. Starting in 1994, in each 2 by $2 \mathrm{~m}$ excavation unit, 3 of the 4 quadrants were screened through just $1 / 4$ in. mesh. The remaining quadrant was screened through 1/8 in. $(3 \mathrm{~mm})$ mesh. Additional samples were water screened through 1/16 in. (2 mm) mesh (Ames et al. 1999: 27, 29, 31, 33). Consequently, very small fragments of glass may have not been recovered in matrix screened only through $1 / 4 \mathrm{in}$. mesh.

\section{Meier}

The Meier plankhouse (35CO05) is located near Scappoose, Oregon and the Multnomah Channel. The plankhouse dates to approximately A.D. 1400 and was occupied until 1810-1820 (Ames et al. 2011:15; Fuld 2012:26). It housed about 200 people. Like Cathlapotle, Meier was a permanent settlement (Ames et al. 2008:6; Fuld 2012:26).

There are no ethnohistoric accounts about Meier (Ames et al. 2011:14). It is not clear to what extent Meier participated in the fur trade, though the presence of trade 
goods suggests at least some involvement (Banach 2002; Kaehler 2002; Cromwell 2010; Ames et al. 2011).

Sometime after the Meier plankhouse was abandoned local land owner tradition notes the presence of a house frame on the site from the mid to late $19^{\text {th }}$ century (Smith 2004:56). There was also a late $19^{\text {th }}$ and early $20^{\text {th }}$ century farmer component at the site, where plowing took place (Cromwell 2010:v31). From this context, late $19^{\text {th }}$ and $20^{\text {th }}$ century artifacts were deposited including for example vessel glass, ceramics, nails, and barbed wire.

The Meier site was excavated by Pettigrew (1981), Ellis (n.d.), and most recently by Portland State University (PSU) from 1987 to 1991 (Ames et al. 1992; Smith 2004). The one large plankhouse measured 14 x 30 m (Fuld 2012:26). One large refuse midden was located to the east of the plankhouse along an adjacent creek (Ames et al. 1992:283) (Figure 6). The interior of the plankhouse was similar in layout to those at Cathlapotle, with central hearths and raised wooden benches along the walls. Unlike Cathlapotle, no storage pits were dug underneath the benches, but were instead placed in-between the bench and hearth. Some type of wooden floor would have been necessary to cover these pits and keep the inhabitants from falling into them. The open space beneath benches probably was used to stack wooden boxes for storage (Smith 2004:33-34). 


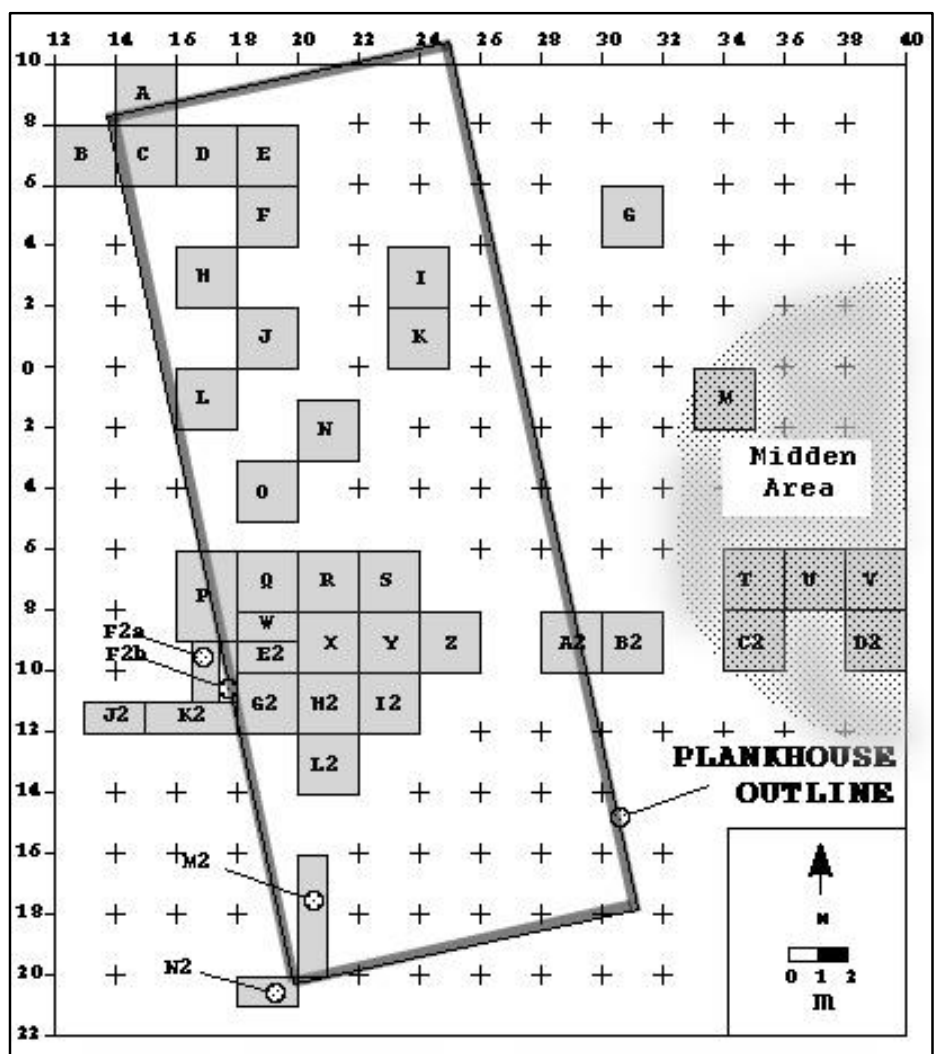

FIGURE 6. Site Map of Meier with Excavation Units (Courtesy Of Kenneth Ames)
Similar to Cathlapotle, the archaeology of Meier has been extensively written on (See Ames et al. 2011 for a summary). Research on the Meier artifact assemblages included: social organization (Smith 2004) and sedentism (Hamilton 1994) explored through tool technology; social hierarchy through the spatial analysis of ground stone (Wolf 1994); obsidian trade networks

(Sobel 2012); the projectile point assemblage (Davis 2010); the bone and antler tool assemblage (Davis 1998; Fuld 2012); the faunal assemblage (Lyman 1994); hearth features (Gardner-O’Kearny 2010); the ceramic assemblage (Cromwell 2010); copper (Banach 2002); and trade beads (Kaehler 2002).

The formation processes discussed above for Cathlapotle, including those associated with daily household and structure maintenance were also present at Meier. Unlike Cathlapotle, Meier had some type of wooden floor, therefore artifacts could have also become lost after falling between planks (Smith 2004: 36-37; 42-53, 58-63). Also, dropped glass may have broken easier on these planks than the earthen floors of 
Cathlapotle. Other post depositional processes include major episodes of pot hunting at Meier, as well as plowing associated with the land's historic and modern use as an agricultural field. Pot hunting may have removed or damaged artifacts and deposit stratigraphy, while plowing damaged artifacts moved them both horizontally and vertically (Smith 2004:56-57). The effects of plowing on glass artifacts and issues with identification of flaked glass are discussed in the methods chapter below.

During excavations at Meier, the majority of matrix was screened through $1 / 4$ in. mesh. Samples were screened through 1/8 in. mesh as well as wet screening with smaller mesh (Kaehler 2002:20; Ames, Personal Communication, 2014). Like Cathlapotle, this may have resulted in a recovery bias in terms of the size of glass found.

\section{Middle Village}

Middle Village, a component of the Station Camp/McGowan Site (45PC106), is located on the north side of the Columbia, approximately 11 miles upstream from the mouth of the Columbia River. The site is between Point Ellice and Chinook Point. The remains of at least three small plankhouses were located, though there may have been up to five plank houses altogether at the site. Middle Village dates from ca. AD 1788 to 1830 (Wilson et al. 2009).

The site of Middle Village has been identified as the historic Chinook village of qiì'ayaqilxam (translates as Middle Village). Ethnographic and ethnohistoric accounts along with archaeological data indicate that Middle Village was a seasonal summer trading village. It was located advantageously for trade upstream from the fur trade ships 
at Bakers Bay and across the river from fur trade post Fort Astoria/ George. Additionally, the majority of artifacts recovered were goods associated with the fur trade (Wilson et al. 2009:418-419).

Middle Village was visited in 1805 by the Lewis and Clark Expedition. The expedition camped there from November $15^{\text {th }}$ to $25^{\text {th }}$ in order to collect bearings on geographic features. This "Station Camp" was adjacent to a Chinook Village thought to be abandoned by the explorers on account of fleas (Moulton 1990[6]:36). It is however more likely that the village was empty simply because its residents had moved to their winter village (Wilson et al. 2009:21). While there, Lewis and Clark met with the two Chinook chiefs Concomly and Chilarlawil. The chiefs were given medals and a flag, and a small amount of trading was carried out (Moulton 1990[6]:72-73).

Middle Village was abandoned sometime around 1830. The abandonment may be associated with the relinquishment of Fort George (Fort Astoria) by the HBC in 1825 (Wilson et al 2009:390-391,420). Also possible, between 1830 and 1834, a series of malaria epidemics killed many Chinookans (Boyd 1999:84,242-245).

Middle Village was excavated by Columbia Diachronic Services, Inc., and the National Park Service (NPS) in coordination with PSU between 2002 and 2005 to mitigate the proposed realignment of U.S. Route 101 (Harrison 2002, 2003, 2004, 2005; Wilson et al. 2009). During fieldwork, portions of three plankhouse measuring $8 \times 10 \mathrm{~m}$ to $8 \times 12 \mathrm{~m}$ were excavated (Figure 7). Middens between houses and activity areas in front of houses were also identified. Similar to Cathlapotle and Meier, the interior of 
these plankhouses had a central hearth and raised wooden platforms/benches along the walls. At Middle Village storage pits were dug beneath the benches and there is no evidence of a wooden floor (Wilson et al. 2009: ii, 396-400).

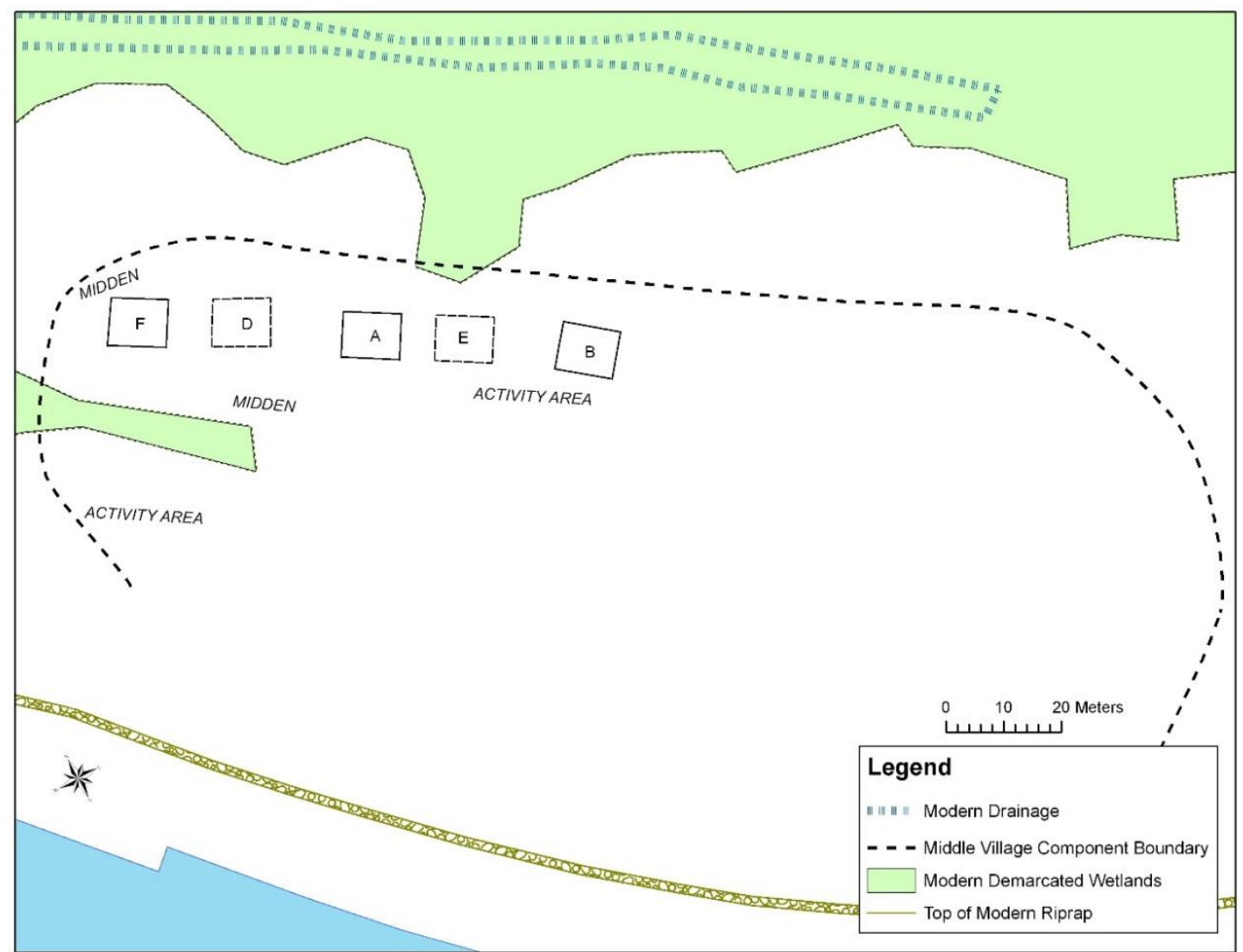

FIGURE 7. Site Map of Middle Village at Station Camp. Plankhouses D and E are Hypothetical (Courtesy Of Fort Vancouver National Historic Site)

The Area F plankhouse, which was the most extensively excavated, had a shed type roof, where planks ran perpendicular to the long side of the house (Wilson et al. 2009:397). This type of roof is different from the gable type common in the ethnographic literature (Ray 1938:124; Wilson et al. 2009:409). However, Ray (1938:126) suggests that summer houses used shed type roofs. The Area F plankhouse appears to have been 
occupied and reconstructed extensively, while the houses to the east show less evidence of occupation and reconstruction (Wilson et al. 2009:155,178, 410). As previously mentioned, ethnographic and historic accounts suggest that Chinookans dismantled their seasonal houses and stored the planks in ponds (Corney 1896:59; Ames et al. 1992:276), which may explain the frequent reconstruction of the structure (Wilson et al. 2009).

The site formation processes at Middle Village were similar to those at Meier and Cathlapotle. Within the plankhouses, debris from hearths and activity areas was moved into storage pits or the outside middens. Smaller artifacts were likely lost in artifact traps created by the sandy matrix which made up the floor. As mentioned above, there is also evidence that these seasonal plankhouses were dismantled or rebuilt periodically. Rebuilding, along with building maintenance activities, would have led to the reexcavation of wall plank trenches and posts. In the Area F plankhouse, a wall trench was constructed through an old hearth. Consequently, the hearth matrix would have been mixed with plank wall fill. There is also evidence that the Area F plankhouse burned in a slow, oxygen deficient fire which charred and preserved the planks. Lastly, the subsequent McGowan cannery, fishing village, and farm (ca. A.D. 1853-1930) disturbed some of the village components (Wilson et al. 2009:398-400).

At Middle Village, matrix was screened through nested $1 / 4$ in. and 1/8 in. screens. Additionally, in some contexts 5 litter buckets were taken for water screening through 1/16 in. mesh (Wilson et al. 2009: 57, 208, 233). This sampling strategy was done to control for recovery bias. 


\section{HBC Employee Village}

The last site explored in this study is the Employee Village (also known as Kanaka Village) at the HBC's Fort Vancouver. As previously mentioned, the Employee Village was a multiethnic community that housed workers from diverse backgrounds from ca. AD 1825 to 1860. These included: British, French Canadians, Orkney Islanders, Scots, a few Americans, Hawaiians, and various Native American groups including Chinookans, and Métis (Mullaley 2011:1; Wynia 2013:10).

Numerous archaeological excavations have been conducted in the Employee Village (Kardas and Larabee 1970; Chance and Chance 1976; Chance et al. 1982;

Thomas and Hibbs 1984; Thomas 1987, 1993; Gembala et al. 2004; Wilson 2005), which have identified the location of several villagers' houses and numerous features. Studies have been conducted on economic variation and consumer choice through the study of the ceramics (Cromwell 2006, Holschuh 2013), Village architecture (Mullaley 2011), refuse patterns through tobacco pipe distribution (Wynia 2013), and gender through the analysis of beads (Stone 2010). A number of studies (Kardas 1971; Bray 1984) attempted to identify the ethnicity of Village households through the types of artifacts recovered. These studies were unsuccessful in identifying artifacts or artifact patterns which could be associated with one ethnic group.

The two houses used in this study, designated Operation 56 and 57, were excavated by Thomas and Hibbs (1984) in 1980 and 1981 as part of the mitigation for improvements on Interstate 5, at the intersection of State Highway 14. These houses date from ca.1846 to 1855 . Through the use of the Covington 1846 map, Thomas and Hibbs 
were able to associate Operation 56 and 57 with the households of French Canadian fur traders Charlebois and Little Proulx respectively (Figure 8).

Thomas and Hibbs (1984:578) identified Charlebois (Operation 56) as Paul Charlebois. In the 1850 Clark County Census, he was listed as age 27, Canadian born, and employed as a laborer. His residence was listed as House Number 35 and he was living with three other men (McLellan 1935: Appendix E, xvii). Catholic Church records identified Paul Charlesbois' wife as Marie, a Chehalis Indian (Warner and Munnick 1972: 108[M-1]). They had three children: Charles, born in 1850, Victorie, in 1852, and Sara in 1855 (Warner and Munnick 1972:112[B-14], 125[B-4], 151[B-1]). In addition, Catholic Church records indicate that one Paul of the Walla Walla Tribe was living in the household in 1853 at which time he was baptized (Warner and Munnick 1972: 134[B-3]. The last mention of the Charlebois' is in 1855 at the time of their daughter Sara's baptism.

The house of Little Proulx, Operation 57, is located to the south of Charlebois' residence. Thomas and Hibbs (1984:578), suggest that this was the house of Francois Proulx (Figure 8). Catholic Church records indicate that on 31 January 1847 Francois Proulx at the age of 31 married Catherine, a Chinookan Indian (Warner and Munnick 1972: 78[M-42]). The only other historical records for Francois Proulx were the baptism and death of his daughter Louise on 25 April 1852 and 1 October 1852 respectively (Warner and Munnick 1972:129[B-12], 130[S-5]). Thomas and Hibbs (1984:579) postulated that Proulx worked as a voyageur, and therefore he was not present in the 1850 Clark County Census. No other historical records exist for Proulx. 

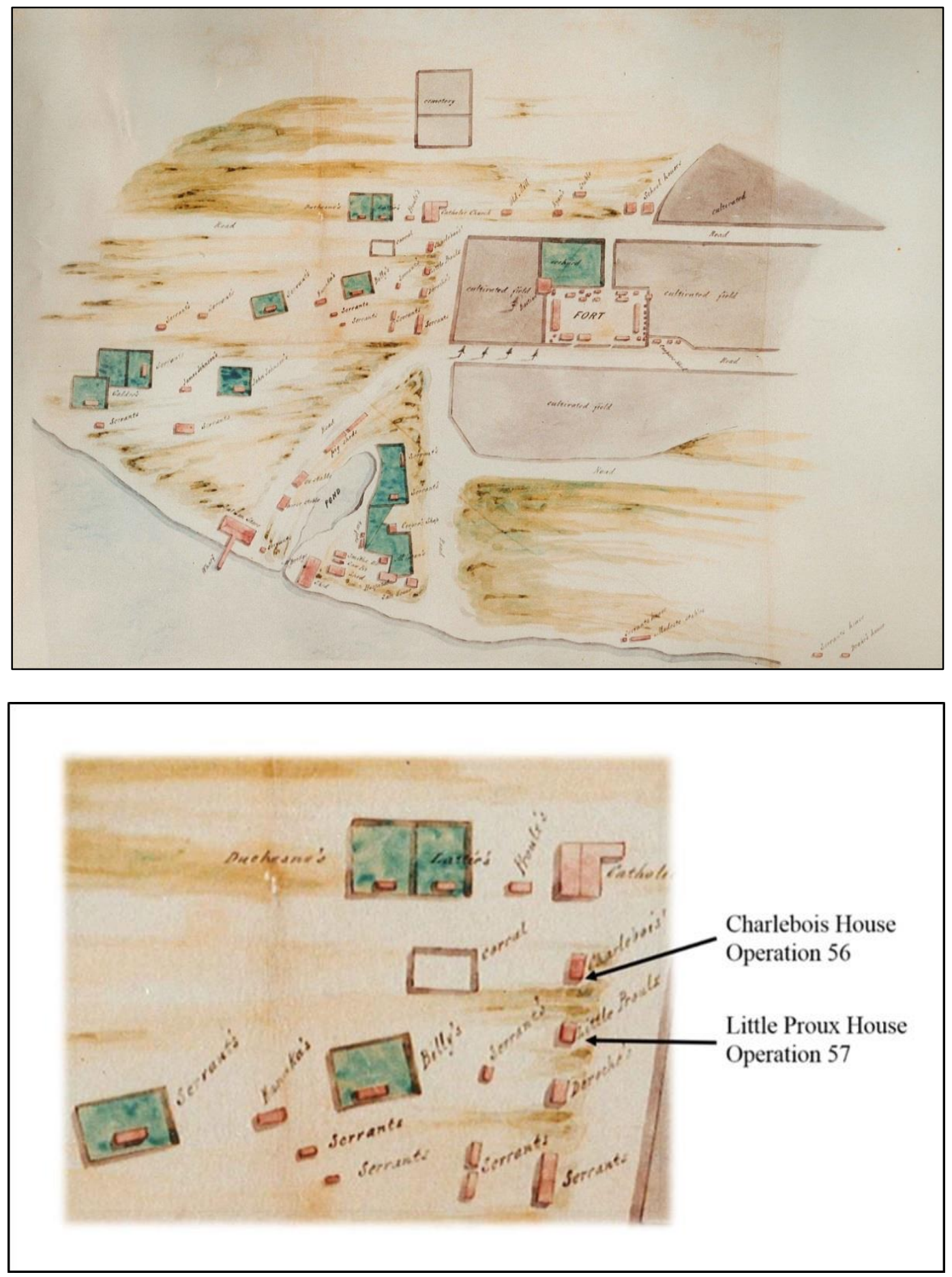

FIGURE 8. Above: 1846 Covington Map of Fort Vancouver. Below: Detail of the Locations of Houses used in Study. (Courtesy of Fort Vancouver National Historic Site) 
In Operation 56, 18 features were recovered within Stratum III which was associated with the Village occupation (Thomas and Hibbs 1984:591-592, 596). This included five posts, one stake, four pits, two fire areas, four lineal features, and one surficial feature. Additionally one rodent hole feature was intrusive through this stratum. The posts were square/rectangular shaped and placed within circular holes. Thomas and Hibbs were not able to associate these positively with the house structure. However, one of the pits, Feature 17, had wood fragments and nails at its base and was thought to be part of a foundation trench. A surficial feature, Feature 16, was made up of a lens of wood fiber and was interpreted as flooring. The fire areas had stratified lenses of charcoal, ash, a mixture of charcoal, ash, and burned bone, which was beneath dark brown loam soil. The lineal features running northeast to southeast were interpreted as wagon ruts associated with the precursor of the McLoughlin Road (Thomas and Hibbs 1984:583,591-592,596). Overall no house and yard boundaries could be reconstructed based on Thomas and Hibbs' excavation.

In Operation 57, five features were associated with Stratum III. These included four post holes and one pit feature. The post holes were defined by soil casts created by poor preservation of the wood. One circular post in a squared hole was found. This type of post was associated with house foundation posts. The pit feature was not easily accessible and not excavated (Thomas and Hibbs 1984:596-598).

A number of site formation processes were present at the HBC Employee Village. Site impacts include the Columbia River flooding, U.S. Army destruction of the Village, U.S. Army Quartermaster installation, the building of Civilian Conservation Corps 
offices and barracks, railroad berm construction and the addition of fill to create the berm, road construction, and archaeological investigations over the last fifty years (Erigero 1992).

Matrix from Thomas and Hibb's excavations was only screened through $1 / 4$ in. mesh (Thomas and Hibbs 1984: 21). As a result smaller pieces of glass may have not been recovered.

TABLE 2. Comparison of Four Sites

\begin{tabular}{|c|c|c|c|c|}
\hline & Cathlapotle & Meier & $\begin{array}{l}\text { Middle } \\
\text { Village }\end{array}$ & $\begin{array}{c}\text { Fort Vancouver } \\
\text { (Op 56\&57) }\end{array}$ \\
\hline $\begin{array}{l}\text { Smithsonian } \\
\text { No. }\end{array}$ & 45CL1 & $35 \mathrm{CO} 5$ & $45 \mathrm{PC} 106$ & $45 \mathrm{CL}$ \\
\hline $\begin{array}{l}\text { Coast vs. } \\
\text { Inland }\end{array}$ & Inland & Inland & Coast & Inland \\
\hline Occupation & $\begin{array}{c}\text { ca. A.D. } \\
\text { 1450- } 1832\end{array}$ & $\begin{array}{l}\text { ca. A.D. } 1400- \\
1810-1820\end{array}$ & $\begin{array}{l}\text { ca. A.D. } \\
1788-1830\end{array}$ & A.D. $1846-1855$ \\
\hline $\begin{array}{l}\text { No. of } \\
\text { Houses }\end{array}$ & 6 & 1 & 5 & 2 \\
\hline $\begin{array}{l}\text { Area } \\
\text { Excavated }\end{array}$ & $309 \mathrm{~m}^{2}$ & $155 \mathrm{~m}^{2}$ & $143 \mathrm{~m}^{2}$ & $98 \mathrm{~m}^{2}$ \\
\hline $\begin{array}{l}\text { Total } \\
\text { Vessel } \\
\text { Glass }\end{array}$ & 77 & $24 *$ & 536 & 459 \\
\hline
\end{tabular}

* A total of 264 glass shards were recovered at Meier; only 24 were not in the plow zone contexts and were clearly associated with the Chinookan occupation. 


\section{Chapter 4: Theoretical Background}

This chapter provides the theoretical framework for this study, including a discussion of cultural contact and colonialism, as well as practice theory as a paradigm to study everyday household activities. Previous studies of flaked glass tools are then reviewed and this studies' research hypotheses are laid out.

\section{Cultural Contact and Colonialism}

In the past, few archaeologists studied Native American groups post contact. Instead this period was relegated to the ethnohistorian who in the past were often influenced by the written accounts of colonizers rather than Native Peoples' oral traditions and histories (Rubertone 2000:426). Today, researchers are increasingly studying the period of "contact" of Europeans and others, with Native Americans. Through the study of the post contact Native Americans' archaeological record, research has focused on such issues as how identity was constructed (Burley 1989; Lightfoot et al. 1998; Martindale 2009; Silliman 2001; Voss 2008), how new economic and power relations developed (Lightfoot 2005; Silliman 2001), the effects of disease on native populations (Erlandson and Bartoy 1995), and how new materials and objects were or were not incorporated into traditional culture (Martindale and Jurakic 2006; Silliman 2001). These topics provide a greater insight into not only what happened to Native American tribes, but also to American colonists in the past (Lightfoot 2005). 
Although the term "culture contact" is often used to discuss interactions between different cultures, some researchers have criticized this terminology. Silliman (2005:56) has three objections to its use, specifically that culture contact:

(1) emphasizes short-term encounters over long term entanglements; (2) downplays the severity of interaction between groups and the radically different levels of political power that structured those relationships; and (3) privileges predefined and almost essentialized cultural traits over creative, creolized, or novel cultural products.

Consequently, the term contact gives the false impression of brief encounters between isolated and static cultures, which have equal levels of power. Such scenarios are unrepresentative of the fact that cultures are always interacting with other cultures, and that culture is continuously changing. Nor would many Native Peoples define the entanglements that occurred with Europeans and Americans as merely contact where no group had power over another (Silliman 2005).

Silliman (2005:59) suggests that colonialism is a more appropriate term to discuss such entanglements between cultures. He defines colonialism as the dual process:

(1) of attempted domination by a colonial/settler population based on perceptions and actions of inequality, racism, oppression, labor control, economic marginalization, and dispossession and (2) of resistance, acquiescence and living through these by indigenous people who never permit these processes to become final and complete and who frequently retain or remake identities and traditions in the face of often brutal conditions.

However, this is not to say that there were no instances where cultures met and none held power over the other. Colonial encounters also should not be emphasized, "as the single transforming, if not traumatic, event in Native Peoples' lives, rather than acknowledging their ability to withstand and sometimes resist these invasions and the incursions that 
followed" (Rubertone 2000:434-35). In this work I will use the term colonialism within the above context.

In the past, culture contact was often envisioned as a process where "an exchange, adoption, retention, and discard of cultural traits" took place (Silliman 2005:65). This view is rooted in the model of acculturation, where one culture adopts the material goods of another. Not only are material goods adopted, but the meaning behind these goods becomes part of that culture (Upton 1996:1-2). As a result, previous archaeological studies of the contact period focused on the amount of "traditional" artifacts versus those of European or other origin in order to gauge how much Native Americans had assimilated into European or American culture (Rubertone 2000:428). Acculturation has generally been rejected as a mechanism to explain culture change. This concept has many failings, including the notion that the exchange of goods and ideas was asymmetrical, that to accept an object one accepts any meaning behind that object, and finally that such complex issues as identity and ethnicity could be boiled down to simple artifact ratios (Lightfoot 1995:206). Researchers now recognize that the adoption of new materials or technology is multifaceted, "involving various economic, political, ideological, and engendered considerations, and that Native Peoples were active participants in selecting or modifying new artifact forms" (Lightfoot 1995:206). Additionally, even before faceto-face contact occurred with Europeans and other groups, many native populations were impacted by the introduction of new European goods, and alien plants and animals, as well as, the assault of epidemics. Furthermore, studying this post-contact period as simply encounters between two distinct groups "European" and "Indian," is 
unrepresentative of the complexity of the real world. Relationships took place between many native populations, people of European descent from numerous nationalities and backgrounds, as well as other non-European groups (Lightfoot 1995:206).

With recognition of these complexities, researchers have turned to various methods of studying colonial encounters between native populations and outside groups. Power relationships are one increasingly important avenue of study (Mullins 2008); and the study of material culture has been successful in identifying how power relationships were negotiated by Native Peoples (Wilson and Rogers 1993; Silliman 2001, 2005; Lightfoot 2005; Voss 2008; Rodríguez-Alegría 2010). For example, Rodríguez-Alegría (2010) looks at how two different classes of Native Peoples used Spanish material culture to negotiate power relations in 16th and 17th Century Northern Mexico. Upper elites used Spanish dress and weaponry, symbols of the powerful conqueror, to mark and reinforce their power. Lower elites used Spanish ceramics at feasts as displays of status and wealth, creating a mechanism to move up the social hierarchy.

Creolization, a concept used in linguistics and cultural anthropology has been adapted by archaeologists to study contact and culture change (Ferguson 2000). However, there is no agreed upon definition of this concept. Archaeologists have used this term to described the mixing of cultures or ethnicities, the creation of a completely new culture which may or may not result from intermarriage and children, the incorporation of foreign material or object into a culture, or a combination of these phenomena (Dawdy 2000:1). I do not reject any of these interpretations of creolization, but in this work I use the term most similarly to Lightfoot and Martinez (1995). They 
write that the process of creolization is "how people modify, create, and syncretize material objects in culture contact situations" (Lightfoot and Martinez 1995:482). In this paradigm, a European object for example might be used by another culture in a "nonEuropean" way (Ferguson 2000:7). In this study then, bottles used by Chinookans to create tools would be considered an example of creolization.

Studies have also focused on entanglement which builds on the ideas of hybridity and creolization (Thomas 1991; Orser 1996; Dietler 1998; Silliman 2001; Stahl 2002; Harrison 2004; Martindale 2009). This concept is rooted in the work of Thomas (1991) who interprets the encounter between native populations and others as having an aspect of symmetry—where individuals negotiate new and old economic opportunities, as well as, social relationships through which they recontextualize material culture. In this paradigm contact becomes "a historical process of entanglement in which cultural worlds were constructed through use of various objects or behaviors, as much as through conscious choice" (Martindale 2009:64). Using the example of the Tsimshian on the Northern coast of British-Columbia, Canada, Martindale (2009) shows cultural transitions are complex, multifaceted processes. The Tsimshian do not increasingly use more items of European origin over time, rather both Native and European items are used and not used at different time periods, for a variety of reasons. Additionally, the meaning behind such items does not remain the same, nor do the Tsimshian accept the European meaning of objects, but often create their own.

Related to this concept of entanglement is that of ethnogenesis. Voss (2008:1) defines ethnogenesis as the creation of new cultural identities. Ethnicity or cultural 
identity can be viewed as a cultural dialogue. This dialogue is not fixed or stable overtime, but rather an ongoing social process. The concept of overdetermination is used by Voss in her explanation of ethnogenesis. This concept's premise is that social phenomena are created by "an infinite number of contributing and interacting phenomena" (Voss 2008:5). In the case of ethnogenesis then, the creation of new cultures and cultural entities cannot be boiled down to one cause, but is the result of a vast number of factors. Even though there are numerous causes which lead to ethnogenesis, the context of colonialism is particularly persuasive for generating conditions where existing forms of identity are replaced with new ones (Voss 2008:1,3$5)$.

\section{Daily Practices and Practice Theory}

Issues of agency are at the center of scholarship concerning colonialism and culture change (Silliman 2001:192). Simply put, how should the individuals who lived within such contexts be understood? Are they rational actors, whose every action is a deliberate attempt to improve their situations (Blanton et al. 1996; Joyce and Winter 1996)? Conversely, are these individuals' "acting meaningfully in historical and social circumstances only partly of their own making" (Silliman 2001:192; see also Johnson 1989; Dobres and Hoffman 1994; Barrett 2000; Pauketat 2000; Wilkie and Bartoy 2000).

Although agency is often debated by social theorists, this issue has important implications for archaeologists. Since we study the material culture left behind by people, how we view agency affects how material culture and the behaviors it represents are 
interpreted. Increasingly, many historical archaeologists have turned to practice theory in order to explain agency (Lightfoot et al 1998; Silliman 2001).

Developed by Bourdieu (1977) and further elaborated by Giddens (1979) and Sahlins (1981), practice theory "seeks to explain the relationship(s) that obtain between human action," or practice "on the one hand, and some global entity which we may call 'the system' on the other" (Ortner 1984: 392). Practice can be conceptualized as "anything people do" (Ortner 1984:193), with a strong emphasis on those that have political/power ramifications; while the system or structure is the cultural or societal whole which people inhabit (Ortner 1984:390, 392, 1996:12-13, 20). The actor is both constrained and enabled by the system in which they live, yet also is able to reproduce and even change the system. This is not to say that individuals always intentionally change the system, rather change is usually the byproduct of unintended consequences (Ortner 1984:390,393,401, 2006:129-130,134-135,152).

Some archaeologists using practice theory have adapted the theory to focus primarily on day-to-day living. People's daily practices, such as how space is structured, garbage is disposed, and routine tasks are conducted are the focus of study. These details of everyday life provide clues to how culture is structured, and how individuals make sense of this structure (Lightfoot et al. 1998:199-200,202). Within situations of colonialism and culture contact, daily practices may be adopted, modified, or maintained; and understood "in ways that both make sense of 'others' and best suit their own interests" (Lightfoot et al. 1998:202). For example, Lightfoot et al. (1998) finds that Native Californian women and Native Alaskan men, who married at Fort Ross, continued 
to reinforce their identities through daily practices. Native women disposed of refuse in a manner similar to what they had done in their home villages; while Alaskan men's influence is seen in the amount of seafood that was consumed in their diets. Although both genders had new identities not only as part of an interethnic household, but also within the society of Fort Ross, they often continued to maintain their identities as Native Californian women or Native Alaskan men.

Silliman (2001) also uses a vein of practice theory similar to Lightfoot et al.'s (1998), but puts greater focus on power relations. In Silliman's (2001) study of Native American workers on a California rancho during the nineteenth century, he looks at why workers continued to use stone tools when they had access to European American tools that in some cases may have worked better than stone ones. He concludes that they chose to make and use such tools as a form of resistance, not in actively resisting outside power, but rather reinforcing their identity versus that of the non-native.

\section{The Study of Modified Glass}

In contexts of colonialism and culture contact, tools manufactured from broken glass are often found at archaeological sites. As previously discussed, glass tools are not specific to any one culture, but have been created worldwide (Conte and Romero 2008:249-250). In some archaeological literature the presence of flaked glass is noted, but no explanation is provided for its presence (Runnels 1975, 1976). While other researchers have become interested in why glass was modified and have proposed a variety of explanations to why different cultures created glass tools. These explanations include: glass’ physical properties (Clark 1981; Kehrberg 1992; Robbin et al. 2004; 
Conte and Romero 2008); creolization (Martindale and Jurakic 2006); resistance (Silliman 2001; Harrison 2003; Martindale and Jurakic 2006); material availability (Wilkie 1996; Martindale and Jurakic 2006); or a combination of these factors (Martindale and Jurakic 2006).

Conte and Romero (2008:249) suggest that the ability to easily fracture glass into a variety of sharp tools is one of the reasons that glass has been frequently modified. Glass has physical properties similar to obsidian, a material valued for constructing tools by many groups. Consequently, glass may have been used as a substitute for other raw materials. For example, African Americans on a Louisiana plantation constructed razors out of glass when purchasing razors would be too expensive otherwise. When cheaper razors became available, there was a decline and then disappearance in the use of these glass tools (Wilkie 1996). Glass tools have been previously noted in the Cathlapotle assemblage by Sobel (2004:643-645), who also explains their presence in materialistic terms. In this case, glass was just another raw material that was not highly sought after based on the small number of specimens.

Another explanation is that of creolization. In their study of modified glass created by the Northern Tsimshian, Martindale and Jurakic (2006) propose that such tools are an example of creolization. In this case, a hybridity of Northern Tsimshian and European culture where nontraditional (European) materials were incorporated within the Tsimshian framework of economic prudence and resourcefulness by recycling a common good, glass. This is just one aspect of a multifaceted response to colonization that includes resistance and economic resourcefulness (Martindale and Jurakic 2006). 
Resistance to colonizers is suggested by a number of scholars as a factor for the use of flaked glass tools. As mentioned above, Martindale and Jurakic (2006:425) suggest that these tools "may reflect Tsimshian ... desire to distinguish themselves from European values by recycling broken objects in a manner that was both unfamiliar to Europeans and somewhat contrary to the consumer economic of the market economy". The Tsimshian are resisting the European market economy culture by not purchasing foreign goods, but also by reusing a material that Europeans regard as useless and trash (Martindale and Jurakic 2006). In an Australian example, Harrison (2003) interprets the creation of glass tools by Australian Aborigines as symbolic resistance to their colonizers. Through creating traditional technological items using the materials of another culture, the Aborigines "literally [transform] 'European' into 'Aboriginal' objects" (Harrison 2003:327). Within the context of the colonizer's overarching hegemony, the Aborigines are able to push back symbolically when they cannot physically.

\section{Research Hypotheses}

In this study, the paradigm of practice theory is used to explore the impact of contact/colonization on the Chinookan people and the later HBC multiethnic community at Fort Vancouver. Specifically, I look at how the new material of vessel glass was and was not incorporated into the everyday activities of tool production and tool use. Four hypotheses and their associated test expectations were developed. 


\section{Hypothesis \#1}

$H_{O}$. With the introduction of vessel glass it is expected that the Chinookan peoples used glass to create tools.

$H_{A}$. The introduction of vessel glass did not result in Chinookan people creating glass tools.

With the introduction of trade goods, vessel glass with its ability to be flaked or modified into a variety of tools is expected to become a new raw material for the creation of tools. The presence of glass tools in archaeological assemblages shows that Chinookan peoples were choosing to use a new material for the creation of tools. This incorporation of a foreign object into Chinookan culture is an indicator of the broader process of ethnogenesis and creolization taking place. By incorporating a foreign material into their toolkit, Chinookans are changing what materials can be used to create tools in their culture - thus changing the larger system. Their culture is also being changed with the new acquisition of vessel glass, whether intentionally for use solely as a raw material or unintentionally as a byproduct of obtaining the substances within bottles.

The null hypothesis is that vessel glass was not used to create tools. This may have been because of a lack of vessel glass to use as a raw material. However, if unmodified vessel glass is present it seems likely that a type of resistance is taking place. Resistance in this sense probably arises out of a daily choice to reject glass as a raw material appropriate for creating tools within their system. 


\section{Hypothesis \#2}

$H_{O}$. Changing lifeways as a result of contact and participation in the fur trade economy will result in a glass tool technology that differs from traditional stone tool technology.

$H_{A}$. Changing lifeways and participation in the fur trade economy will not affect glass tool technology; so that glass tool technology will not differ from traditional stone tool technology.

As discussed in Chapter 2, contact and colonization produced many changes for Chinookan peoples. To name just a few of the effects: new goods were introduced; Chinookan peoples became involved in the global fur trade; and epidemic diseases killed large portions of the population. Consequently it is expected that these changes in life ways will be reflected in the everyday practice of how tools were created. Glass tools then will not completely mimic traditional stone tool technology (discussed further below).

In addition, one way that glass tools may reflect changes related to the fur trade economy is the production of glass hide scrapers. Chinookan peoples both produced and supplied clamons (elk hide armor), which were an important part of the exchange system both prehistorically and during the contact period (Gibson 1992:10-11; Boyd 2011:1415). Archaeologically at Cathlapotle there appears to have been an increase in hide production, perhaps for clamons, as measured by hide scrapers after contact (Smith 2006:139; Ames et al. 2011:39). The presence of glass hide scrapers then may be another reflection of this change. Lithic hide scrapers are characterized by excurvate edges that have broad/wide edge angles in order to prevent them from slicing into the hide (Smith 2004:87); and glass scrapers associated with pelt or hide production therefore should 
meet these attributes. Of course it is unlikely that all Chinookan groups participated in the fur trade in the same ways or to the same extent, and this subject will be further explored in Hypothesis 3.

Conversely, contact and the fur trade economy may have had little impact on the practice of tool making and the types of tools produced with regard to glass tools. As a result these glass tools would not differ from traditional lithic technology previously discussed in Chapter 2. These glass tools then would be expected to be dominated by expedient/low energy tools used for a variety of functions as measured by relative frequency of tool type/function. Yet, given glass' similar physical properties to obsidian it is also expected that a portion of these tools will be projectile points.

Furthermore, glass tools may not reflect clamon or hide production as indicated by glass hide scrapers. At both Cathlapotle and Meier, only a few obsidian hide scrapers were present archaeologically (Sobel 2004; Ames, Personnel Communication 2014). Given glass' similar physical properties to obsidian it may not have been considered an inappropriate material by Chinookans for this type of tool. Glass as a raw material for hide scrapers cannot be ruled out completely, since other groups, e.g., the Konso of Ethiopia, are documented to have produced glass hide scrapers (Kimura 2006).

\section{$\underline{\text { Hypothesis \#3 }}$}

Ho. Varied responses to contact and participation in the fur trade economy will result in differences in the amount of vessel glass, modified glass, and glass tool forms/functions between Chinookan sites. 
$H_{A}$. Varied responses and participation in the fur trade economy will not result in differences in the amounts of vessel and modified glass, as well as tool forms and functions at the three Chinookan sites.

Ultimately how Chinookans responded to contact and colonization is not expected to be uniform across the region, but rather be multifaceted and context specific. Factors such as village location and the degree and type of involvement in the fur trade are expected to affect the amount of vessel glass, modified glass, and types of tool forms and functions.

The Chinook at the mouth of the Columbia River, including those at Middle Village, were powerful players in the fur trade economy. Their location at the intersection of major trade routes between the interior and coast, the wealth of natural resources, and their past role as middle men in native trade routes allowed them to control much of the fur trade and trade goods between Europeans and the surrounding indigenous populations (Wilson et al. 2009).

Further upriver, Chinookan peoples at Cathlapotle may not have participated as directly in the fur trade. For much of the early fur trade, Cathlapotle was located away from the anchorages of trading vessels at the mouth of the Columbia, as well as Fort Astoria, which was the main terrestrial fur trade fort during this time. Even so, historical accounts indicate that fur traders stopped periodically at Cathlapotle, which was located on the major thoroughfare of the Columbia River (Boyd 2011); and Chinookans from Cathlapotle also visited Fort Astoria/George from time to time (Jones 1999). In addition, the presence of European trade goods indicates some type of involvement in the fur trade 
economy (though possibly indirectly through other native groups) (Ames et al. 1999;

Smith 2004; Sobel 2004). Then in 1824, Fort Vancouver was established to the south and east of Cathlapotle (Erigero 1992:13-14). For several years before the devastating disease epidemics of the 1830 s, Cathlapotle was in close proximity to a fur trade hub. Although it is unknown to what extent trade was carried out between Cathlapotle's residents and the fort.

Meier's degree of involvement in the fur trade is unknown. No historical accounts exist for Meier, and the village is located inland away from the Columbia River-making it the most isolated of the three sites (Ames et al. 2011:14). Though, there is evidence of increased production of worked bone post contact (Fuld 2011), perhaps as result of trade intensification with other native groups as a result of the new fur trade economy (Ames et al. 2011). Even so, trade goods are not present to the extent of Cathlapotle (Banach 2002; Kaehler 2002; Cromwell 2010).

As a result of these factors, it is expected that:

1) Middle Village will have the greatest areal density of glass per square meter for contact period deposits. This is because of its close proximity to both Fort Astoria and the anchorages for fur trade ships over a 30 plus year period. Consequently, I am assuming that Middle Village would have had more access to European goods, such as glass, over a longer period of time than Cathlapotle and Meier; and that these goods would trickle outward from Middle Village to surrounding areas 
as suggested by the study of exchange networks (Renfrew 1972; Hodder 1974; Webb 1974).

2) Meier will have the lowest areal density of glass per square meter because of its relative isolation from the main trade routes and later Fort Vancouver, and smallest amount of trade goods overall.

3) Cathlapotle should have less glass per square meter than Middle Village, but a greater amount than Meier because of its proximity to the Columbia River at an important riverside location, as well as Fort Vancouver after 1824.

How each village participated in the fur trade is also expected to vary between sites. Archaeological research indicates that Middle Village was primarily established during the first 30 years of the fur trade to serve as a seasonal trading village where goods were acquired and consumed. Few lithic tools were produced here based on the low frequency of debitage per finished tools (Smith 2009:261). Additionally, there is little archaeological evidence for the production of clamons or hides through the presence of hide scrapers (Smith 2009:273). It is plausible that the Chinook at Middle Village acquired hides and clamons from nearby local groups to trade with the fur traders.

In contrast, Meier and Cathlapotle were occupied for many centuries before contact, and were permanent villages occupied year round. At both sites, lithic debitage and tools occur in large numbers indicating the importance of stone tool production and use at these sites (Smith 2004; Wilson et al. 2009:273; Ames et al. 2011). 
Archaeological evidence and historical accounts suggest that Cathlapotle was a major producer of clamons (Smith 2004:175; Ames et al. 2011:39; Boyd 2011:14). There is no evidence for Meier producing clamons or hides in general at such a level (Ames et al. 2011:39). However, as discussed in the Hypothesis \#2, hide scrapers were only rarely produced with obsidian at Meier and Cathlapotle (Sobel 2004; Ames, Personnel Communication 2014). Consequently, glass, which has properties similar to obsidian, may not have been considered appropriate for hide scraper production and thus not used.

Based on these differences, the following trends are expected:

1) At Middle Village:

A) The areal density of modified glass shards (debitage and tools) per excavated square meter is expected to be less than the other two sites. Additionally, the percentage of modified glass out of total glass recovered from Middle Village is expected to be lower than the other two sites. This is the result of Middle Village being established primarily for the trade and consumption of goods, rather than the production of tools.

B) If hide scrapers are recovered at any of the three sites, Middle Village is expected to have the lowest areal density of hide scrapers (as described and defined previously in Hypothesis \# 2) measured per excavated square meter. This trend would result from clamons being acquired from other native groups.

2) At Cathlapotle: 
A) The areal density of modified glass shards (debitage and tools) excavated per square meter is expected to be similar to Meier, but greater than Middle Village. The percentage of modified glass within the assemblage is also expected to be similar to Meier, but greater than Middle Village. Both patterns are predicted based on the large amount of precontact lithic tool production at these sites.

B) If any glass hide scrapers are recovered, the highest areal density of hide scrapers per square meter to produce clamons and hides is expected at Cathlapotle. This is because of Cathlapotle's role as a supplier of clamons based on the archaeological and ethnohistoric record and their location along the major trade route of the Columbia.

3) At Meier:

A) The areal density of modified glass (debitage and tools) per excavated square meter is expected to be similar to Cathlapotle, as well as the percentage of modified glass given the importance of tool production and tool related activities at these sites compared to Middle Village.

B) If evidence of glass hide scrapers used to produce hides and clamons is found, it will occur at a lower areal density per square meter than Cathlapotle. This is the result of Meier's distance from the main trade routes and later Fort Vancouver, as well as the less importance of clamon production prehistorically at Meier. 
The null hypothesis is that all three sites will show similar patterns in amounts of glass, degree of tool production, and types of tools as measured above. This may indicate that the process of ethnogenesis is taking place at a larger regional scale, or other unknown factors are at work leading to similar patterns in how much glass is acquired and used to make tools, as well as what type of tools are created.

\section{Hypothesis \#4}

Ho. Over time from Chinookan villages to the new fur trade culture at the HBC Village which contained inhabitants from many different cultures, it is expected that the amount of vessel glass will increase; while the amount of modified glass tools will decrease; and glass projectile points will disappear completely from the archaeological assemblage.

$H_{A}$. Changes over time will not lead to an increase in the amount of vessel glass; modified glass tools will increase; and projectile points will still be present.

Contact and colonization saw some Chinookans taking on new roles as workers for fur trader companies like the HBC, while new political and economic alliances were also formed by Chinookan women marrying fur traders. These Chinookans who worked for the HBC or were married to their employees settled in the Employee Village at Fort Vancouver (Kardas 1971:167, 210; Erigero 1992:56, 64-65; Mackie 1997:33; Mullaley 2011:18; Lang 2013:266, 269). The polyglot of cultures within the Village, of which the Chinookans made up a large portion, created a new multiethnic fur trade culture (Kardas 1971; Mullaley 2011; Wynia 2013). This new culture is expected to differ from Chinookan culture as a result of changing lifeways. First, greater access to European trade goods, specifically the greater availability and proximity of goods contained in glass vessels will lead to an increase in the areal density of vessel glass shards per square 
meter. Secondly, the areal density of modified glass tools per square meter and percentage of glass that is modified will decrease with the greater availability and wide usage of metal tools. Lastly, glass projectile points are not expected to be present at the Employee Village with the wide availability of firearms at Fort Vancouver which could be used for hunting.

In contrast, a decrease in vessel glass shards and an increase in the amount of modified glass and glass projectile points may be indicative of resistance against the HBC. If the Villagers are resisting the HBC economic hierarchy which placed higher prices on goods for non-European than European (Cromwell 2006:125,127-128; Mullaley 2011:18; Holschuh 2013:81-82), they might not purchase commodities like medicine or alcohol that came in bottles. As a result the areal density of vessel glass shards per square meter would decrease. In addition, metal tools would have also cost more for Village residents than the company's elite. An increase in the areal density of modified glass tools per square meter and percentage of glass modified into tools may indicate that Village residents resisted the HBC's hegemony by choosing to recycle glass into tools instead of purchasing metal tools. Finally, an increase in the areal density per square meter and percentage of tools that are glass projectile points indicates that Village residents are choosing to use traditional bow and arrow technology rather than rifles. This choice to use bow and arrow technology may be a continuation of traditional practices or perhaps because the available rifles lacked accuracy. In either case, by using bow and arrow technology, the Village inhabitants are also rejecting the European rifle as the "proper/best" tool for hunting. 


\section{Chapter 5: Methods and Materials}

This chapter provides the methodology used in this study. The data sample is discussed, followed by vessel glass analysis procedures. Next the identification of flaked glass is explored, then methods for glass debitage and flaked glass tool analyses are outlined. Finally, the quantitative methodology is given.

\section{Data Sample}

For this thesis I analyzed all glass artifacts recovered from Cathlapotle and Meier, as well as a sample of glass artifacts from the HBC Village. The sample sizes from Cathlapotle and Meier are 80 and 272 artifacts respectively. The glass sample from the HBC Village was the glass artifacts recovered from Stratum III (the Village period occupation) of Operations 56 and 57. However, glass from disturbed features, such as a wagon road running through Operation 56, was not included. Operations 56 and 57 were selected because they were associated with fur traders who had native wives (Thomas and Hibbs 1984). Each of these houses likely had numerous inhabitants during their existence (Mullaley 2011:3-4), but at least during one part of their occupation each of these houses were associated with a local Native American occupant.

The Meier assemblage was further sampled to control for post depositional formation processes, specifically plowing. All glass was analyzed, but glass from the context identified as plow zone was considered to be from a mixed context. The effects of plows and other agricultural equipment on archaeological assemblages have been well documented (Mallouf 1982; Ammerman 1985; Odell and Cowan 1987; Dunnell and 
Simek 1995; Bloemker and Oakley 1999). These studies show that not only do plows move artifacts horizontally and vertically within the matrix, but also break and damage artifacts. Consequently, the glass from this context cannot be tied stratigraphically to the plank house occupation.

Even though diagnostic attributes can often be used to date glass, not all glass had diagnostic markers, and overlaps in manufacturing methods (Lindsey 2013) make it impossible to positively associate glass artifacts within the plow zone at Meier with one of the two occupations. Another issue with glass recovered from the plow zone, was that glass dating to the later period had what appeared to be intentional flaking. For example, part of an aqua canning jar dating to the later farm occupation at Meier had flaking that resembled a scraper. A similar problem was described in Mallouf (1982), who studied a cache of chert artifacts of which part had been disturbed by plow activity. Mallouf reports that repeated plowing caused a number of different types of damage on almost all of the chert artifacts. Some of this damage was identical to that created by retouch. As a result of the brittle nature of glass compared to other lithic materials (Martindale and Jurakic 2006:416), it is expected that plowing would create many more incidents of breakage and non-human flaking on all glass located within the plow zone at Meier. Only glass from the intact Chinookan plankhouse context is used in this study.

Middle Village's glass assemblage had been previously analyzed (Wilson et al. 2009:331-344), and the data from this earlier analysis was compared to the three sites analyzed by the author. However, in this study glass was removed from the Middle Village sample that came from the later McGowan component and disturbed contexts. 
This was done to remove glass that was not associated with the Chinook occupation and any unintentionally flaked glass created by post depositional formation processes. As a result, the studies' overall sample size was reduced from 1,138 to 536 glass shards; and 23 flake tools and 28 pieces of debitage previously identified were excluded.

\section{Vessel Glass Data Collection}

Glass was analyzed using the same methods as Wilson et al. (2009) used for Middle Village. This analysis followed the Fort Vancouver Laboratory Manual (Wilson et al. 2011:56-61), and its components are summarized in Table 3 below. The small size of the glass fragments from the assemblages did not allow for the minimum number of vessels (MNV) to be determined.

TABLE 3. Variables Recorded For Vessel Glass

\begin{tabular}{ll}
\hline Attribute & Description \\
\hline Weight (g) & Weight of shard, measured in grams \\
\hline Color & Color of shard (ex. amber, amethyst, aqua, etc.). \\
\hline Form & $\begin{array}{l}\text { Type of bottle/glassware or function (ex. bottle, tumbler, } \\
\text { panel bottle, lamp glass, etc.) }\end{array}$ \\
\hline Shape & $\begin{array}{l}\text { Shape of bottle/glassware (ex. cylinder, square/rectangular, } \\
\text { flask, etc.) }\end{array}$ \\
\hline Part & $\begin{array}{l}\text { Portion of bottle/glassware represented (ex. finish, neck, } \\
\text { base, etc.) }\end{array}$ \\
\hline Seam & $\begin{array}{l}\text { Presence or absence of seams associated with manufacturing } \\
\text { method }\end{array}$ \\
\hline Embossed & $\begin{array}{l}\text { Raised print on bottle (ex. maker marks, brand, product } \\
\text { name, etc.) }\end{array}$ \\
\hline $\begin{array}{l}\text { Manufacture } \\
\text { Method }\end{array}$ & $\begin{array}{l}\text { Manufacture technique used to create bottle/glassware (ex. } \\
\text { free blown, mold blown, machine made, etc.) }\end{array}$ \\
\hline $\begin{array}{l}\text { Surface } \\
\text { Modifications }\end{array}$ & $\begin{array}{l}\text { Human modifications or post depositional processes that } \\
\text { altered the glass (ex. burned, scratched, flaked, etc.) }\end{array}$ \\
\hline
\end{tabular}




\section{Identification of Flaked Glass}

Site formation processes create limitations and challenges for identifying flaked glass versus glass flaking by other processes (Martindale and Jurakic 2006:418; Conte and Romero 2008:251-252). A variety of activities, including trampling or natural processes, produce alterations that resemble retouch (Runnels 1976:30; Martindale and Jurakic 2006:417-419; Conte and Romero 2008); which many scholars employ to determine use (Wilkie 1996).

Martindale and Jurakic (2006: 417) recovered a number of glass shards that exhibited potential use as tools at the post-contact Northern Tsimshian site of Ginakangeek, on the north coast of British Columbia. These tools were expediently made and had "a minimum of macroscopic modification". To determine if these glass shards were in fact tools, the authors performed a number of tests. Glass bottles were broken onto a cinder block to observe if any tool-like shards were created. Then glass fragments were trampled on hard packed earth using flat, rubber soled shoes for 100 passes, which equaled approximately 200 footsteps. Lastly Martindale and Jurakic constructed a number of glass artifacts and performed a series of scraping and cutting actions on hide, cordage, and wood; materials which would have been present at the site of Ginakangeek. These specimens were examined under low magnification (10-100x), and types of usewear noted. Martindale and Jurakic argued that higher power microscopes were unnecessary because of glass' properties which made microscopic wear visible at lower magnification with the use of single source oblique lighting. As a result of these experiments, the authors made a number of conclusions. Breaking glass resulted in shards 
with flaking, but it was distinguishable from intentional retouch because of the lack of regularity. Trampling produced "macroscopic pseudo-tools with retouch-like flaking," however this flaking lacked "both the regularity of intentional retouch and the associated microwear pattern derived from use" (Martindale and Jurakic 2006:420). The usewear exercise resulted in a strong association between how the tool was used and the wear pattern. This usewear was distinct from microchipping caused by trampling and other post depositional processes. Overall Martindale and Jurakic's (2006:420) study implied that intentional flaking and microchipping should be distinguishable from post depositional processes by its regularity and unique patterns of usewear.

Conte and Romero (2008) studied an assemblage of glass recovered from Fortlet Minana, Azul, Argentina. In order to determine if the glass that was observed with retouch were human modified, they collected broken glass at several areas around the Universitat Autónoma de Barcelona, which had been exposed to natural and cultural processes e.g., trampling. They then trampled bottle fragments on hard ground to observe the type of modifications to the glass that took place. Last, Conte and Romero used unretouched and retouched tools to scrape different materials, including wood and dry badger hide to observe what types of use wear occurred under high powered magnification (up to 500x). The authors observed a number of instances where trampled glass had scars present which resembled intentional retouch. As a result of these experiments, Conte and Romero (2008:260) argued that glass was "intentionally modified only when their morphology exactly replicates that of a known tool type already in use, but made with other raw materials, or when the use wear traces unmistakably 
indicate that they were used as tools." According to their criteria, only formal glass tools such as projectile points, or expedient tools that showed signs of previously known use wear patterns could be classified as intentionally created tools.

Wilson et al. (2009: 339-340) examined the glass tools and debitage from the Chinook Middle Village. He used a 10x hands lens and did not attempt to identify use wear on tools. Wilson acknowledged the difficulties identifying intentional modification versus breakage caused by post depositional processes as noted in Conte and Romero (2008) and Martindale and Jurakic (2006). However, he noted that it is unlikely that the undisturbed Middle Village assemblage would have been altered by post-depositional processes because of the sandy matrix which made up the house floors and activity areas.

To address these concerns over post depositional processes and the unintentional retouching or microchipping of glass, I conducted two exploratory tests. First I broke a bottle using a rock and then used a wire nail to retouch the edge. I then trampled on glass shards on concrete pavers as well as shards on lightly packed clay rich soil. I wore lightweight shoes and did not attempt to be systematic with my trampling. I found that trampling the glass on concrete pavers created retouch similar to what I could create by flaking the glass. Even with a heavy amount of trampling, I was not able to flake glass or create much microchipping on the glass located on the soil. I speculated that the soil was too wet and not compacted enough to put the stress needed to alter the glass. I cannot make broad claims based on my results, since my tests were not highly rigorous and only intended to get a feel for how trampling could flake glass. However, I venture that some of the glass that Conte and Romero (2008) collected and noted to have intentional 
looking retouch, may have been trampled on concrete or similarly hard surfaces. This is supported by the fact that the glass they collected was around a college campus (Conte and Romero 2008:253). As a result, I am not willing to accept all the results of their study — in favor of the one carried out by Martindale and Jurakic (2006) which replicated conditions closer to the sites in this study.

The sites of Cathlapotle, Meier, and the HBC Village all would have had outside activity areas of packed earth. With the exception of Meier, which had a wooden floor, the interiors of the plankhouses and houses were packed earth (Smith 2004:33-34). As demonstrated by Martindale and Jurakic (2006:420), as well as my exploratory study, trampling on these softer surfaces were not likely to create retouch that would be characterized as intentional. Additionally, the inhabitants at these sites were not wearing shoes (Silverstein 1990:540; Ames 2013, pers. comm.). Periodic cleaning may have also moved sharp glass away from where people walked (Smith 2004:53). If trampling was an issue, I would be able to note it based on random flaking and microchipping (Martindale and Jurakic 2006), as well as the degree and amount of glass surface modifications, such as internal fracturing.

Consequently, Wilson's et al. (2009) method to identify glass flaked tools and debitage was deemed appropriate for this analysis. In addition to the 10x hand lens, I also used lower powered magnification (10-100x), to look for microchipping. This was done mostly to aid my own poor eyesight. 


\section{Flaked Glass Data Collection}

Modified glass was divided into two categories: debitage and tools. These categories were analyzed using separate methods discussed below.

\section{$\underline{\text { Debitage Analysis }}$}

Debitage analysis was based on methods used for analyzing stone debitage (Sullivan and Rosen 1985; Kooyman 2000), and characterized by Byram's (1996, 1998) flake attribute analysis. Debitage attributes indicate the tool production technique, as well as the stage within the reduction sequence (Wilson et al. 2011:62). This methodology "provides information about the particular reduction strategy which may have produced a given flake" (Byram 1998:3). The results of this type of analysis are more reliable at the assemblage level than the individual flake level (Byram 1996; Wilson et al. 2011:62).

Glass debitage was classified according to Sullivan and Rosen’s (1985) hierarchical key, to which Byram (1996) adds bipolar debris. This classification system is outlined in Table 4.

TABLE 4. Debitage Categories and Definitions

\begin{tabular}{ll}
\hline Debitage Type & Description \\
\hline Bipolar & Attributes of bipolar manufacture \\
\hline $\begin{array}{l}\text { Debris or } \\
\text { Core Fragment }\end{array}$ & $\begin{array}{l}\text { No evidence of bipolar reduction, but no single ventral } \\
\text { surface present }\end{array}$ \\
\hline Flake Fragment & Has a single ventral surface, but no platform \\
\hline Broken Flake & $\begin{array}{l}\text { Has a single ventral surface and platform, but incomplete } \\
\text { margins }\end{array}$ \\
\hline Complete Flake & Has a single ventral surface, platform, and intact margins \\
\hline
\end{tabular}


Glass debitage was further divided into four size categories: $\leq 10 \mathrm{~mm} ; 11-19 \mathrm{~mm}$; 20-30mm; and greater than 40mm based on the flake's maximum diameter using Byram's size target. Flakes smaller than 10mm, referred to as Debitage Size 1, were produced by both percussion and pressure flaking. To distinguish between the two, a distinct set of attributes must be noted. These attributes are detailed in Table 5 and Figure 9 below.

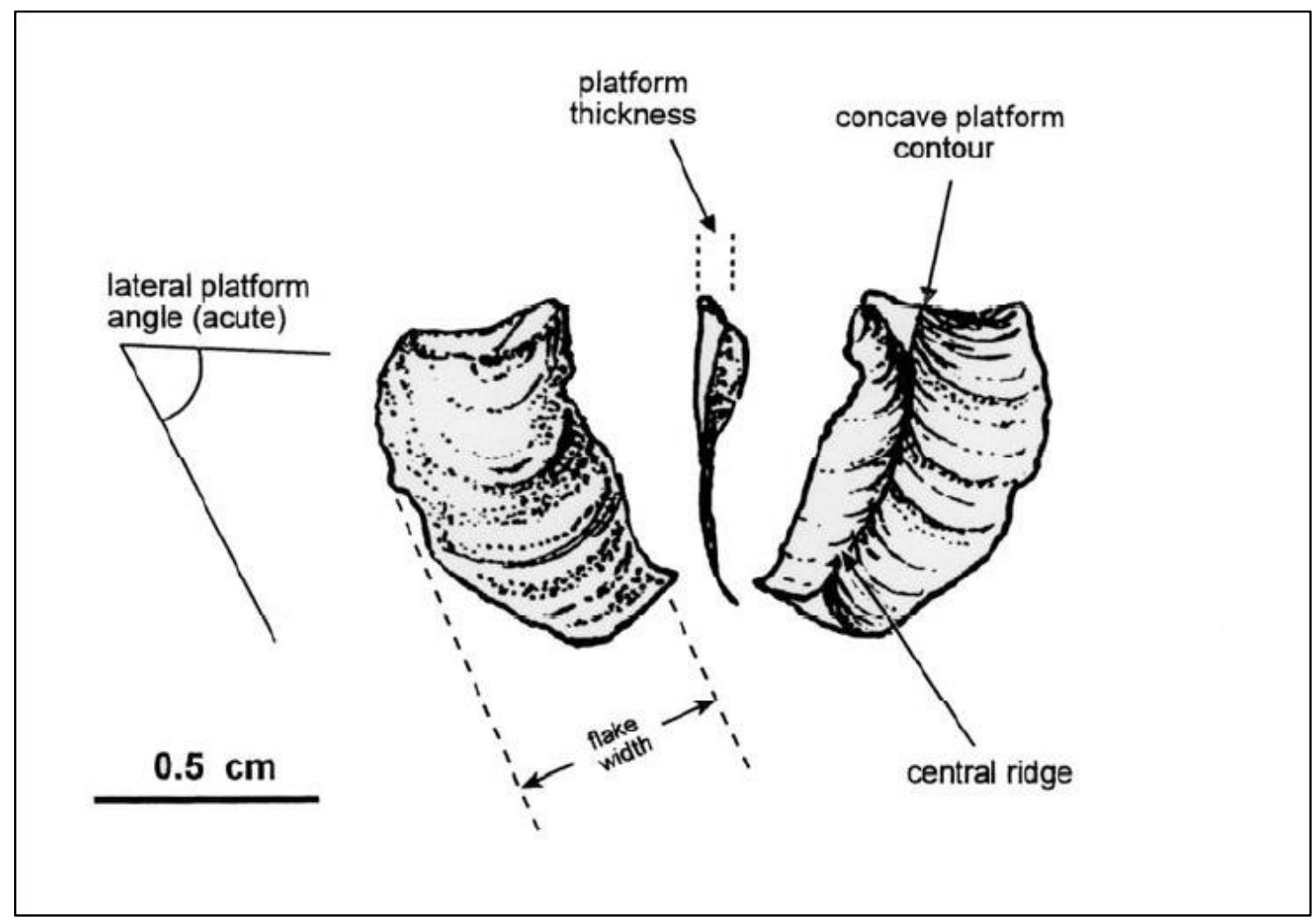

FIGURE 9. Debitage Size 1 Attributes (From Byram 1996:3) 
TABLE 5. Variables Recorded for Debitage Size 1

\begin{tabular}{lll}
\hline Attribute & Category & Description \\
\hline Platform Thickness (mm) & NA & $\begin{array}{l}\text { Thickness of platform measured } \\
\text { between dorsal surfaces }\end{array}$ \\
\hline Platform Contour & $\begin{array}{l}\text { Concave } \\
\text { Convex } \\
\text { Flat }\end{array}$ & Contour of platform's top \\
\hline Platform Angle & NA & $\begin{array}{l}\text { Angle measured in degrees between } \\
\text { the main axis of flake and platform } \\
\text { using an angle gauge }\end{array}$ \\
\hline Width $(\mathrm{mm})$ & NA & \begin{tabular}{l} 
Maximum width of flake \\
\hline
\end{tabular}
\end{tabular}

The classification of complete and broken glass flakes greater than $10 \mathrm{~mm}$, referred to as Debitage Size 2+, is provided in Table 6 below (See also Figure 10).

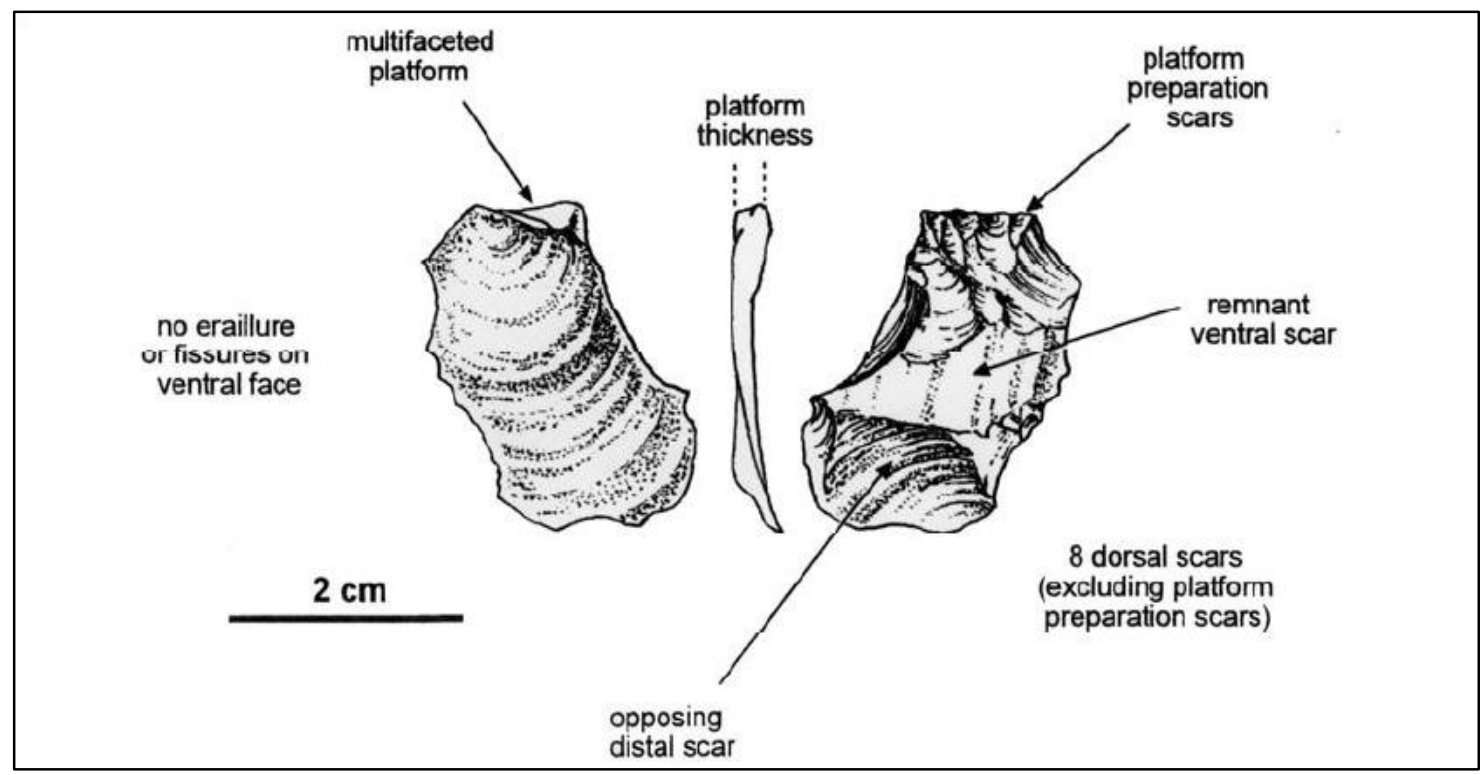

FIGURE 10. Debitage Size 2+ Attributes (From Byram 1996:3) 
TABLE 6. Variables Recorded for Debitage Size 2+

\begin{tabular}{|c|c|c|}
\hline Attribute & Category & Description \\
\hline $\begin{array}{l}\text { Platform Thickness } \\
(\mathrm{mm})\end{array}$ & NA & $\begin{array}{l}\text { Thickness of platform measured between } \\
\text { dorsal surfaces }\end{array}$ \\
\hline Platform Facets & $\begin{array}{l}\text { Single } \\
\text { Multiple } \\
\text { Cortex } \\
\text { Present } \\
\end{array}$ & Flake scars on the platform \\
\hline Number of Dorsal Scars & NA & $\begin{array}{l}\text { Dorsal scars (excluding platform } \\
\text { preparation flakes) greater than } 2 \mathrm{~mm}\end{array}$ \\
\hline \multirow{2}{*}{$\begin{array}{l}\text { Presence of Opposing } \\
\text { Scars }\end{array}$} & Yes & \multirow{2}{*}{$\begin{array}{l}\text { Presence or absence of opposing scars } \\
\text { initiated beyond the distal end of the } \\
\text { flake }\end{array}$} \\
\hline & No & \\
\hline \multirow{2}{*}{$\begin{array}{l}\text { Large Undulations or } \\
\text { Fissures on Ventral } \\
\text { Surface }\end{array}$} & Yes & \multirow{2}{*}{$\begin{array}{l}\text { Presence or absence of pronounced } \\
\text { undulations or fissures on the ventral } \\
\text { surface }\end{array}$} \\
\hline & No & \\
\hline
\end{tabular}

\section{$\underline{\text { Tool Analysis }}$}

Glass tool analysis was based on Jenkins and Connolly (1996). Tools types were classified according to the system developed by Wilson (Wilson et al. 2009:339-343). Table 7 summarizes these tools types, and includes my addition of combination tools used for this study.

All tools except projectile points and bottle abraders were analyzed using the same methodology. Projectile points were analyzed following Wilson et al. (2011:74), and the following measurements were taken in millimeters: length, maximum width, maximum thickness, width at top of neck, and width at base of neck. Projectile points were then classified using Pettrigrew's (1981) typology. For bottle abraders the number of sides and bottle parts with abrasion and scratching were noted. 
TABLE 7. Glass Tool Classification

\begin{tabular}{|c|c|}
\hline Tool Type & Description \\
\hline Projectile Point & Classified with Pettrigrew's (1981) typology. \\
\hline Bottle Abrader & $\begin{array}{l}\text { Bottle bases with no use-wear except abrasion and } \\
\text { scratching. }\end{array}$ \\
\hline Core Tool & $\begin{array}{l}\text { Contains abrasion and scratching, and exhibits use of } \\
\text { one or more edges, possibly used as an abrader. }\end{array}$ \\
\hline Flake Tool & $\begin{array}{l}\text { Intentional retouch or microflaking on one or more } \\
\text { edges. }\end{array}$ \\
\hline Flake Tool Fragment & $\begin{array}{l}\text { Flake tools that showed evidence of the tool being } \\
\text { broken during or after use. }\end{array}$ \\
\hline Possible Flake Tool & \multirow{2}{*}{$\begin{array}{l}\text { Flake tool or fragment for which the evidence is } \\
\text { equivocal to whether it was created by intentional } \\
\text { flaking or post depositional processes. }\end{array}$} \\
\hline $\begin{array}{l}\text { Possible Flake Tool } \\
\text { Fragment }\end{array}$ & \\
\hline Edge Modified Tool & $\begin{array}{l}\text { Glass shards that have been used as tools without } \\
\text { intentional modification. Exhibit systematic, } \\
\text { patterned microchips (defined as } 3 \text { or more, } \\
\text { continuous, adjacent microchips). }\end{array}$ \\
\hline $\begin{array}{l}\text { Edge Modified Tool } \\
\text { Fragment }\end{array}$ & $\begin{array}{l}\text { Edge modified tools that showed evidence of being } \\
\text { broken during or after use. }\end{array}$ \\
\hline $\begin{array}{l}\text { Possible Edge Modified } \\
\text { Tool }\end{array}$ & \multirow{2}{*}{$\begin{array}{l}\text { Edge modified tool or tool fragment for which the } \\
\text { evidence is equivocal to whether it was created by } \\
\text { intentional flaking or post depositional processes. }\end{array}$} \\
\hline $\begin{array}{l}\text { Possible Edge Modified } \\
\text { Tool Fragment }\end{array}$ & \\
\hline Combination & Tools that exhibit signs of multiple tool categories \\
\hline
\end{tabular}

The remaining tool types were each given a unique number to identify it, and each modified edge within the tool its own number. For example, if tool no. 1 had three modified edges, they were numbered 1,2 , and 3 . Then the attributes outlined in Table 8 were recorded for each edge. 
TABLE 8. Variables Recorded for Tool Edges

\begin{tabular}{|c|c|c|}
\hline Attribute & Category & Description \\
\hline \multirow{2}{*}{ Edge Angle } & Narrow & Less than 50 degrees \\
\hline & Broad & Greater than 50 degrees \\
\hline \multirow{2}{*}{$\begin{array}{l}\text { Unifacial or } \\
\text { Bifacial }\end{array}$} & Unifacial & $\begin{array}{l}\text { Flakes removed from only one side of } \\
\text { an edge }\end{array}$ \\
\hline & Bifacial & $\begin{array}{l}\text { Flakes removed from both sides of an } \\
\text { edge }\end{array}$ \\
\hline \multirow{6}{*}{$\begin{array}{l}\text { Edge Shape } \\
\text { (Shape of edge } \\
\text { viewed } \\
\text { between the } \\
\text { edge margin) }\end{array}$} & Excurvate & Bent Outward (Convex) \\
\hline & Incurvate & Bent Inward (Concave) \\
\hline & Irregular & $\begin{array}{l}\text { Neither completely excurvate, } \\
\text { incurvate, or straight }\end{array}$ \\
\hline & Straight & Straight edge which does not bend \\
\hline & Straight to Excurvate & $\begin{array}{l}\text { Goes from straight edge to bending } \\
\text { outward or vice versa }\end{array}$ \\
\hline & Straight to Incurvate & $\begin{array}{l}\text { Goes from straight edge to bending } \\
\text { inward or vice versa }\end{array}$ \\
\hline \multirow{2}{*}{ Abrasion } & Yes & Present \\
\hline & No & Not Present \\
\hline \multirow{2}{*}{ Scratching } & Yes & Present \\
\hline & No & Not Present \\
\hline
\end{tabular}

The attributes of abrasion and scratching are used to determine if a tool is a core tool. The morphological variables of edge angle, unifacial or bifacial, and edge shape all provide information about tool functions (Jenkins and Connolly 1996; Andresky 1998; Kooyman 2000; Wilson et al. 2009). Based on Hamilton's (1994) description of flake tool types at Cathlapotle and Meier, I inferred hypothetical functions for each combination of the three variables discussed above (Table 9). Probable tool function was recorded for each glass tool. However, ethnographic observation and replication/ use 
wear studies have shown that any tool can be used for a variety of purposes (Andresky 1998:4; Kooyman 2000:91), and any conclusions about functions are necessarily tentative.

TABLE 9. Inferred Tool Functions based on Hamilton (1994)

\begin{tabular}{llll}
\hline Face & Edge Shape & Edge Angle & Inferred Possible Functions \\
\hline \multirow{2}{*}{ Straight } & $\begin{array}{l}\text { Broad } \\
\text { Narrow }\end{array}$ & $\begin{array}{l}\text { Scraping } \\
\text { Cutting or Shaving }\end{array}$ \\
\cline { 2 - 4 } Unifacial & \multirow{2}{*}{ Irregular } & $\begin{array}{l}\text { Broad } \\
\text { Narrow }\end{array}$ & Unknown \\
\cline { 2 - 4 } & \multirow{2}{*}{ Excurvate } & Broad & Hide Scraping \\
& Narrow & Shaving \\
\cline { 2 - 4 } & \multirow{2}{*}{ Incurvate } & Broad & Possible Spokeshave \\
& Narrow & Sawing \\
& \multirow{2}{*}{ Straight } & Broad & Cutting \\
\cline { 2 - 4 } & \multirow{2}{*}{ Irregular } & Broad & Unknown \\
& Narrow & Sawing \\
\cline { 2 - 4 } & \multirow{2}{*}{ Excurvate } & Broad & Cutting \\
\cline { 2 - 4 } & \multirow{2}{*}{ Incurvate } & Broad & Possible Spokeshave \\
\cline { 2 - 4 } & & Narrow & \\
\hline
\end{tabular}

\section{Quantitative Methodology}

The small sample sizes of the glass assemblage at Cathlapotle and Meier made it difficult to compare these to Middle Village and the Fort Vancouver Employee Village, which had larger samples. Low sample size could skew percentages.

To facilitate comparison when counts or percentages were not appropriate, areal density was used. Areal density was used rather than volumetrics since it controlled for sites such as Cathlapotle and Meier which have much deeper deposits than those at 
Middle Village and Fort Vancouver Village (Wilson 2013, pers. comm.). The area excavated for each site is given in Table 2 (Chapter 3).

Additionally, the studies' data were examined for normality and outliers, and appropriate statistical tests were performed using the statistical program SPSS. The tests performed and justification for their use is provided in the next chapter on results. 


\section{Chapter 6: Results}

This chapter provides the results of the analysis of vessel glass from Cathlapotle, Meier, and Fort Vancouver, along with a comparison to the previously analyzed Middle Village glass assemblage.

Vessel glass was recovered at all four sites, and Table 10 provides a summary of the amount of vessel glass recovered, and the mean size and standard deviation of the shards. At the Meier Site, 272 glass shards were recovered. However, analysis of this glass determined that there is substantially more mixing and damage from the plow zone than expected. In some cases, $20^{\text {th }}$ century glass was identified within intact Chinookan period contexts which are supposed to be below the plow zone and therefore not mixed. As mentioned in the previous chapter, it is not possible to always distinguish intentional flaking from plow damage. To deal with this issue, all Chinookan period contexts identified as having significant plow activity, based either on stratigraphy or the presence of two or more pieces of modern glass, are omitted from this analysis. After the removal of these contexts, only 24 glass shards or $8.8 \%$ remain from intact deposits. As a consequence, the results of the analysis for Meier provided here are not completely comparable to the other three sites.

The largest amount of glass was recovered from Middle Village. When calculated per square meter, though, Fort Vancouver has the most glass and Cathlapotle the least (excluding Meier). Figure 11 shows that the amount of glass per square meter increased, from Cathlapotle and Middle Village to Fort Vancouver. 
TABLE 10. Total Vessel Glass Recovered and Mean Size

\begin{tabular}{lccc}
\hline \multicolumn{1}{c}{ Site } & $\begin{array}{c}\text { Total Vessel } \\
\text { Glass }\end{array}$ & $\begin{array}{c}\text { Mean Size } \\
(\mathrm{mm})\end{array}$ & $\begin{array}{c}\text { St. Dev. } \\
(\mathrm{mm})\end{array}$ \\
\hline Cathlapotle & 77 & 18.4 & 9.3 \\
\hline Meier & 24 & 14.6 & 5.5 \\
\hline Middle Village & 536 & 24.0 & 14.8 \\
\hline Fort Vancouver & 459 & 20.6 & 10.5 \\
\hline
\end{tabular}

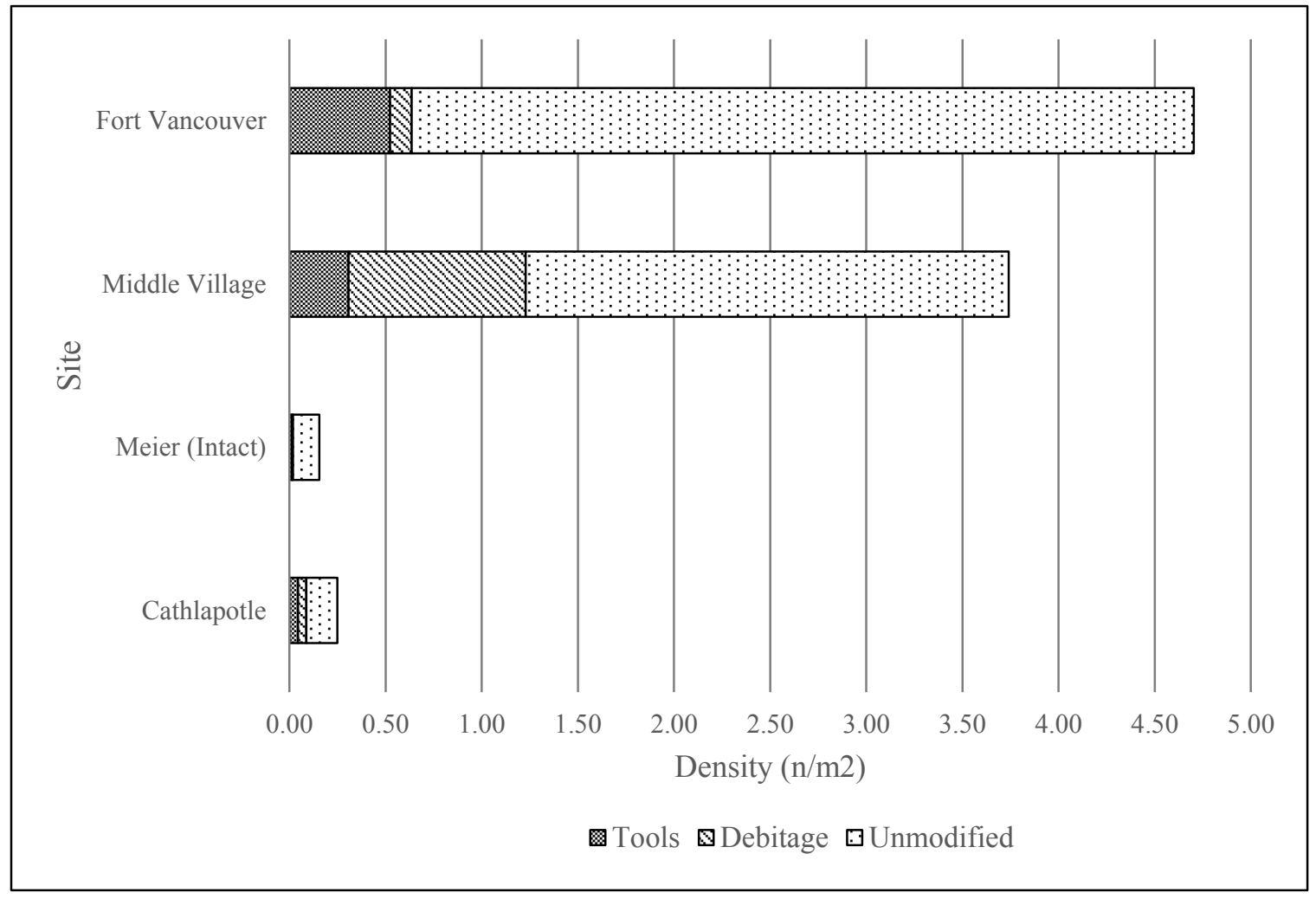

FIGURE 11. Areal Density of Vessel Glass at Four Sites Subdivided by Modification

Size

Of the four sites, Middle Village had the largest mean size of shards, and Meier the smallest (Table 10). When shard size is plotted in Figure 12, Cathlapotle, Middle Village, and Fort Vancouver have fairly similar distributions. In comparison, the majority 
of Meier's glass has a much more narrow spread and is concentrated between size classes 6 and 20.

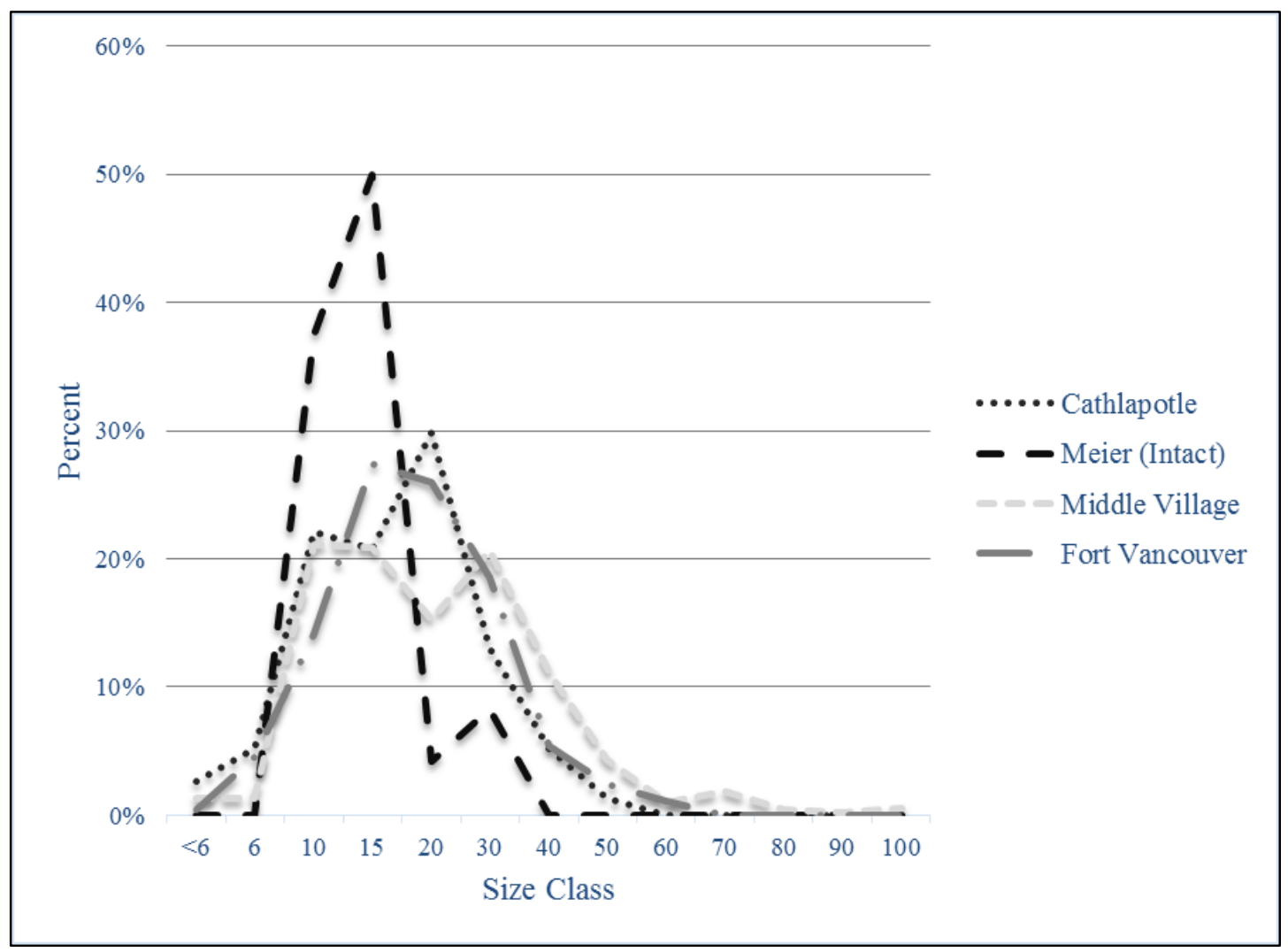

FIGURE 12. Distribution of Vessel Glass Size Classes at Four Sites

To compare the size class distributions at Cathlapotle, Middle Village, and Fort Vancouver, a Kruskal-Wallis test was performed. This test statistic was appropriate as compared to a one way ANOVA since there were outliers in the data, as assessed by inspection of a boxplot, and the data were not normally distributed based on a ShapiroWilk's test of normality $(\mathrm{p}<0.05)$. The Kruskal-Wallis test found that vessel glass shard size was significantly different between the different sites $\left(p<0.05, \chi^{2}=10.450, d f 2, p\right.$ $=.005)$. Pairwise comparisons were then performed using Dunn's procedure with a Bonferroni correction for multiple comparisons. This procedure looks at the data as a 
whole as opposed to running multiple Mann-Whitney tests, which can only compare two groups at time. Post hoc analysis revealed vessel glass size was statistically significantly different between Middle Village and Cathlapotle at the .05 significance level $(p=.016)$, but not between Cathlapotle and Fort Vancouver $(p=.340)$ and Middle Village and Fort Vancouver $(p=.070)$. This confirms that the shards at Middle Village are significantly larger compared to Cathlapotle.

\section{Color}

The majority of the glass at each site, again with the exception of Meier, are green, olive, or dark olive in color (Table 11). These three colors account for $83.1 \%$ of Cathlapotle's glass assemblage, $81.5 \%$ of Middle Village's, and 78\% of Fort Vancouver's. In contrast, at Meier the majority of the glass is colorless (54.2\%). At Cathlapotle and Middle Village, colorless glass is the next largest type. While at Fort Vancouver, aqua and colorless glass make up roughly the same percentage.

TABLE 11.Glass Colors at Study Sites

\begin{tabular}{lcccccccc}
\hline \multirow{2}{*}{ Color } & \multicolumn{2}{c}{ Cathlapotle } & \multicolumn{2}{c}{ Meier (Intact) } & \multicolumn{2}{c}{ Middle Village } & \multicolumn{2}{c}{ Fort Vancouver } \\
& $\mathrm{N}$ & $\%$ & $\mathrm{~N}$ & $\%$ & $\mathrm{~N}$ & $\%$ & $\mathrm{~N}$ & $\%$ \\
\hline Amber & 0 & $0.0 \%$ & 6 & $25.0 \%$ & 2 & $0.4 \%$ & 2 & $0.4 \%$ \\
\hline Colorless & 12 & $15.6 \%$ & 13 & $54.2 \%$ & 79 & $14.7 \%$ & 37 & $8.1 \%$ \\
\hline Aqua & 0 & $0.0 \%$ & 2 & $8.3 \%$ & 10 & $1.9 \%$ & 40 & $8.7 \%$ \\
\hline Cobalt & 1 & $1.3 \%$ & 0 & $0.0 \%$ & 2 & $0.4 \%$ & 0 & $0.0 \%$ \\
\hline Green & 21 & $27.3 \%$ & 1 & $4.2 \%$ & 194 & $36.2 \%$ & 89 & $19.4 \%$ \\
\hline Olive & 33 & $42.9 \%$ & 2 & $8.3 \%$ & 217 & $40.5 \%$ & 152 & $33.1 \%$ \\
\hline Dark Olive & 10 & $13.0 \%$ & 0 & $0.0 \%$ & 26 & $4.9 \%$ & 117 & $25.5 \%$ \\
\hline Ind. & 0 & $0.0 \%$ & 0 & $0.0 \%$ & 6 & $1.1 \%$ & 22 & $4.8 \%$ \\
\hline Total & 77 & & 24 & & 536 & & 459 & \\
\hline
\end{tabular}




\section{Form and Function}

It is often difficult to determine the type/functions of bottles at each site as a result of the small size of glass shards and sometimes lack of diagnostic features. Additionally, before the advent of machine made bottles, bottles were expensive to produce. As a result it was common for bottles to be recycled and filled with products different than what they had originally been produced for (Busch 1987; McDougall 1990:59). Recycling was probably particularly prevalent during the late $18^{\text {th }}$ and early $19^{\text {th }}$ centuries in the Pacific Northwest since bottles were not produced locally. Consequently, even those bottles whose function could be identified may have been reused multiple times for different substances.

The color of glass can sometimes provide clues to what a bottle was used for when there is an absence of diagnostic features. Green, olive, and dark olive colored glass was often used as alcohol bottles during the first half of the $19^{\text {th }}$ century (Wilson et al. 2009:340, Lindsey 2013). As a result, shards of these colors are classified as being from alcohol bottles when no other diagnostic features are present. Colorless glass could come from either bottles or tumblers/tableware and is classified as both when there is a lack of identifiable features.

Table 12 provides the breakdown of glass forms/functions. With the exception of Meier, the majority of glass shards are classified as coming from alcohol related bottle forms, and includes both those bottles classified as alcohol and case bottles, the latter usually made for gin (Lindsey 2013). These alcohol related bottles account for $83.1 \%$ of the assemblage at Cathlapotle, $81.6 \%$ at Middle Village, and $76.3 \%$ at Fort Vancouver. 
Most glass at Meier can only be identified as possibly a bottle or tumbler. Tumbler glass is present at Middle Village (5 shards) and Fort Vancouver ( 3 shards), and there are probably more at all three sites that are unidentified. Shards from panel bottles, which are sometimes used for medicine (Lindsey 2013), are present at all four sites. Lastly, in most instances those shards categorized as "unidentifiable glass type" are glass that has been melted and become amorphous. 
TABLE 12. Vessel Form/Function at Study Sites

\begin{tabular}{lcccccccc}
\hline \multicolumn{1}{c}{ Vessel Form } & \multicolumn{2}{c}{ Cathlapotle } & \multicolumn{2}{c}{ Meier (Intact) } & \multicolumn{2}{c}{ Middle Village } & \multicolumn{2}{c}{ Fort Vancouver } \\
& $\mathrm{N}$ & $\%$ & $\mathrm{~N}$ & $\mathrm{\%}$ & $\mathrm{N}$ & $\mathrm{\%}$ & $\mathrm{N}$ & $\%$ \\
\hline Unid. Bottle & 3 & $3.9 \%$ & 9 & $37.5 \%$ & 25 & $4.7 \%$ & 42 & $9.2 \%$ \\
\hline $\begin{array}{l}\text { Alcohol (Green, } \\
\begin{array}{l}\text { Olive, or Dark Olive } \\
\text { Glass) }\end{array}\end{array}$ & 64 & $83.1 \%$ & 3 & $12.5 \%$ & 435 & $81.2 \%$ & 339 & $73.9 \%$ \\
\hline Case Bottle & 0 & $0.0 \%$ & 0 & $0.0 \%$ & 2 & $0.4 \%$ & 11 & $2.4 \%$ \\
\hline Panel Bottle & 1 & $1.3 \%$ & 2 & $8.3 \%$ & 9 & $1.7 \%$ & 9 & $2.0 \%$ \\
\hline Tumbler & 0 & $0.0 \%$ & 0 & $0.0 \%$ & 5 & $0.9 \%$ & 3 & $0.7 \%$ \\
\hline Tumbler or Bottle & 4 & $5.2 \%$ & 6 & $25.0 \%$ & 26 & $4.9 \%$ & 20 & $4.4 \%$ \\
\hline Unid. Tableware & 0 & $0.0 \%$ & 0 & $0.0 \%$ & 1 & $0.2 \%$ & 2 & $0.4 \%$ \\
\hline Chimney Lamp Glass & 2 & $2.6 \%$ & 0 & $0.0 \%$ & 3 & $0.6 \%$ & 4 & $0.9 \%$ \\
\hline Unid. Glass Type & 3 & $3.9 \%$ & 4 & $16.7 \%$ & 30 & $5.6 \%$ & 29 & $6.3 \%$ \\
\hline Total & 77 & & 24 & & 536 & & 459 & \\
\hline
\end{tabular}




\section{Modified Glass}

The vessel glass analysis results showed that glass at all four sites was intentionally modified as seen in Table 13. The largest number of modified glass fragments occurred at Middle Village $(\mathrm{n}=176)$, followed by Fort Vancouver $(\mathrm{n}=62)$, Cathlapotle $(n=27)$, and lastly Meier $(n=3)$. The greatest proportion of modified glass out of the total glass assemblage was at Cathlapotle (35.1\%), followed closely by Middle Village (32.8\%). Excluding Meier, Fort Vancouver (13.5\%) had the smallest percentage of modified glass.

As shown in Figure 11, above, over time the areal density of modified glass decreased by 0.59 shards per $\mathrm{m}^{2}$ between Middle Village and Fort Vancouver. Between Cathlapotle and Fort Vancouver, however modified glass increased by 0.55 shards per $\mathrm{m}^{2}$. Overall, the proportion of glass that was modified out of the total glass assemblage decreased over time (Table 13).

Fort Vancouver had the largest number of tools $(\mathrm{n}=51)$, as well as the greatest density of tools per square meter $\left(\mathrm{n} / \mathrm{m}^{2}=0.52\right)$. Middle Village $(\mathrm{n}=44)$ had seven less tools than Fort Vancouver, and its areal density was also smaller $\left(\mathrm{n} / \mathrm{m}^{2}=0.31\right)$. Excluding Meier, Cathlapotle $(\mathrm{n}=14)$ had the smallest number of tools, as well as areal density $\left(\mathrm{n} / \mathrm{m}^{2}\right.$ $=0.05)$, but it had the greatest proportion of tools $(18.2 \%)$ to vessel glass overall. Several tools from Meier were obviously intentionally modified, but were excluded from this study since they occurred in the plow zone. 
TABLE 13. Modified Glass, Unmodified Glass, Tools, and Debitage at Sites

\begin{tabular}{|c|c|c|c|c|c|c|c|c|c|c|}
\hline \multirow[b]{2}{*}{ Site } & \multicolumn{3}{|c|}{ Tools } & \multicolumn{3}{|c|}{ Debitage } & \multicolumn{2}{|c|}{$\begin{array}{l}\text { Unmodified } \\
\text { Glass } \\
\% \text { of }\end{array}$} & \multicolumn{2}{|c|}{$\begin{array}{l}\text { Modified } \\
\text { Glass } \\
\% \text { of }\end{array}$} \\
\hline & $\mathrm{N}$ & $\begin{array}{l}\% \text { of } \\
\text { Site's } \\
\text { Total } \\
\text { Glass } \\
\end{array}$ & $\begin{array}{c}\% \text { of } \\
\text { Site's } \\
\text { Modified } \\
\text { Glass } \\
\end{array}$ & $\mathrm{N}$ & $\begin{array}{l}\% \text { of } \\
\text { Site's } \\
\text { Total } \\
\text { Glass } \\
\end{array}$ & $\begin{array}{c}\% \text { of } \\
\text { Site's } \\
\text { Modified } \\
\text { Glass } \\
\end{array}$ & 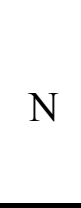 & $\begin{array}{l}\% \text { of } \\
\text { Site's } \\
\text { Total } \\
\text { Glass }\end{array}$ & 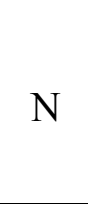 & $\begin{array}{l}\% \text { of } \\
\text { Site's } \\
\text { Total } \\
\text { Glass }\end{array}$ \\
\hline Cathlapotle & 14 & $18.2 \%$ & $51.9 \%$ & 13 & $16.9 \%$ & $48.1 \%$ & 50 & $64.9 \%$ & 27 & $35.1 \%$ \\
\hline Meier & 2 & $8.3 \%$ & $66.7 \%$ & 1 & $4.2 \%$ & $33.3 \%$ & 21 & $87.5 \%$ & 3 & $12.5 \%$ \\
\hline Middle Village & 44 & $8.2 \%$ & $25.0 \%$ & 132 & $24.6 \%$ & $75.0 \%$ & 360 & $67.2 \%$ & 176 & $32.8 \%$ \\
\hline Fort Vancouver & 51 & $11.1 \%$ & $82.3 \%$ & 11 & $2.4 \%$ & $17.7 \%$ & 397 & $86.5 \%$ & 62 & $13.5 \%$ \\
\hline
\end{tabular}


The largest number of pieces of glass debitage occurred at Middle Village ( $\mathrm{n}=$ 132), which also had the greatest areal density $\left(\mathrm{n} / \mathrm{m}^{2}=0.92\right)$. Debitage made up $24.6 \%$ of Middle Village's entire assemblage and $75 \%$ of its modified glass. Cathlapotle $(\mathrm{n}=13)$ and Fort Vancouver $(\mathrm{n}=11)$ had much less debitage than Middle Village, and debitage made up a smaller percentage of the entire glass assemblage at both sites. Additionally, at both Cathlapotle (48.1\%) and Fort Vancouver (17.7\%), debitage made up a smaller proportion of the modified glass than tools in contrast to Middle Village. The difference in debitage amounts is probably related to recovery bias, since except for Middle Village 1/8 in. screen was not used regularly. Consequently, debitage was more likely to be recovered at Middle Village than the three sites.

A chi-square was performed to determine if there was an association between Cathlapotle, Middle Village, and Fort Vancouver and the amount of tools, debitage, and unmodified glass. All expected cell frequencies were greater than five needed to perform the chi-square test (Fletcher and Locke 2005:131). The chi square found that there was a statistically significant association between the different sites and the amount of tools, debitage, and unmodified glass present, $\chi^{2}=105.016, d f 4, p<0.0005$. Table 14 provides the observed and expected counts, and the adjusted residual. The adjusted residual is used instead of the chi-square residual, since for small samples the latter is prone to underestimate the significance of differences. A value of 1.96 or larger indicates that the observed value was significantly larger than the expected, while a value of -1.96 or more indicates that the observed was significantly smaller than expected (VanPool and Leonard 2011:246). 
As seen in Table 14, Cathlapotle had significantly more tools than expected, while there was less unmodified glass than expected. The difference between observed and expected amount of debitage was not significant. Middle Village had both fewer tools and unmodified glass than expected. The difference between observed and expected debitage was significant as well, and there were 54 more pieces of debitage than expected. At Fort Vancouver there was significantly more unmodified glass than expected, but significantly less debitage than expected. The difference between expected and observed amount of tools was not significant.

TABLE 14. Chi-Square Observed and Expected Values, and Adjusted Residuals

\begin{tabular}{clcccc}
\hline \multirow{2}{*}{ Site } & \multicolumn{1}{c}{ Type } & Observed & Expected & $\begin{array}{r}\text { Adjusted } \\
\text { Residual }\end{array}$ & $\begin{array}{c}\text { Significant } \\
\text { (Yes/No) }\end{array}$ \\
\hline \multirow{3}{*}{ Cathlapotle } & Tools & 14.0 & 7.8 & 2.4 & Yes \\
\cline { 2 - 6 } & Debitage & 13.0 & 11.2 & 0.6 & No \\
\cline { 2 - 6 } Middle Village & Unmodified & 50.0 & 58.0 & -2.2 & Yes \\
\cline { 2 - 6 } & Tools & 44.0 & 54.5 & -2.1 & Yes \\
\cline { 2 - 6 } & Debitage & 132.0 & 78.0 & 9.4 & Yes \\
\cline { 2 - 6 } Fort Vancouver & Unmodified & 360.0 & 403.5 & -6.2 & Yes \\
\cline { 2 - 6 } & Tools & 51.0 & 46.7 & 0.9 & No \\
\cline { 2 - 6 } & Debitage & 11.0 & 66.8 & -9.8 & Yes \\
\cline { 2 - 6 } & Unmodified & 397.0 & 345.5 & 7.4 & Yes \\
\hline
\end{tabular}

Location of Glass

The location of vessel glass from Cathlapotle, Meier, and Middle Village was tabulated by count and areal density in terms of its' association with house or midden features. This was done to determine if there was any relationship between the amount of glass (both modified and unmodified) and the status of the household. As previously discussed, Chinookan culture was highly socially stratified based on wealth (Hajda 
1984). Within a village different households/plankhouses had greater status than others, or even within a plankhouse different areas were associated with higher status. The relative status of different households, or in the case of Meier an area within the house, have been determined archaeologically based on the association with higher status goods as well as the size of the house (Smith 2004:27-28; Sobel 2004:607-608; Ames et al. 2011:19). At Cathlapotle, House 1D is interpreted to have been the highest status household, while House 1B is the lowest. Houses 1C and 4 are middle status households (Sobel 2004: 608, 611-612; Ames et al. 2011:19, 41). At Meier, the rear end or the northern section of the plankhouse is the highest status area, and the south end the lowest status (Smith 2004: 28; Ames and Sobel 2013:139-140). While Plankhouse F has the highest status at Middle Village, Plankhouses A and B are lower status (Wilson et al. 2009: 351, 365).

As seen in Table 15, at Cathlapotle the largest areal density of modified glass, unmodified glass, and glass overall occurred in House 1C. House 1B, had the second largest areal density of glass overall. In terms of modified glass, Houses 1B, 1D, and 2 are tied for the second largest amount of modified glass. Houses 1B and 4 had the second largest amount of unmodified glass overall. Based on these trends, it appears that the middle status household of $1 \mathrm{C}$ seems to have acquired the most glass, and is modifying glass more often than other households. The lowest status House 1B and the highest status House 1D are acquiring and modifying similar amounts of glass based on areal density. 
The distribution of glass at Meier is based on the sample of glass undisturbed by the plow zone since glass within the plow zone would have been moved from its original context. As a result, any conclusions must be viewed with caution since the glass sample is only a very small subsample. The greatest areal density of glass overall occurred outside the plankhouse, but not in the midden. Within the house, the greatest areal density of glass was association with the middle portion of the plankhouse (Table 16). The higher and lower end areas of the plankhouse had the same density of glass overall. The sample size of three pieces of modified glass is too small to make any conclusions in terms of the spatial patterning.

TABLE 15. Distribution of Glass at Cathlapotle by Area

\begin{tabular}{lcccccc}
\hline \multicolumn{1}{c}{ Area } & \multicolumn{2}{c}{ Modified } & \multicolumn{2}{c}{ Unmodified } & \multicolumn{2}{c}{ Total } \\
& $\mathrm{N}$ & $\mathrm{N} / \mathrm{M}^{2}$ & $\mathrm{~N}$ & $\mathrm{~N} / \mathrm{M}^{2}$ & $\mathrm{~N}$ & $\mathrm{~N} / \mathrm{M}^{2}$ \\
\hline House 1 Compartment B & 2 & 0.25 & 3 & 0.38 & 5 & 0.63 \\
House 1 Compartment C & 5 & 0.36 & 11 & 0.79 & 16 & 1.14 \\
House 1 Compartment D & 14 & 0.25 & 15 & 0.27 & 29 & 0.52 \\
House 1 Sheet Midden & 2 & 0.17 & 2 & 0.17 & 4 & 0.33 \\
\hline House 2 & 1 & 0.25 & 0 & 0.00 & 1 & 0.25 \\
House 2 Sheet Midden & 0 & 0.00 & 0 & 0.00 & 0 & 0.00 \\
\hline House 4 & 2 & 0.05 & 15 & 0.38 & 17 & 0.43 \\
\hline House 6 & 0 & 0.00 & 0 & 0.00 & 0 & 0.00 \\
House 6 Sheet Midden & 0 & 0.00 & 0 & 0.00 & 0 & 0.00 \\
\hline House 7 & 0 & 0.00 & 0 & 0.00 & 0 & 0.00 \\
\hline Midden Lobe A & 0 & 0.00 & 2 & 0.17 & 2 & 0.17 \\
Midden Lobe B & 0 & 0.00 & 0 & 0.00 & 0 & 0.00 \\
Midden Lobe B/ Basal & 0 & 0.00 & 0 & 0.00 & 0 & 0.00 \\
\hline Total & 26 & & 48 & & 74 & \\
\hline
\end{tabular}


TABLE 16. Distribution of Glass at Meier by Area

\begin{tabular}{lcccccc}
\hline \multirow{2}{*}{ Area } & \multicolumn{2}{c}{ Modified } & \multicolumn{2}{c}{ Unmodified } & \multicolumn{2}{c}{ Total } \\
& $\mathrm{N}$ & $\mathrm{N} / \mathrm{M}^{2}$ & $\mathrm{~N}$ & $\mathrm{~N} / \mathrm{M}^{2}$ & $\mathrm{~N}$ & $\mathrm{~N} / \mathrm{M}^{2}$ \\
\hline North & 0 & 0.00 & 3 & 0.09 & 3 & 0.09 \\
\hline Central & 0 & 0.00 & 4 & 0.20 & 4 & 0.20 \\
\hline South & 1 & 0.02 & 4 & 0.07 & 5 & 0.09 \\
\hline Exterior & 1 & 0.04 & 7 & 0.28 & 8 & 0.32 \\
\hline Midden Area & 1 & 0.03 & 3 & 0.09 & 4 & 0.13 \\
\hline Total & 3 & & 21 & \multicolumn{5}{c}{24} \\
\hline
\end{tabular}

As seen in Table 17, the greatest areal density of total glass in Middle Village occurred in Plankhouse A, a lower status plankhouse. Plankhouse A also had the greatest areal density of modified glass. However, the largest density of unmodified glass occurred in Plankhouse B. Plankhouse F had only slightly less total glass than Plankhouse B, and only slightly less unmodified glass than Plankhouse A. Additionally, Plankhouse F, had more modified glass than Plankhouse B. When debitage and glass tools are separated out (Table 18), the greatest density of tools occur in Plankhouse A. Though, Plankhouses B and F only have slightly less tools per meter square. The vast majority of debitage as measured by areal density occurs in Plankhouse A. Therefore, the majority of glass tools appear to have been produced in Plankhouse A, but used in all three plankhouses. 
TABLE 17. Distribution of Glass at Middle Village by House

\begin{tabular}{lcccccc}
\hline \multirow{2}{*}{ House } & \multicolumn{2}{c}{ Modified } & \multicolumn{2}{c}{ Unmodified } & \multicolumn{2}{c}{ Total } \\
& $\mathrm{N}$ & $\mathrm{N} / \mathrm{M}^{2}$ & $\mathrm{~N}$ & $\mathrm{~N} / \mathrm{M}^{2}$ & $\mathrm{~N}$ & $\mathrm{~N}^{2} \mathrm{M}^{2}$ \\
\hline $\mathrm{A}$ & 66 & 2.57 & 74 & 2.88 & 140 & 5.45 \\
\hline $\mathrm{B}$ & 10 & 0.82 & 37 & 3.05 & 47 & 3.87 \\
\hline $\mathrm{F}$ & 59 & 1.12 & 142 & 2.70 & 201 & 3.82 \\
\hline Total & 135 & & 253 & & 388 & \\
\hline
\end{tabular}

TABLE 18. Distribution of Tools and Debitage at Middle Village by House

\begin{tabular}{lcccc}
\hline \multirow{2}{*}{ House } & \multicolumn{2}{c}{ Tools } & \multicolumn{2}{c}{ Debitage } \\
& $\mathrm{N}$ & $\mathrm{N} / \mathrm{M}^{2}$ & $\mathrm{~N}$ & $\mathrm{~N} / \mathrm{M}^{2}$ \\
\hline $\mathrm{A}$ & 9 & 0.35 & 57 & 2.22 \\
\hline $\mathrm{B}$ & 4 & 0.33 & 6 & 0.49 \\
\hline $\mathrm{F}$ & 16 & 0.30 & 43 & 0.82 \\
\hline Total & 29 & \multicolumn{3}{c}{106} \\
\hline
\end{tabular}

Tools

Tools recovered represented a variety of functions as inferred by edge angle and shape; and Table 19 provides a breakdown of tool types. With the exception of hide scrapers and projectile points, all other tool function categories are expedient tools. 
TABLE 19. Inferred Tool Function by Count and Percent at Study Sites

\begin{tabular}{llccccccc}
\hline \multicolumn{1}{c}{ Tool Function } & \multicolumn{2}{c}{ Cathlapotle } & \multicolumn{2}{c}{ Meier (Intact) } & \multicolumn{2}{c}{ Middle Village } & \multicolumn{2}{c}{ Fort Vancouver } \\
& $\mathrm{N}$ & $\%$ & $\mathrm{~N}$ & $\%$ & $\mathrm{~N}$ & $\%$ & $\mathrm{~N}$ & $\%$ \\
\hline Abrader & 0 & $0.0 \%$ & 0 & $0.0 \%$ & 2 & $4.5 \%$ & 0 & $0.0 \%$ \\
\hline Cutting, Sawing, or Shaving & 1 & $7.1 \%$ & 0 & $0.0 \%$ & 10 & $22.7 \%$ & 6 & $11.8 \%$ \\
\hline Hide Scraper & 1 & $7.1 \%$ & 0 & $0.0 \%$ & 8 & $18.2 \%$ & 3 & $5.9 \%$ \\
\hline Hunting (Projectile Point) & 5 & $35.7 \%$ & 0 & $0.0 \%$ & 1 & $2.3 \%$ & 0 & $0.0 \%$ \\
\hline Multifunction Core Tool & 0 & $0.0 \%$ & 0 & $0.0 \%$ & 5 & $11.4 \%$ & 0 & $0.0 \%$ \\
\hline Multifunction Expedient Tool & 2 & $14.3 \%$ & 1 & $50.0 \%$ & 5 & $11.4 \%$ & 15 & $29.4 \%$ \\
\hline Scraper (Non-Hide) & 1 & $7.1 \%$ & 1 & $50.0 \%$ & 10 & $22.7 \%$ & 12 & $23.5 \%$ \\
\hline Unknown Function Expedient Tool & 4 & $28.6 \%$ & 0 & $0.0 \%$ & 3 & $6.8 \%$ & 15 & $29.4 \%$ \\
\hline
\end{tabular}


The most common tool at Cathlapotle were projectile points used for hunting $(\mathrm{n}=5,35.7 \%)$, while at Middle Village tools used for cutting, sawing, or shaving $(\mathrm{n}=10$, $22.7 \%)$, or non-hide scrapers were the most common $(n=10,22.7 \%)$. Fort Vancouver was dominated by tools that had multiple edges and showed evidence of a variety of different uses $(n=15,29.4 \%)$ as well as tools whose function could not be determined by edge angle and shape $(\mathrm{n}=15,29 \%)$. Middle Village had the most hide scrapers of the four sites $(n=8,18.2 \%)$, followed by Fort Vancouver $(n=3 ; 5.9 \%)$ and Cathlapotle $(n=1,7.1 \%)$. No hide scrapers were recovered at Meier. Projectile points were only recovered at Cathlapotle and Middle Village. Of the six projectile points recovered, only one was recovered at Middle Village. The areal density of each tool function was calculated at the four sites but the resulting values were so small that they are not useful for comparison.

Middle Village had the greatest tool function diversity with all 8 tool function categories represented, followed by Cathlapotle $(n=6)$ and Fort Vancouver $(n=5)$. Middle Village had abraders $(n=2,4.5 \%)$ and multifunction core tools $(n=5,11.4 \%)$ which did not occur at any other site. Research has shown that in some cases the number of different classes of artifacts recovered increases with the more area excavated (Rhode 1988:710-711). In order to determine if the area excavated was related to the number of tool types recovered, the two variables were plotted in relation to each other. Figure 13 shows that there is no linear correlation between the number of tool function types and area excavated, and it can be concluded that these two variables are most likely unrelated. 


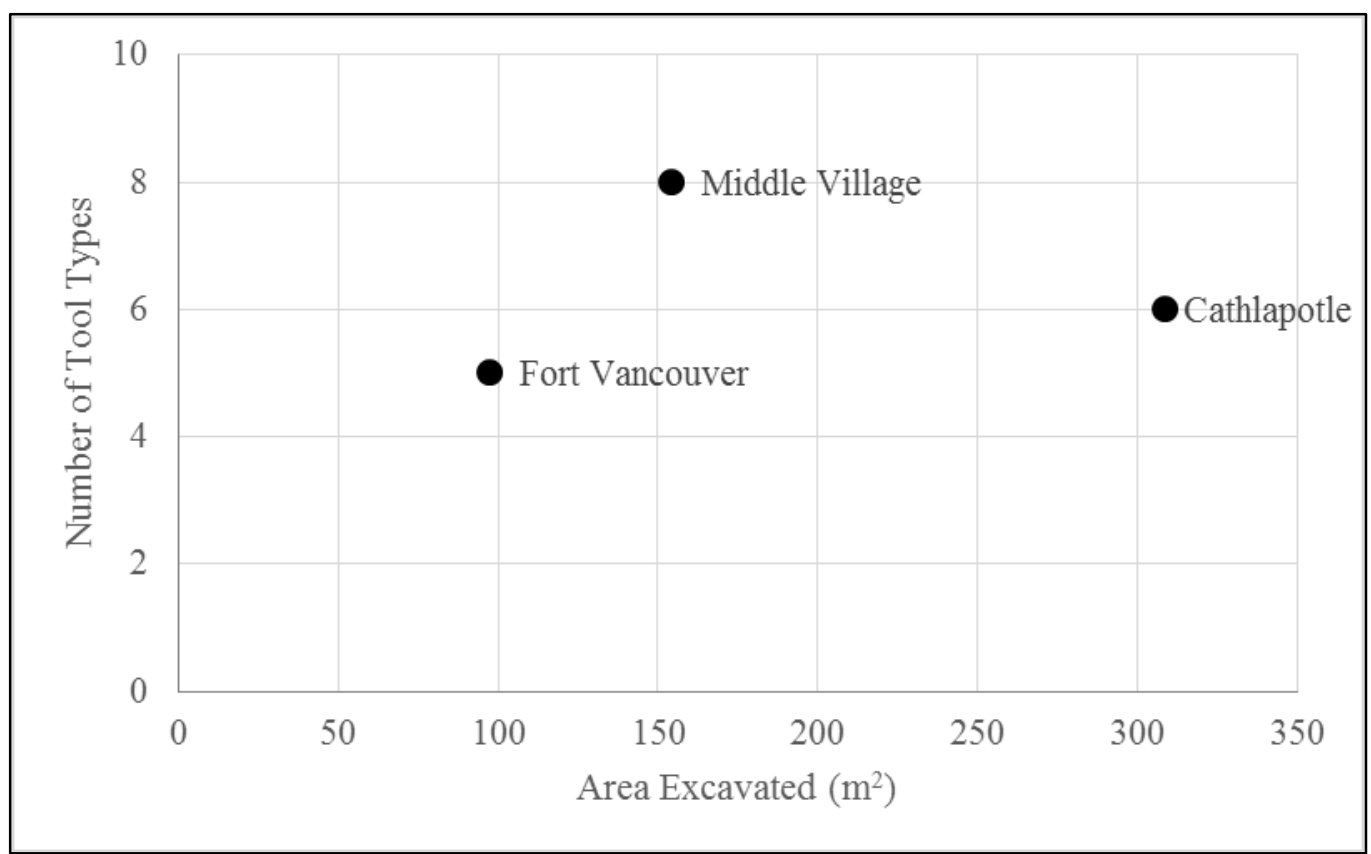

FIGURE 13. Number of Tools Types by Area Excavated

If all four sites are combined, the majority of tool types, $83.8 \%(n=93)$, are classified as expedient. In contrast, 16.2\% $(n=18)$ of all tools represented formal tool types (hide scrapers and projectile points). This pattern continues when each of the sites is looked at individually (Table 20).

TABLE 20. Expedient versus Formal Tools at Study Sites

\begin{tabular}{lcccccc}
\hline \multicolumn{1}{c}{ Site } & \multicolumn{2}{c}{ Expedient Tools } & \multicolumn{3}{c}{ Formal Tools } \\
& $\mathrm{N}$ & $\begin{array}{c}\text { Density } \\
(\mathrm{n} / \mathrm{m} 2)\end{array}$ & $\begin{array}{c}\text { Total } \\
\text { Tools }\end{array}$ & $\mathrm{N}$ & $\begin{array}{c}\text { Density } \\
(\mathrm{n} / \mathrm{m} 2)\end{array}$ & $\begin{array}{c}\text { Total } \\
\text { Tools }\end{array}$ \\
\hline Cathlapotle & 8 & 0.026 & $57.1 \%$ & 6 & 0.019 & $42.9 \%$ \\
\hline Meier (Intact) & 2 & 0.013 & $100.0 \%$ & 0 & 0.000 & $0.0 \%$ \\
\hline Middle Village & 35 & 0.244 & $79.5 \%$ & 9 & 0.063 & $20.5 \%$ \\
\hline Fort Vancouver & 48 & 0.492 & $94.1 \%$ & 3 & 0.031 & $5.9 \%$ \\
\hline
\end{tabular}

As seen in Table 20, not including Meier, Fort Vancouver has the greatest number as well as areal density of expedient tools, while Cathlapotle has the smallest number and 100 
areal density. The majority of tools at Fort Vancouver, $94.1 \%$, are expedient compared to $79.5 \%$ at Middle Village and only $57.1 \%$ at Cathlapotle. In terms of formal tools, Middle Village has the greatest number per square meter and Cathlapotle the least. However, Cathlapotle's small sample size may be skewing this number since by count Cathlapotle has more formal tools than Fort Vancouver and only three less than Middle Village. Additionally, Cathlapotle has the highest percentage of formal tools.

\section{Debitage}

With the exception of Middle Village, only a small amount of debitage was recovered at the study sites (Table 13 and 18). The ratio of glass debitage to glass tools compared to lithic debitage to stone tool ratio is presented in Table 21. Cathlapotle's ratio of glass debitage to tools is very small in contrast to the much larger ratio of lithic debitage to tools. The ratio of glass debitage to tools and lithic debitage to tools are very similar at Middle Village.

TABLE 21. Ratio of Debitage to Tools at Study Sites

\begin{tabular}{lcc}
\hline \multicolumn{1}{c}{ Site } & $\begin{array}{c}\text { Ratio of Glass } \\
\text { Debitage to Tools }\end{array}$ & $\begin{array}{c}\text { Ratio of Lithic } \\
\text { Debitage to Tools* }\end{array}$ \\
\hline Cathlapotle & $0.9: 1.0$ & $5.1: 1.0$ \\
\hline Meier (Intact) & $0.5: 1.0$ & $11.0: 1.0$ \\
\hline Middle Village & $3.0: 1.0$ & $3.1: 1.0$ \\
\hline Fort Vancouver & $0.2: 1.0$ & $* *$ \\
\hline * From Wilson et al. 2009:261 \\
** Data on lithics not available
\end{tabular}

The types of debitage recovered are presented in Table 22. In general each site is dominated by a different type of debitage. At Cathlapotle, broken flakes were the most 
common $(n=8 ; 61.5 \%)$, complete flakes at Middle Village $(n=72,54.5 \%)$, and core fragments or shatter at Fort Vancouver $(n=6, n=54.5 \%)$. The only evidence of bipolar reduction is at Middle Village which has 4 pieces of bipolar debitage.

The majority of debitage at Cathlapotle, Middle Village, and Fort Vancouver fell into Size Class 1 (Table 23). This is suggestive of the later stages of tool manufacture. The mean platform thickness is also consistent with later stages of tool manufacture at Middle Village with relatively thin platforms (Table 24). However, at Cathlapotle there is evidence of both early and later stage tool manufacture. There the Size Class 1 debitage platforms are relatively thin, while the Size $2+$ Class debitage is thicker, consistent with early stage manufacturing. At Fort Vancouver, both Size Class 1 and 2+ platforms are thicker, possibly indicating debitage produced during early stage tool production.

TABLE 22. Debitage Types at Study Sites

\begin{tabular}{lcccccccc}
\hline \multirow{2}{*}{ Type } & \multicolumn{2}{c}{ Cathlapotle } & \multicolumn{2}{c}{ Meier (Intact) } & \multicolumn{2}{c}{ Middle Village } & \multicolumn{2}{c}{ Fort } \\
& $\mathrm{N}$ & $\%$ & $\mathrm{~N}$ & $\%$ & $\mathrm{~N}$ & $\%$ & $\mathrm{~N}$ & $\%$ \\
\hline A (Bipolar) & 0 & $0.0 \%$ & 0 & $0.0 \%$ & 4 & $3.0 \%$ & 0 & $0.0 \%$ \\
\hline $\begin{array}{l}\text { B (Core } \\
\text { Fragment) }\end{array}$ & 1 & $7.7 \%$ & 0 & $0.0 \%$ & 4 & $3.0 \%$ & 6 & $54.5 \%$ \\
\hline $\begin{array}{l}\text { C (Flake } \\
\text { Fragment) }\end{array}$ & 1 & $7.7 \%$ & 0 & $0.0 \%$ & 37 & $28.0 \%$ & 1 & $9.1 \%$ \\
\hline $\begin{array}{l}\text { D (Broken } \\
\text { Flake) }\end{array}$ & 8 & $61.5 \%$ & 1 & $100.0 \%$ & 15 & $11.4 \%$ & 1 & $9.1 \%$ \\
\hline $\begin{array}{l}\text { E (Complete } \\
\text { Flake) }\end{array}$ & 3 & $23.1 \%$ & 0 & $0.0 \%$ & 72 & $54.5 \%$ & 3 & $27.3 \%$ \\
\hline Total & 13 & & 1 & & 132 & & 11 & \\
\hline
\end{tabular}


TABLE 23. Debitage Size Classes at Study Sites

\begin{tabular}{lccccc}
\hline \multicolumn{1}{c}{ Site } & \multicolumn{5}{c}{ Size Class } \\
& $\mathrm{N}$ & $\begin{array}{c}1 \\
\text { Column } \%\end{array}$ & $\mathrm{~N}$ & Column $\%$ & Total \\
\hline Cathlapotle & 8 & $61.5 \%$ & 5 & $38.5 \%$ & 13 \\
\hline Meier (Intact) & 0 & $0.0 \%$ & 1 & $100.0 \%$ & 1 \\
\hline Middle Village & 81 & $61.4 \%$ & 51 & $38.6 \%$ & 132 \\
\hline Fort Vancouver & 6 & $54.5 \%$ & 5 & $45.5 \%$ & 11 \\
\hline
\end{tabular}

TABLE 24. Mean Debitage Platform Thickness for Size 1 and 2+

\begin{tabular}{|c|c|c|c|c|}
\hline \multirow{3}{*}{ Site } & \multicolumn{4}{|c|}{ Size Class } \\
\hline & \multicolumn{2}{|l|}{1} & \multicolumn{2}{|c|}{$2+$} \\
\hline & Mean Size (mm) & $\sigma$ Size $(\mathrm{mm})$ & Mean Size $(\mathrm{mm})$ & $\sigma$ Size $(\mathrm{mm})$ \\
\hline Cathlapotle & 1.02 & 0.44 & 1.50 & 0.84 \\
\hline Meier (Intact) & NA & & 2.55 & NA \\
\hline Middle Village & 0.54 & 0.27 & 1.05 & 0.96 \\
\hline Fort Vancouver & 1.68 & 0.70 & 3.99 & 0.09 \\
\hline
\end{tabular}

The platform contour of Size Class 1 debitage is presented in Table 25. Convex or flat platforms dominate at Cathlapotle and Middle Village, and is indicative of pressure and percussion flaking. The Fort Vancouver debitage represented pressure flaking created with the use of a narrow indentor. However, the sample of Fort Vancouver may be affected by the limited number of flakes with platforms $(n=2)$.

TABLE 25. Platform Contour of Size 1 Debitage

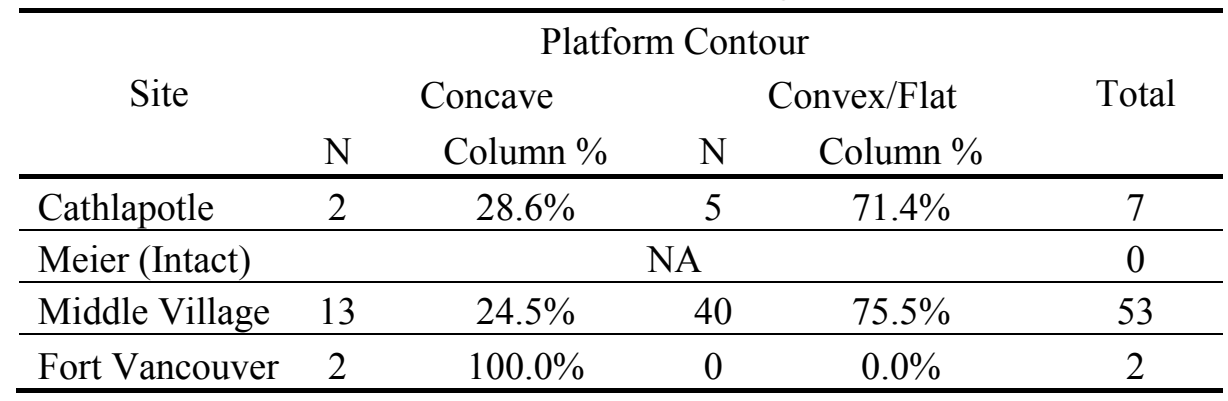


Analysis of Size Class $2+$ debitage indicates that the majority of debitage at Cathlapotle has platforms with multiple facets (Table 26) and opposing scars on the ventral surface (Table 27). Both of these attributes are consistent with middle to late stage biface reduction. In contrast, at Middle Village all platforms have only a single facet (Table 26), while all but one piece of debitage do not have opposing scars (Table 27). These traits suggest early stage unifacial or biface reduction at Middle Village. At Fort Vancouver the dominance of debitage without opposing scars suggests that debitage was produced during early stage reduction (Table 27), though again the sample size may be too small to make any valid conclusion.

TABLE 26. Platform Facets and Cortex of Size 2+ Debitage

\begin{tabular}{lccccccc}
\hline \multicolumn{1}{c}{ Site } & $\mathrm{N}$ & $\begin{array}{c}\text { Single } \\
\text { Column } \%\end{array}$ & $\mathrm{~N}$ & $\begin{array}{c}\text { Multiple } \\
\text { Column \% }\end{array}$ & $\mathrm{N}$ & $\begin{array}{c}\text { Cortex } \\
\text { Column \% }\end{array}$ & Total \\
\hline Cathlapotle & 1 & $25.0 \%$ & 3 & $75.0 \%$ & 0 & $0 \%$ & 4 \\
\hline Meier (Intact) & 1 & $100.0 \%$ & 0 & $0.0 \%$ & 0 & $0 \%$ & 1 \\
\hline $\begin{array}{l}\text { Middle } \\
\text { Village }\end{array}$ & 32 & $100.0 \%$ & 0 & $0.0 \%$ & 0 & $0 \%$ & 32 \\
\hline $\begin{array}{l}\text { Fort } \\
\text { Vancouver }\end{array}$ & 1 & $50.0 \%$ & 1 & $50.0 \%$ & 0 & $0 \%$ & 2 \\
\hline
\end{tabular}

TABLE 27. Presence or Absence of Opposing Scars on Size 2+ Debitage

\begin{tabular}{lccccc}
\hline \multicolumn{1}{c}{ Site } & \multicolumn{2}{c}{ Yes } & \multicolumn{2}{c}{ No } & Total \\
& $\mathrm{N}$ & Column \% & $\mathrm{N}$ & Column \% & \\
\hline Cathlapotle & 3 & $75.0 \%$ & 1 & $25.0 \%$ & 4 \\
\hline Meier (Intact) & 1 & $100.0 \%$ & 0 & $0.0 \%$ & 1 \\
\hline Middle Village & 1 & $3.1 \%$ & 31 & $96.9 \%$ & 32 \\
\hline Fort Vancouver & 1 & $33.3 \%$ & 2 & $66.7 \%$ & 3 \\
\hline
\end{tabular}


At all three sites, the majority of Size $2+$ debitage has no undulations or fissures on its dorsal side, as seen in Table 28. This pattern is associated with the use of preforms rather than flake blanks during tool production.

TABLE 28. Presence or Absence of Undulations and/or Fissures on Size 2+ Debitage

\begin{tabular}{lccccc}
\hline \multicolumn{1}{c}{ Site } & \multicolumn{2}{c}{ Yes } & & No & Total \\
& $\mathrm{N}$ & Column $\%$ & $\mathrm{~N}$ & Column \% & \\
\hline Cathlapotle & 0 & $0.0 \%$ & 4 & $100.0 \%$ & 4 \\
\hline Meier (Intact) & 1 & $100.0 \%$ & 0 & $0.0 \%$ & 1 \\
\hline Middle Village & 4 & $12.5 \%$ & 28 & $87.5 \%$ & 32 \\
\hline Fort Vancouver & 0 & $0.0 \%$ & 3 & $100.0 \%$ & 3 \\
\hline
\end{tabular}




\section{Chapter 7: Discussion and Conclusions}

This chapter discusses the results of this study and how they support or reject the four research hypotheses. It also provides overall conclusions, study limitations, and avenues for future research.

Hypothesis \#1: Vessel glass became a new raw material for the creation of tools at the three Chinookan sites.

Vessel glass was used to create tools at Cathlapotle, Meier, and Middle Village to varying degrees. This adoption of a new raw material for creating tools is an example of creolization and ethnogenesis. Chinookans chose to incorporate vessel glass, a foreign material into their culture, yet they used glass to create traditional tools similar to those they created with stone. Simply put, creolization occurred where this nontraditional material was used in a way that fit into their overarching cultural system. Further, the adoption of glass tools into Chinookan culture illustrates the larger process of ethnogenesis taking place. Glass tools are just one of the infinite phenomenons interacting in what Voss (2008:1) calls a cultural dialogue, all the while creating new cultural identities.

The presence of the unmodified glass itself at Chinookan sites, also reflects the processes of ethnogenesis and creolization. In the case of Middle Village, the amount and size of glass present, suggests that the Chinook there were consuming the new, foreign products which came in these glass containers. At Cathlapotle and Middle Village, alcohol related bottles dominate the assemblages. 
The introduction of alcohol into Native culture, illustrates how contact was not an isolated, short term encounter, but one that Silliman $(2001,2005)$ would describe as full of competing power relations. Fur Traders used alcohol to dominate and manipulate groups such as the Chinookan people in order to gain the economic upper hand in a race for dwindling fur resources (Gibson 1992:225-226). Yet despite the damaging effects of alcohol on Native Peoples, historical accounts suggest that Native groups like the Chinookans were not completely subjugated participants in the fur trade (Cole and Darling 1990:124; Boyd 2011). Chinookans were able to use new formed alliances, their knowledge of the area's natural resources, and many years' experience as traders to sometimes get what was important to them—goods as a means of increasing one's status in society.

Glass itself as a material may have had some value at Cathlapotle. There, glass is significantly more fragmentary than at Middle Village, which along with the relatively small amount of glass may be indicative of glass shards, and not bottles being traded. If glass shards and not bottles and their contents were traded, then perhaps they were traded as raw material for making tools? Or maybe they had worth as an exotic and coveted item? We are culturally conditioned to think of glass fragments as garbage, even dangerous garbage for that matter, and Chinookans may not have viewed glass in the same way. If glass shards were valuable at Cathlapotle, but relatively scarce, then more recycling of glass might be expected. The results of the analysis somewhat supports this scenario. Although Cathlapotle had less modified glass and modified glass per square meter than Middle Village, a greater percentage of its glass was modified compared to 
Middle Village (Table 13). This suggests that with the glass they had, the residents at Cathlapotle were more likely to modify it, perhaps because of its value.

Hypothesis \#2: Changing lifeways as a result of contact and participation in the fur trade economy will result in a glass tool technology that differs from traditional stone tool technology.

This hypothesis must be rejected, as the majority of glass tools are consistent with traditional technologies. Expedient glass tools were used for a variety of scraping, shaving, sawing, and cutting activities, much like the functions of stone tools detailed in Table 29 below for the three Chinookan sites.

Additionally, at Cathlapotle the majority of glass tools are projectile points. This is similar to lithic projectile points, which a make up the majority of the stone tools at this site (Table 29). This pattern may reflect glass' similarity to obsidian, since the most common type of obsidian tool at Cathlapotle were projectile points (Sobel 2004:628).

The fact that the majority of glass tools at the three Chinookan sites reassembled traditional lithic tool technology may indicate that glass was recycled because of its physical properties. If this is the case, then glass was another raw material to be used in replacement of stone. 
TABLE 29. Lithic Tools by Function at Three Chinookan Sites

\begin{tabular}{l|ccc|ccc|ccc}
\hline \multicolumn{1}{c|}{ Tool Type } & \multicolumn{3}{c}{ Cathlapotle } & \multicolumn{3}{c}{ Meier } & \multicolumn{3}{c}{ Middle Village } \\
\hline Biface & $\mathrm{N}$ & $\%$ & $\mathrm{~N} / \mathrm{M}^{2}$ & $\mathrm{~N}$ & $\%$ & $\mathrm{~N} / \mathrm{M}^{2}$ & $\mathrm{~N}$ & $\mathrm{~N} / \mathrm{M}^{2}$ \\
\hline Core & 19 & $0.5 \%$ & 0.06 & 21 & $0.5 \%$ & 0.14 & 0 & $0.0 \%$ & 0.00 \\
\hline Cutter & 1070 & $30.9 \%$ & 3.46 & 1327 & $33.8 \%$ & 8.58 & 4 & $18.2 \%$ & 0.03 \\
\hline Graver & 54 & $1.6 \%$ & 0.17 & 215 & $5.5 \%$ & 1.39 & 0 & $0.0 \%$ & 0.00 \\
\hline Hide Scraper & 19 & $0.5 \%$ & 0.06 & 72 & $1.8 \%$ & 0.47 & 0 & $0.0 \%$ & 0.00 \\
\hline Perforator & 474 & $13.7 \%$ & 1.53 & 169 & $4.3 \%$ & 1.09 & 2 & $9.1 \%$ & 0.01 \\
\hline Projectile Point & 18 & $0.5 \%$ & 0.06 & 32 & $0.8 \%$ & 0.21 & 0 & $0.0 \%$ & 0.00 \\
\hline Saw & 1468 & $42.4 \%$ & 4.75 & 1595 & $40.6 \%$ & 10.32 & 7 & $31.8 \%$ & 0.05 \\
\hline Scraper & 14 & $0.4 \%$ & 0.05 & 33 & $0.8 \%$ & 0.21 & 0 & $0.0 \%$ & 0.00 \\
\hline Shaver & 31 & $0.9 \%$ & 0.10 & 36 & $0.9 \%$ & 0.23 & 1 & $4.5 \%$ & 0.01 \\
\hline Uniface & 243 & $7.0 \%$ & 0.79 & 382 & $9.7 \%$ & 2.47 & 0 & $0.0 \%$ & 0.00 \\
\hline Wedge & 51 & $1.5 \%$ & 0.17 & 28 & $0.7 \%$ & 0.18 & 0 & $0.0 \%$ & 0.00 \\
\hline Undetermined Function & 0 & $0.0 \%$ & 0.00 & 0 & $0.0 \%$ & 0.00 & 8 & $36.4 \%$ & 0.06 \\
\hline Total & 3466 & $100.0 \%$ & 11.22 & 3931 & $100.0 \%$ & 25.43 & 22 & $100.0 \%$ & 0.15 \\
\hline
\end{tabular}


However, it is probably overly simplistic to view glass completely in materialistic terms. Any item can have functionality, while at the same time having deeper meaning or value to its user. Thrush (2011:19) describes this phenomena perfectly in his work, noting how an item "could be both magical and mundane, sacred and secular" simultaneously.

Even though the majority of glass tools at all three Chinookan sites are consistent with traditional lithic technology, at Middle Village some of the glass tools represent changes in tool technology. There are two bottle bases which show evidence of scratching on their base. Wilson et al. (2009:341-342) suggests that this may be related to use as an abrader. Such a tool represents a creative reuse of the glass bottle. In addition, five of the tools (11.4\%) exhibit use on multiple edges for different functions. At Cathlapotle and Meier, the lithic tool technology in general was rather wasteful—-tools were for a single function and discarded after (Hamilton 1994).

Of the three sites, Middle Village also shows the most evidence for the processing of hides. Eight glass hide scrapers were recovered there, compared to only one at Cathlapotle and none at Meier. In contrast, as seen in Table 29, lithic hide scrapers occur in the greatest amounts and densities at Cathlapotle, followed by Meier, and then Middle Village. Glass hide scrapers are further discussed below in Hypothesis \#3. 
Hypothesis \#3: Varied responses to contact and participation in the fur trade economy will result in differences in the amount of vessel glass, modified glass, and glass tool forms/functions between Chinookan sites.

All three Chinookan sites differ in amount of vessel glass, modified glass, and tool forms/functions, though not in the ways they were expected to.

As postulated, Middle Village has the greatest amount of vessel glass as calculated per areal density, while Cathlapotle and Meier have less vessel glass. Given the sample issues at Meier, it is only appropriate to compare Middle Village and Cathlapotle. Access and demand probably factor into why Middle Village has more glass than Cathlapotle. The close proximity of Middle Village to Fort Astoria/George and the mouth of the Columbia where trade vessel's stopped to trade would have provided this group of Chinook direct access to fur trade goods. Of course access could not have been the only factor, since there had to be demand for glass goods at Middle Village.

There may be less vessel glass at Cathlapotle since it was further from the main source of glass on the coast until Fort Vancouver was established inland in 1824. In the early years, manpower and supplies were tight, and by the time the fort was well established in the 1830 s, much of the nearby native population had been decimated by disease (Gibson 1992:69; Boyd 1999:84, 242-245). As a result, even if there had been demand for vessel glass at Cathlapotle, supplies may have been limited.

The differences in the amount of historic artifacts between sites mirrors that of vessel glass as seen Table 30. Middle Village has the greatest density of all historic 
artifact types while Cathlapotle has sustainably less. As discussed above, this may be related to availability as well as control of these resources by upper river Chinookans.

TABLE 30. Trade Goods at Three Chinookan Sites

\begin{tabular}{l|cc|cc|cc}
\hline \multirow{2}{*}{ Artifact Type } & \multicolumn{2}{c|}{ Cathlapotle } & \multicolumn{2}{c|}{ Meier } & \multicolumn{2}{c}{ Middle Village } \\
& $\mathrm{N}$ & $\mathrm{N} / \mathrm{M}^{2}$ & $\mathrm{~N}$ & $\mathrm{~N} / \mathrm{M}^{2}$ & $\mathrm{~N}$ & $\mathrm{~N} / \mathrm{M}^{2}$ \\
\hline Glass Beads & 704 & 2.28 & 49 & 0.32 & 662 & 4.62 \\
Ceramics* & 33 & 0.11 & 32 & 0.21 & 364 & 2.54 \\
Clay Tobacco Pipe & $(16)$ & $(0.05)$ & $(9)$ & $(0.06)$ & $(117)$ & $(0.82)$ \\
Copper Artifacts & 119 & 0 & 2 & 0.01 & 14 & 0.10 \\
Metal Projectile Points & 11 & 0.04 & 7 & 0.05 & 3 & 0.02 \\
Metal Tools & & & & & & \\
(Knives, Swords, Awls, & 4 & 0.01 & 0 & 0 & 14 & 0.10 \\
Wedges, and Adzes) & & & & & & \\
Ball and Shot & 8 & 0.03 & 2 & 0.01 & 75 & 0.52 \\
Gun Flints & 1 & 0.003 & 0 & 0 & 15 & 0.10 \\
Vessel Glass & 77 & 0.25 & $24 * *$ & 0.16 & 536 & 3.74 \\
\hline
\end{tabular}

* MNV is represented in parentheses

** Glass from undisturbed contexts

The hypothesis that Cathlapotle and Meier would have the largest amount of modified glass (both in terms of areal density and percentage of total glass) was only partially supported. Cathlapotle had a greater percentage of its glass that was modified compared to Middle Village however Middle Village had a greater areal density of modified glass. 
Cathlapotle may have a larger percentage of modified glass than Middle Village because it was a valued item and scarcity, as discussed in Hypothesis \#1. Further, the scarcity of glass at Cathlapotle is probably why the areal density of modified glass is substantially smaller here than at Middle Village.

In contrast, modified glass may be so common per square meter at Middle Village simply because there was so much more glass available to make tools. Further, glass at Middle Village may have been viewed less as an exotic or special item, but rather as a raw material which could be recycled and used like stone. This conclusion is supported when the lithic and glass assemblages at Middle Village are viewed together rather than separately. Glass debitage makes up approximately $32 \%$ of all debitage (lithic and glass tools combined) and glass tools make up 33\% of all tools (lithic and glass tools combined). This is surprisingly high given that at Cathlapotle, glass debitage and tools both make up less than one percentage of their respective groups.

The premise that there would be differences in the amount of tool types, most specifically scrapers used to produce clamons was not supported. Middle Village and not Cathlapotle has the greatest number of hide scrapers. Cathlapotle only has one hide scraper compared to the eight at Middle Village; and no hide scrapers are present at Meier (though this may be the result of the very low sample size).

One possible explanation may relate to what type of raw material was considered appropriate or proper for use as hide scrapers. As noted in Sobel (2004), very few hide scrapers were produced with obsidian at Cathlapotle —a material similar in physical 
properties to glass. Therefore Chinookans at Cathlapotle may not have viewed glass as something to be used for the construction of hide scrapers. Or the glass at Cathlapotle may have simply been too small to effectively use as a scraper. In contrast to Middle Village, most of Cathlapotle's glass was relatively small in size.

However, at Middle Village, there were a number of hide scrapers. This may be related to the larger size of glass sherds there. Another possible explanation is that at Middle Village perceptions about what materials could be used for tools changed.

Still, glass tool assemblages at all three sites are dominated by expedient tools (or in the case of Cathlapotle-projectile points as well). These types of tools are consistent with traditional stone tool technology. In this manner at a regional scale there is a continuation of stone tool technology. Yet, changes in the tool technology are present at Middle Village with the appearance of bottle base abraders and multiple use tools.

Although not tested as part of this hypothesis, the location of glass in terms of household status differed somewhat between sites. At all three sites, the majority of glass was not associated with the highest status household, but with middle or lower status households.

At Cathlapotle, the largest amount of modified and unmodified glass occurred in the middle status House 1C. While both the lowest status House 1B and the highest status House 1D were acquiring and modifying similar amounts of glass. Interestingly, in terms of trade goods, House 1B followed by House 1D had the largest amount of trade goods. 
House 1C, where the majority of glass occurred, had the smallest amount of trade goods. This may indicate that glass was viewed differently than other trade goods.

At Meier, the sample size is too small to make any strong conclusions about the association of glass with status. Overall, the greatest amount of glass occurred outside the plankhouse in sheet middens, and not in the larger midden. Of the glass that was present inside the plankhouse, the greatest amount was found in the middle portion associated with middle status.

At Middle Village, the majority of glass as well as the majority of modified glass occurred in Plankhouse A, which was one of the lower status plankhouses. The other low status Plankhouse B had the greatest amount of unmodified glass. Based on debitage, it appears that tools were created in Plankhouse A, possibly with glass acquired from Plankhouse B. In terms of tool use, all three households (low and high status) were using around the same amount of glass tools.

Hypothesis \#4: Over time from Chinookan villages to the new fur trade culture at the $H B C$ Village which contained inhabitants from many different cultures, it is expected that the amount of vessel glass will increase; while the amount of modified glass tools will decrease; and glass projectile points will disappear completely from the archaeological assemblage.

Part of Hypothesis \#4, that there would be an increase in the amount of vessel glass overtime and glass projectile points would disappear from tool assemblages was supported. However, there was no evidence that modified glass tools always decreased over time, and in some cases the opposite occurred. 
The HBC Village at Fort Vancouver, has the greatest areal density of glass of all four sites. This is consistent with European goods increasing through time in the region, as well as the HBC Village's very close proximity to such goods. Surprisingly, the areal density of glass at the Employee Village is not that much higher than Middle Village. This may be the result of the high prices the HBC charged its employees (Cromwell 2006:125,127-128). Or possibly some products such as alcohol were really not that readily available to the HBC's employees, as claimed by John McLoughlin in his letters to the HBC governing committee in London (Rich 1941:79; Ross 1976: 1352). Given that much of the glass at the Fort Vancouver Village appears to be alcohol related, the former explanation is more plausible.

The Fort Vancouver Employee Village has a much higher frequency and areal density of modified glass than at Cathlapotle and Meier, but has less modified glass (by both measures) compared to Middle Village. Interestingly, though, Fort Vancouver has more tools by count and areal density than Middle Village, but far less debitage. The chi square found that there was significantly less debitage at Fort Vancouver than was expected. It is probable that if there was debitage, it fell through the $1 / 4 \mathrm{in}$. screen, or that tools were not produced in the area used for the sample. The fact that the largest number of tools occur at Fort Vancouver suggests that although metal tools were readily available there, their price may have made recycling glass a better alternative. This can be viewed as a type of resistance to the HBC's economic hegemony, in the sense that villagers chose not to participate in certain parts of the HBC economy. 
Last, no glass projectile points were recovered from the HBC Employee Village. The rations provided by the HBC to their employees were probably not sufficient to feed a whole family. Consequently, Village residents must have supplemented their rations by other means (Wilkes 1845:329-330; Hussey 1972:52; Roulstone 1975:86-87). The lack of glass projectile points suggests that residents likely used firearms for hunting, or supplemented their diet with domesticated animals or riverine resources such as salmon. After all, riverine fish were such an important regional food source for Chinookan and other local groups (Butler and Martin 2013:104) that it might have continued to be for Village residents.

\section{Overall Conclusions}

Contact and colonization altered the world of Native Peoples, including the Chinookan peoples. During this time, the introduction of new, foreign materials like glass "provided a novel suite of items for use" (Silliman 2001:196). This study has demonstrated that Chinookans modified glass into tools. Further, the use of glass to produce tools is an example of entanglement, where a material is recontextualized into something new. In this case, glass becomes a raw material appropriate for use as a tool. The creation and use of glass tools also represents the process of ethnogenesis. Since by incorporating a foreign material into their toolkit, Chinookans are changing what materials can be used to create tools in their culture - thus changing the larger cultural system.

Importantly there was variation in the degree to which glass was modified and the types of tools that were produced between sites. Some of these differences are probably 
related to availability, how glass was conceptualized by Native People, or other unidentified causes. The multiple factors that created this variation are an example of Voss' (2008:5) overdetermination where many interacting phenomena lead to ethnogenesis.

This study suggests that in some ways glass was just another raw material, similar to stone, that was used to create tools that mirrored the existing lithic technology. However at Cathlapotle at least, glass appears to have been relatively scarce and perhaps valued even as a status item. For the residents of Cathlapotle, glass may have been both mundane and exotic simultaneously, rejecting Anglo American dichotomies of either-or. While at Middle Village, glass (as opposed to stone) is being used about a third of the time to produce tools. Glass at Middle Village is not replacing stone, but rather is complementing it - a type of creolization and hybridity.

Glass tool technology at Cathlapotle, Meier, and Middle Village was very similar to the existing stone technology dominated by expedient/low energy tools; though novel new bottle abraders do appear at Middle Village. This multifaceted response reflects how some traditional lifeways continued, while at the same time new materials and technology was recontextualized in ways that made sense to Chinookan peoples.

This should not be taken to mean that contact had little impact on Chinookans. The devastating effects of disease epidemics have been discussed and the degree of glass from alcohol related bottles shows how fur traders attempted to subjugate Native Peoples. 
Additionally, read critically, historical sources make it all too clear how cultural misunderstandings and violence was not uncommon from either side.

Glass tools (as opposed to both debitage and tools) increase rather than decrease through time. This response appears to be a type of resistance to the HBC's economic hegemony and rigid social structure. Though it is impossible to know if such resistance was consciously acted on or just part of everyday activities that made sense in the economic climate of the time.

Those individuals who made these glass tools may have been Chinookan, but they could just as likely have been one of the other numerous cultural groups or ethnicities that lived in the Village. Glass studies have shown that working glass into tools is not done by just one group — but many different ones. Further distinct, separate cultures do not exist in instances of colonization (Wolf 1982; Silliman 2005). It is better to envision that "individuals walk the fine, often painful, line between old ways and new directions, past practices and future hopes, dangerous times and uncertain outcomes" (Silliman 2005:61). The Village is better understood this way than as being made up of separate, self-contained cultural groups.

Thus far, the majority of modified glass studies have concentrated simply on identifying the presence of glass tools (Runnels 1975, 1976), or explaining them simply in terms of their physical properties (Clark 1981; Kehrberg 1992; Robbin et al. 2004; Conte and Romero 2008). This study goes farther, and like Harrison (2003) and Martindale and Jurakic (2006) attempts to identify the broader historical processes taking 
place in the context of contact and colonization. I will not however make any assumptions what glass tools symbolically meant to the Chinookans, like Harrison (2003) did with the Aboriginal Australians. Such conclusions are beyond the reach of this analysis' archaeological data. This work, though, does fit into Martindale and Jurakic's (2006) study. Chinookans like the Tsimshian, incorporated vessel glass into their cultural framework in ways that made sense to their culture. Additionally, how vessel glass was and was not used is one aspect of a complex web of different factors and responses leading to cultural change.

Overall this study illustrates the very complexity of studying ethnogenesis, because of the infinite interacting phenomena. There are no simple cause and effect, but multiple lines of explanation, of which vessel glass represents one small part. Still, a mundane object such as vessel glass can provide a wealth of information about how groups like the Chinookans dealt with a changing world, or how the multiethnic community at Fort Vancouver dealt with the hegemony of the Hudson Bay Company. Chinookan peoples and the later inhabitants of the Fort Vancouver Employee Village responded to colonization in ways that led to both continuity and change across time.

\section{Research Limitations}

A number of factors created research limitations for this study. Sample size particularly was an issue. Compared to Middle Village, Cathlapotle and Meier did not have as much glass. For Meier, this made it difficult, if not impossible, to compare assemblages. As a result, percentages were sometimes used, but these may not accurately represent the population as result of small sample size. 
Formation processes are extremely important considerations when it comes to identifying intentionally modified glass versus that caused by accidental retouch (Runnels 1976; Vaughn 1981; Martindale and Jurakic 2006; Conte and Romero 2008).

Unfortunately plow activity at Meier made it difficult to distinguish modified glass from plow damaged glass. Mixing created from the plow zone meant that younger glass could not always be identified from older glass. In addition, the plow damaged glass in ways that mirrored intentional retouch. To deal with this issue, I removed all glass within the plow zone from this study. As a result, so little glass was left that it is probably not a representative sample of the original assemblage.

Different methods in how sites were excavated also produced limitations on the type of information that could be learned. Only at Middle Village, was all excavated sediment consistently screened through $1 / 8$ in. mesh screen. The lack of debitage at Cathlapotle, Meier, and Fort Vancouver, appears to indicate that screen size was an important factor in the amount of debitage recovered. With so little debitage recovered at three of the four sites, it was difficult to make any overall conclusions at about how glass tools were produced at these sites.

Inter observer bias is another important factor. I chose not to go through the already analyzed modified glass from Middle Village. As a result it is possible that what I interpreted as modified glass would not have been interpreted as modified by Wilson, who analyzed that assemblage. Hopefully this error factor was lessoned by frequent questions at the beginning of the analysis to whether a glass shard could be considered as 
modified or not. Furthermore, identical techniques and methods designed to reduce inter observer error were used.

Another issue with this study is that it based glass tool function on the morphology of known lithic tool types. This methodology may have led to incorrect interpretations about a tool's function. Glass tool types may not be analogous to the known function of lithic tool types. Additionally, any tool can be used for a variety of purposes, and as a result glass tool shape may have had no relation to tool function. Both of these issues could be remedied in a future study by performing use-wear analyzes that are based on experiments correlating use-wear on glass tools with a given function.

Finally, this studies research questions were based on the assumption that at the three Chinookan villages, only Chinookan residents created and produced glass tools. However, slaves from a number of different groups other than the Chinookans lived at these villages. This analysis does not address the fact that non-Chinookan peoples may have produced and used tools in ways that differed from Chinookan peoples. Future research will need to find a way to remedy this shortcoming.

\section{Future Avenues of Study}

Modified glass is only beginning to be studied, and there are probably countless assemblages with modified glass that have never been identified. Previous studies of modified glass have shown just how much potential it has for answering questions about economics, resistance, and identity—and there are many other research areas it could contribute to. 
One of these research areas is gender, which this study was not able to address. As Voss (2008) has demonstrated in her work, gender cannot be ignored since it plays a prominent role in the construction of identity. Unfortunately, it is unknown whether it was women or men, or both who produced and used glass tools at all four sites. Further ethnographic and historical research may be able to clarify this, and gender should be incorporated into any future studies of flaked glass.

There is also potential for the study of modified glass at contact period Chinookan and other Native sites in the region. Historical artifacts have been recovered from some of these sites, but only a handful of studies have looked for modified glass (Wilson et al. 2009). Analysis of glass recovered from these contact sites can provide a better regional picture of how Native Peoples responded to contact and the introduction of new goods. 


\section{References}

Acheson, Steven and James P. Delgado

2004 Ships for the Taking: Culture Contact and the Maritime Fur Trade on the Northwest Coast of North America. In The Archaeology of Contact in Settler Societies, Tim Murray, editor, pp. 48-77. Cambridge University Press, Cambridge, MA.

Ames, Kenneth M.

1994 The Northwest coast: Complex Hunter-Gatherers, Ecology, and Social Evolution. Annual Review of Anthropology 23: 209-220.

2001 Slaves, Chiefs, and Labor on the Northern Northwest Coast. World Archaeology 33(1): 1-17.

2002 Going by Boat: The Forager-Collector Continuum at Sea. In Beyond Foraging and Collecting: Evolutionary Change in Hunter-Gatherer Settlement Systems, Ben Fitzhugh and Junko Habu, editors, pp. 17-50. Kluwer/Plenum Press, New York, NY.

Ames, Kenneth M. and Herb Maschner

1999 Peoples of the Northwest Coast: Their Archaeology and Prehistory. Thames and Hudson Ltd, London, UK.

Ames, Kenneth M., Doria F. Raetz, Stephen Hamilton, and Christine McAfee.

1992 Household Archaeology of a Southern Northwest Coast Plank House. Journal of Field Archaeology 19(3): 275-290.

Ames, Kenneth M., Cameron M. Smith, William L. Cornett, Stephen C. Hamilton, Elizabeth A. Sobel, John Wolf, and Doria Raetz

1999 Archaeological Investigations at 45CL1 Cathlapotle (1991-1998), Ridgefield Wildlife Refuge, Clark County, Washington; A Preliminary Report. U.S.D.A. Fish and Wildlife Service, Region 1, Cultural Resource Series No. 13, Portland, OR.

Ames, Kenneth M., Cameron M. Smith, and Alexander Bourdeau 2008 Large Domestic Pits on the Northwest Coast of North America. Journal of Field Archaeology 33(1): 3-18.

Ames, Kenneth, Cameron Smith, Greg Baker, and William Gardner-O’Kearny

2011 Chinookan Households on the Lower Columbia River: Contact and Complexity, Grant RZ-50601-06. Report to the National Endowment for the Humanities, Washington, D.C, from the Department of Anthropology, Portland State University, Portland, OR. 
Ames, Kenneth M. and Elizabeth A. Sobel

2013 Houses and Households. In Chinookan Peoples of the Lower Columbia, Robert Boyd, Kenneth M. Ames, and Tony A. Johnson, editors, pp. 125-145. University of Washington Press, Seattle, WA.

Ammerman, Albert J.

1985 Plow-Zone Experiments in Calabria, Italy. Journal of Field Archaeology 12(1):33-40.

Andrefsky, William, Jr.

1998 Lithics: Macroscopic Approaches to Analysis. Cambridge University Press, Cambridge, UK.

Banach, Patricia K.

2002 Copper on the Pacific Northwest Coast. Master's Thesis, Department of Anthropology, Portland State University, Portland, OR.

Barker, Burt Brown (editor)

1948 Letters of Dr. John McLoughlin: Written at Fort Vancouver 1829-1832. Binfords \& Mort, Portland, OR.

Barrett, John C.

2000 A Thesis on Agency. In Agency in Archaeology, Marcia Ann Dobres and John

Robb, editors, pp. 61-68. Routledge, New York, NY

Bell, Edward

1932 Columbia River Exploration 1792, Excerpt from Edward Bell's Journal. J.

Neilson Barry, editor. Oregon Historical Quarterly 33(1):31-42, (2):143-150

Bergmann, Mathias D.

2008 "We Should Lose Much by Their Absence": The Centrality of Chinookans and Kalapuyans to Life in Frontier Oregon. Oregon Historical Quarterly 109(1):34-59.

Bleed, Peter

1986 The Optimal Design of Hunting Weapons: Maintainability or Reliability American Antiquity 51(4): 737-747.

Blanton, R.E., G.M. Feinman, S.A. Kowalewski and P.N. Peregrine 1996 A Dual-Processual Theory for the Evolution of Mesoamerican Civilization. Current Anthropology 37(1): 1-14.

Bloemker, James D. and Carey B. Oakley 1999 The Firebreak Plow and Subsurface Site Discovery. Journal of Field Archaeology 26(1):75-82. 
Boas, Franz.

1894 Chinook Texts. Bureau of American Ethnology Bulletin 20. Smithsonian Institution, Washington, DC.

Bourdieu, Pierre

1977 Outline of a Theory of Practice. Cambridge University Press, Cambridge, MA

Boyd, Robert

1999 The Coming Spirit of Pestilence: Introduced Infectious Diseases and Population

Decline Among Northwest Coast Indians, 1774-1874. University of Washington \& UBC

Presses, Seattle, WA.

2011 Cathlapotle and Its Inhabitants 1792-1860. U.S. Fish and Wildlife Service, Region 1 Cultural Resource Series No. 15, Portland, OR.

Boyd, Robert, Kenneth M. Ames, and Tony A. Johnson (editors)

2013 Chinookan Peoples of the Lower Columbia. University of Washington Press, Seattle, WA.

Bray, Tamara

1984 Ethnic Differences in the Archaeological Assemblages at Kanaka Village. In Report of Investigations at Kanaka Village Vancouver Barracks, Washington 1980/1981, Bryn Thomas and Charles Hibbs, editors, pp.815-831. Report to the Washington State Department of Transportation, from Archaeological and Historical Services, Eastern Washington University Archaeological and Historical Services, Cheney, WA.

Burley, David V.

1989 Function, Meaning and Context: Ambiguities in Ceramic Use by the Hivernant Metis of the Northwestern Plains. Historical Archaeology 23(1): 97-106.

2000 Creolization and Late Nineteenth Century Métis Vernacular Log Architecture on The South Saskatchewan River. Historical Archaeology 34(3):27-35.

Burley, David V., Gayel A. Horsfall and John D. Brandon 1992 Structural Considerations of Métis Ethnicity: An Archaeological, Architectural, and Historical study. University of South Dakota Press, Vermillion, SD.

Burley, Edith I.

1997 Servants of the Honourable Company: Work, Discipline, and Conflict in the Hudson's Bay Company, 1770-1870. Oxford University Press, Toronto, ON.

Busch, Jane

1987 Second Time Around: A Look at Bottle Refuse. Historical Archaeology 21(1):6780. 
Butler, Virginia L.

2002 Fish Remains from Cathlapotle: Preliminary Report. Manuscript, Department of Anthropology, Portland State University, Portland, OR.

Butler, Virginia L. and Michael A. Martin

2013 Aboriginal Fisheries of the Lower Columbia River. In Chinookan Peoples of the

Lower Columbia, Robert Boyd, Kenneth M. Ames, and Tony A. Johnson, editors, pp. 80105. University of Washington Press, Seattle, WA.

Byram, Scott

1996 On-Site Lithic Analysis Manual. Manuscript, Malheur National Forest, John Day, OR.

1998 Appendix II: Technological Analysis of Debitage from Site 45CL460. In Archaeology at the Long Jump Pit House Site (45CL460), Clark County, Washington, Douglas C. Wilson, editor, Report to Public Works of Clark County, WA, from Archaeology Consulting, Portland, OR.

Chance, David H. and Jennifer V. Chance

1976 Kanaka Village/Vancouver Barracks, 1974. Office of Public Archaeology, University of Washington, Seattle, WA.

Chance, David H., Jennifer V. Chance, Caroline Carley, Karl Gurcke, Timothy Jones, George Ling, Michael Pfeiffer, Karl Roenke, Jacqueline Storm, Robert Thomas and Charles Troup

1982 Kanaka Village/ Vancouver Barracks 1975. Office of Public Archaeology, University of Washington, Seattle, WA.

Clark, Jeffery T.

1981 Glass Scrapers from Historic North America. Lithic Technology 10: 31-34.

Cole, Douglas and David Darling

1990 History of Contact: History of the Early Period. In Handbook North American

Indians, Vol. 7, Northwest Coast, Wayne Suttles, editor, pp. 119-134. Smithsonian

Institution, Washington, DC.

Conte, Ignacio Clemente and Facundo Gómez Romero 2008 Microwear Analysis of Retouched Glass Fragments from Fortlet Miñana, Azul, Argentina, 1860-1863. International Journal of Historical Archaeology 12: 248-262.

Cooper, Zarine and Sandra Bowdler

1998 Flaked Glass Tools from the Andaman Islands and Australia. Asian Perspectives 31(1):74-83. 
Corney, Peter

1896 Early Northern Pacific Voyages. Thos. G. Thrum, Honolulu, HI.

Crean, J.F.

1962 Hats and the Fur Trade. The Canadian Journal of Economics and Political Science 28(3):373-386.

Cromwell, Robert J.

2006 "Where Ornament and Function Are So Agreeably Combined": Consumer Choice Studies of English Ceramic Wares at Hudson's Bay Company Fort Vancouver. Doctoral Dissertation, Department of Anthropology, Syracuse University, NY.

2010 A Typological Analysis of the Historic Ceramic Ware Sherds Recovered from the Cathlapotle (45CL1) Site and the Meier (35CO5) Site. Report to the Department of Anthropology, Portland State University, from Fort Vancouver National Historic Site, Vancouver, WA.

Davis, Debra

1998 Bone Tool Technology: Measurements of Curation and the Spatial Distribution of Bone and Antler Artifacts from a Pacific Northwest Plankhouse. Master's Thesis, Department of Anthropology, Portland State University, Portland, OR.

Davis, Sara J.

2010 Projectile Point Variation at the Meier (35CO5) and Cathlapotle (45CL1) Archaeological Sites. Master's Thesis, Department of Anthropology, Portland State University, Portland, OR.

Dawdy, Shannon Lee

2000 Preface, Evidence of Creolization in the Consumer Goods of an Enslaved Bahamiam Family. Historical Archaeology 34(3):1-4.

Dietler, Michael

1998 Consumption, Agency, and Cultural Entanglement: Theoretical Implications of a Mediterranean Colonial Encounter. In Studies in Culture Contact: Interaction, Culture Change, and Archaeology, James Cusick, editor, pp. 288-315. Center for Archaeological Investigations, Carbondale, IL.

Dobres, Marcia Ann. and Christopher R. Hoffman

1994 Social Agency and the Dynamics of Prehistoric Technology. Journal of Archaeological Method and Theory 1(3):211-58.

Dunn, John

1844 History of the Oregon Territory and British North American Fur Trade: With an Account of the Habits and Customs of the Principal Native Tribes on the Northern Continent. Edwards and Hughes, London, UK. 
Dunnell, Robert C. and Jan F. Simek

1995 Artifact Size and Plow Processes. Journal of Field Archaeology 22(3):305-319.

Elliott, T.C.

1915 The Fur Trade in the Columbia River Basin Prior to 1811. Washington Historical Quarterly 6(1):3-10.

1927 The Journal of the Ship Ruby. Oregon Historical Quarterly 28(3):258-280.

1931 British Values in Oregon, 1847. Oregon Historical Quarterly 32(1):27-45.

Ellis, David V.

n.d. Untitled manuscript report on the 1984 Willamette Associates' investigation in the Meier Site locality. Manuscript, Willamette Associates, Portland, OR.

Erigero, Patricia C.

1992 Cultural Landscape Report: Fort Vancouver National Historic Site. Vol. 2.

National Park Service, Seattle, WA.

Erlandson, Jon M., and Kevin Bartoy

1995 Cabrillo, the Chumash, and Old World diseases. Journal of California and Great Basin Anthropology 17(2):153-173.

Ferguson, Leland

2000 Introduction, Evidence of Creolization in the Consumer Goods of an Enslaved Bahamiam Family. Historical Archaeology 34(3):5-9.

Fletcher, Mike and Gary R. Lock

2005 Digging for Numbers, Elementary Statistics for Archaeologists, $2^{\text {nd }}$ edition.

Antony Rowe Ltd., Chippenham, UK.

Franchère, Gabriel

1969 Journal of a Voyage on the Northwest Coast of North America during the Years 1811, 1812, 1813, and 1814. W. Kaye and Wessie Lamb, translator and editors, Macmillan, Toronto, ON.

Frank, John W., Roland S. Moore, and Genevieve M. Ames

2000 Historical and Cultural Roots of Drinking Problems among American Indians. American Journal of Public Health 90(3): 344-351.

Fuld, Kristen A.

2012 The Technological Role of Bone and Antler Artifacts on the Lower Columbia: A Comparison of Two Contact Period Sites. Master's Thesis, Department of Anthropology, Portland State University. University Microfilms International, Ann Arbor, MI. 
Furgerson, Samuel

1810 Journal of a Voyage from Boston to the Northwest Coast of America, in the Brig Otter, Samuel Hill Commander. Ms. 207, Western Americana, Yale University Library, New Haven, CT.

Gardner-O'Kearny, William

2010 Hearth Features at the Meier and Cathlapotle Archaeological Sites. Master's

Thesis, Department of Anthropology, Portland State University, Portland, OR.

Gembala, Danielle, Robert Cromwell, and Douglas C. Wilson

2004 Results of the System-wide Archaeological Inventory Project Excavations in the HBC Village Site (45CL300) Fort Vancouver National Historic Site: 2001-2003.

Manuscript, Fort Vancouver National Historic Site, Vancouver, WA.

Gibbs, George

1877 Tribes of Western Washington and Northwestern Oregon with Map. In

Contributions to North American Ethnology, Vol. 1, J.W. Powell, editor, pp.157-241.

U.S. Department of the Interior, Washington, D.C.

Gibson, James R

1992 Otter Skins, Boston Ships, and China Goods: The Maritime Fur Trade of the Northwest Coast, 1785-1841. University of Washington Press, Seattle, WA.

Giddens, Anthony

1979 Central Problems in Social Theory: Action, Structure, and Contradiction in Social Analysis. University of California Press, Berkley, CA.

Hajda, Yvonne P.

1984 Regional Social Organization in the Greater Lower Columbia, 1792-1830.

Doctoral dissertation, Department of Anthropology, University of Washington.

University Microfilms International, Ann Arbor, MI.

Hajda, Yvonne P., and Elizabeth A. Sobel

2013 Lower Columbia Trade and Exchange Systems. In Chinookan Peoples of the

Lower Columbia, Robert Boyd, Kenneth M. Ames, and Tony A. Johnson, editors, pp.

106-124. University of Washington Press, Seattle, WA.

Hamilton, Stephen C.

1994 Technological Organization and Sedentism: Expedient Core Reduction,

Stockpiling, and Tool Curation at the Meier Site (35CO5). Master's Thesis, Department of Anthropology, Portland State University, Portland, OR. 
Harpole, Judith L.

2006 Dead Deer Do Tell Tales: Mammalian Systematic Paleontology and Temporal Variation at Cathlapotle, 45CL1, Southwestern Washington. Master's Thesis, Department of Anthropology, University of Missouri. University Microfilms International, Ann Arbor, MI.

Harrison, Brian F. 2002 Management Summary: Archaeological Survey and Test Excavations at Lewis and Clark's "Station Camp." Report to the National Park Service, Pacific West Regional Office, Seattle, from Columbia Diachronic Services, Astoria, OR.

2003 Archaeological Survey and Testing at Lewis and Clark's "Station Camp." Report to the National Park Service, Pacific West Regional Office, Seattle, from Columbia Diachronic Services, Astoria, OR.

2004 Preliminary Results of Archaeological Testing at McGowan/Station Camp (45 PC 106), June 2004. Report to the National Park Service, Pacific West Regional Office, Seattle, from Columbia Diachronic Services, Astoria, OR.

2005 Archaeological Survey and Testing at the Proposed Station Camp Interpretive Park, McGowan, Washington. Report to the National Park Service, Pacific West Regional Office, Seattle, from Columbia Diachronic Services, Astoria, OR.

Harrison, Rodney

2003 'The Magical Virtue of these Sharp Things': Colonialism, Mimesis and Knapped Bottle Glass Artifacts in Australia. Journal of Material Culture 8(3):311-336.

Hodder, Ian

1974 Regression Analysis of Some Trade and Marketing Patterns. World Archaeology 6(2):172-189.

Holschuh, Dana L.

2013 An Archaeology of Capitalism: Exploring Ideology through Ceramics from the Fort Vancouver and Village Sites. Master's Thesis, Department of Anthropology, Portland State University. University Microfilms International, Ann Arbor, MI.

Hussey, John

n.d.(a) The Hudson Bay Company and the Pacific Northwest Indians. Manuscript, Fort Vancouver National Historic Site, Vancouver, WA.

n.d.(b) Hudson's Bay Company Fur Brigades in the Columbia Department. Manuscript, Fort Vancouver National Historic Site, Vancouver, WA.

1957 History of Fort Vancouver and its Physical Structure. Abbot, Kerns \& Bell, Portland, OR. 
1972 Historic Structures Report, Historical Data, Volume I, Fort Vancouver National Historic Site, Washington. U.S.D.I., National Park Service, Denver Service Center, Denver, CO.

1977 The Women of Fort Vancouver. Manuscript, Fort Vancouver National Historic Site, Vancouver, WA.

Jackman, S.W. (editor)

1978 The Journal of William Sturgis. Sono Nis Press, Victoria, BC.

Jenkins, Dennis L., and Thomas J. Connolly 1996 Mid-Holocene Occupations at the Heath Cliffs Site, Warm Springs Reservation, Oregon. University of Oregon Anthropological Papers 53. Department of Anthropology and Oregon State Museum of Anthropology, University of Oregon, Eugene, OR.

Jetté, Melinda Marie

2006/2007 "Beaver Are Numerous, but the Native...Will Not Hunt Them": NativeFur Trade Relations in the Willamette Valley, 1812-1814. The Pacific Northwest Quarterly 98(1):3-17.

Johnson, Matthew H.

1989 Conceptions of Agency in Archaeological Interpretation. Journal of Anthropological Archaeology 8(2): 198-211.

Jones, Robert Francis (editor) 1999 Annals of Astoria: The Headquarters Log of the Pacific Fur Company on the Columbia River, 1811-1813. Fordham University Press, New York, NY.

Jopling, Carol F. 1989 The Coppers of the Northwest Coast Indians: Their Origin, Development and Possible Antecedents. Transactions of the American Philosophical Society 79(1):1-164.

Joyce, Arthur A. and Marcus Winter 1996 Ideology, Power, and Urban Society in Pre-Hispanic Oaxaca. Current Anthropology 37(1): 33-47.

Kaehler, Gretchen A.

2002 Patterns in Glass: Interpretation of European Glass Trade Beads from Two Protohistoric Sites in the Greater Lower Columbia Region. Master's Thesis, Department of Anthropology, Portland State University, Portland, OR. 
Kardas, Susan

1971 The People Bought This and the Clatsop Became Rich: a View of Nineteenth Century Fur Trade Relationships on the Lower Columbia between Chinookan Speakers, Whites, and Kanakas. Doctoral Dissertation, Department of Anthropology, Bryn Mawr College. University Microfilms International, Ann Arbor, MI.

Kardas, Susan and Edward M. Larrabee 19701969 Excavations at Kanaka Village Site, Fort Vancouver, Washington. National Park Service, Fort Vancouver National Historic Site, Vancouver, WA.

Kehrberg, Ina 1992 Flaked Glass and Pottery Sherd Tools of the Late Roman and Byzantine Periods from the Hippodrome from at Jerash. Syria 69(3/4): 451-464.

Kimura, Birgitta

2006 Knapped Glass Tools from Konso, Southern Ethiopia. Manuscript, Department of Anthropology, University of Florida, Gainesville, FL.

Lang, William L.

2013 The Chinookan Encounter with Euro-Americans in the Lower Columbia River Valley. In Chinookan Peoples of the Lower Columbia, Robert Boyd, Kenneth M. Ames, and Tony A. Johnson, editors, pp. 250-271, University of Washington Press, Seattle, WA.

Lightfoot, Kent G.

1995 Culture Contact Studies: Redefining the Relationship between Prehistoric and Historical Archaeology. American Antiquity 60:199-217.

2005 Indians, Missionaries, and Merchants: The Legacy of Colonial Encounters on the California Frontiers. University of California Press, Berkley, CA.

Lightfoot, Kent G., and Antoinette Martinez 1995 Frontiers and Boundaries in Archaeological Perspective. Annual Review of Anthropology 24:471-492.

Lightfoot, Kent G., Antoinette Martinez, and Ann M. Schiff 1998 Daily Practice and Material Culture in Pluralistic Social Settings: An Archaeological Study of Culture Change and Persistence from Fort Ross, California. American Antiquity 63(2):1999-222.

Lindsey, Bill

2013 Historic Glass Bottle Identification \& Information Website. Society for Historical Archaeology and Bureau of Land Management, <http://www.sha.org/bottle/>. 
Little, Barbara J.

2007 Historical Archaeology: Why the Past Matters. Left Coast Press, Inc., Walnut Creek, CA.

Lyman, R. Lee

1994 Mammalian Zooarchaeology of the Meier Site (35CO5). Report to the Department of Anthropology, Portland State University, from the Department of Anthropology, University of Missouri, Columbia, MO.

2003 Mammalian Zooarchaeology of Cathlapotle (45CL1): Descriptive Paleontology and Taphonomic Analysis. Report to the Department of Anthropology, Portland State University, from the Department of Anthropology, University of Missouri, Columbia, MO.

Mackie, Richard Somerset

1997 Trading Beyond the Mountains: The British Fur Trade on the Pacific 1793-1843.

UBC Press, Vancouver, B.C.

Malloy, Mary

1998 "Boston Men" on the Northwest Coast: The American Maritime Fur Trade 17881844. University of Alaska Press, Fairbanks, AK.

Mallouf, Robert J.

1982 An Analysis of Plow-Damaged Chert Artifacts: The Brookeen Creek Cache (41HI86), Hill County, Texas. Journal of Field Archaeology 9(1):79-98.

Manby, Thomas

1992 Journal of the Voyages of the H.M.S. Discovery and Chatham. Ye Galleon Press, Fairfield, WA.

Martindale, Andrew

2009 Entanglement and Tinkering: Structural History in the Archaeology of the Northern Tsimshian. Journal of Social Archaeology. 9(1):59-91

Martindale, Andrew and Irena Jurakic

2006 Identifying Expedient Glass Tools from a Post-Contact Tsimshian Village using Low Power (10-100x) Magnification. Journal of Archaeological Science. 33:414-427.

McDougall, Dennis P.

1990 The Bottles of the Hoff Store Site. In The Hoff Store Site and Gold Rush Merchandise from San Francisco, California, Special Publication Series No. 7, Allen G. Pastron and Eugene M. Hattori, editors, pp.58-74. The Society for Historical Archaeology, Ann Arbor, MI. 
McLellan, Sister Mary de Sales

1935 Vancouver, Washington, 1846 to 1870, with an Introduction Covering the Hudson's Bay Period. Master's Thesis, University of Oregon, Eugene, OR.

Merck, Frederick (editor)

1968 Fur Trade and Empire: George Simpson's Journal Entitled Remarks Connected with The Fur Trade in The Course of a Voyage from York Factory to Fort George and Back to York Factory 1824-1825. Belknap Press of Harvard University Press, Cambridge, MA.

Minor, Rick and Laurie E. Burgess

2009 Chinookan Survival and Persistence on the Lower Columbia: The View from the Kathlamet Village. Historical Archaeology 43(4):97-114.

Moulton, Gary E. (editor)

1990 The Journals of the Lewis and Clark Expedition, Volume 6: November 2, 1805March 22, 1806. University of Nebraska Press, Lincoln, NE.

1990 The Journals of the Lewis and Clark Expedition, Volume 7: March 23-June 9, 1806. University of Nebraska Press, Lincoln, NE.

Mullaley, Meredith J.

2011 Rebuilding the Architectural History of the Fort Vancouver Village. Master's Thesis, Department of Anthropology, Portland State University. University Microfilms International, Ann Arbor, MI.

Mullins, Paul R.

2008 The Strange and Unusual: Material and Social Dimensions of Chinese Identity. Historical Archaeology 42(3):152-157.

Odell George H. and Frank Cowan

1987 Estimating Tillage Effects on Artifact Distributions. American Antiquity 52(3): 456-484.

Orser, Charles E., Jr

1996 A Historical Archaeology of the Modern World. Plenum Publishers, New York, NY.

2004 Historical Archaeology, $2^{\text {nd }}$ edition. Pearson, Prentice Hall, Upper Saddle River, NJ.

Ortner, Sherry B.

1984 Theory in Anthropology since the Sixties. Reprinted 1994 In

Culture/Power/History: A Reader in Contemporary Social Theory, Nicholas B. Dirks, Geoff Eley, and Sherry B. Ortner, editors, pp. 372-411. Princeton University Press, Princeton, NJ. 
1996 Making Gender: The Politics and Erotics of Culture. Beacon Press, Boston, MA.

2006 Anthropology and Social Theory. Duke University Press, Durham, NC.

Pauketat, Timothy R.

2000 The Tragedy of the Commoners. In Agency in Archaeology, Marcia Ann Dobres and John Robb, editors, pp. 113-129. Routledge, New York, NY.

Pettigrew, Richard M.

1981 Prehistoric Culture Sequences in the Portland Basin of the Lower Columbia River Valley. Anthropological Papers No. 22. University of Oregon, Eugene, OR.

Plummer, Catherine

1991 The Shogun's Reluctant Ambassadors: Japanese Sea Drifters in the North

Pacific. Oregon Historical Society, Portland, Oregon.

Ray, Verne

1938 Lower Chinook Ethnographic Notes. University of Washington Publications in Anthropology 7(2):29-165, Seattle, WA.

Renfrew, Colin

1972 The Emergence of Civilization: the Cyclades and the Aegean in the Third Millennium BC. Methuen, London.

Ronda, James

1984 Lewis and Clark among the Indians. University of Nebraska Press, Lincoln, NE.

Rich, E.E. (editor)

1941 The Letters of John McLoughlin, from Fort Vancouver to the Governor and Committee, First Series, 1825-1838. Champlain Society, Toronto, ON.

1943 The Letters of John McLoughlin, from Fort Vancouver to the Governor and Committee, Second Series, 1839-1844. Champlain Society, Toronto, ON.

Robbins, Lawrence H., Alec C. Campbell, and Michael L. Murphy 2004 Retouched Glass Dated to the Late $19^{\text {th }}$ Century at Toteng, Botswana. Nyame Akuma 62:11-18.

Rodríguez-Alegría, Enrique

2010 Incumbents and Challengers: Indigenous Politics and the Adoption of Spanish Material Culture in Colonial Xaltocan, Mexico. Historical Archaeology 44(2): 51-71. 
Ross, Alexander

1849 Adventures of the First Settlers on the Columbia River. Smith, Elder and Co., London. Reprinted 1966 by University Microfilms Inc., Ann Arbor, MI.

Ross, Lester A.

1976 Fort Vancouver 1829-1860: A Historical Archaeological Investigation of the Goods Imported and Manufactured by the Hudson's Bay Company. Manuscript, Fort Vancouver National Historic Site, Vancouver, WA.

Roulstone, Thomas B.

1975 A Social History of Fort Vancouver 1829-1849. Master's Thesis, Department of History, Utah State University, Logan, UT.

Rubertone, Patricia E.

2000 The Historical Archaeology of Native Americans. Annual Review of Anthropology 29:425-446.

Ruby, Robert H. and John A. Brown

1976 The Chinook Indians: Traders of the Lower Columbia River. University of Oklahoma Press, Norman, OK.

Runnels, Curt

1975 A Note on Glass Implements in Greece. Lithic Technology 4(3):29-30.

1976 More on Glass Implements from Greece. Lithic Technology 5(3):27-31.

Sahlins, Marshall David

1981 Historical Metaphors and Mythical Realities: Structure in the Early History of the Sandwich Islands Kingdom. University of Michigan Press, Ann Arbor, MI.

Schiffer, Michael B.

1987 Formation Processes of the Archaeological Record. University of Utah Press, Salt Lake, UT.

Schwantes, Carlos Arnaldo

1996 The Pacific Northwest: An Interpretive History. University of Nebraska Press, Lincoln, NE.

Silliman, Stephen W.

2001 Agency, Practical Politics, and the Archaeology of Culture Contact. Journal of Social Archaeology 1(2):190-209.

2005 Culture Contact or Colonialism? Challenges in the Archaeology of Native North America. American Antiquity 70(1):55-74. 
Silverstein, Michael

1990 Chinookans of the Lower Columbia. In Handbook North American Indians, Vol.

7, Northwest Coast, Wayne Suttles, editor, pp. 533-546. Smithsonian Institution,

Washington, DC.

Smith, Cameron McPherson

2004 The Social Organization of Production in Three Protohistoric Lower Columbia

River Plankhouses. Doctoral Dissertation, Department of Archaeology, Simon Fraser University. University Microfilms International, Ann Arbor, MI.

2009 Lithic Assemblage. In Historical Archaeology at the Middle Village, Station Camp/McGowan Site (45PC106), Station Camp Unit, Lewis and Clark National Historic

Park, Pacific County, Washington, Douglas C. Wilson, editor, pp. 257-275. National

Park Service, Northwest Cultural Resources Institute, Report No. 1, Vancouver, WA

Sobel, Elizabeth A.

2004 Social Complexity and Corporate Households on the Southern Northwest Coast of North America, A.D. 1450-1855. Doctoral Dissertation, Department of Anthropology, University of Michigan. University Microfilms International, Ann Arbor, MI.

2011 An Archaeological Test of the "Exchange Expansion Mode" of Contact Era Change on the Northwest Coast. Journal of Anthropological Archaeology 31(1):1-21

Stahl, Ann Brower.

2002 Colonial Entanglements and the Practices of Taste: An Alternative to Logocentric Approaches. American Anthropologist 104(3): 827-45.

Stern, Theodore

1998 Columbia River Trade Network. In Handbook of North American Indians, Vol.

12, Plateau, D.E. Walker, editor , pp. 641-652. Smithsonian Institution, Washington, DC.

Sullivan, Alan P., and Keneth C. Rozen

1985 Debitage Analysis and Archaeological Interpretation. American Antiquity 50(4):755-779.

Thomas, Bryn

1987 Archaeological Testing and Data Recovery Excavation for a Proposed Utility Corridor at Fort Vancouver National Historic Site. Report to the Washington State Department of Transportation, from Archaeological and Historical Services, Eastern Washington University Archaeological and Historical Services, Cheney, WA.

1993 Archaeological Test Excavations for the Washington State Department of Transportation's SR 14 Pedestrian Undercrossing Project at Fort Vancouver National Historic Site, Clark County Washington. Report to the Washington State Department of Transportation, from Archaeological and Historical Services, Eastern Washington University Archaeological and Historical Services, Cheney, WA. 
Thomas, Bryn and Charles Hibbs Jr.

1984 Report of Investigations of Excavations at Kanaka Village/Vancouver Barracks, Washington, 1980/1981. Report to the Washington State Department of Transportation, from Archaeological and Historical Services, Eastern Washington University Archaeological and Historical Services, Cheney, WA.

Thomas, Nicholas

1991 Entangled Objects: Exchange, Material Culture and Colonialism in the Pacific. Harvard University Press, Cambridge, MA.

Thrush, Coll

2011 Vancouver the Cannibal: Cuisine, Encounter, and the Dilemma of Difference on the Northwest Coast, 1774-1808. Ethnohistory 58(1):1-35.

Upton, Dell

1996 Ethnicity, Authenticity, and Invented Tradition. Historical Archaeology 30(2):17.

Vancouver, George 1984 A Voyage of Discovery to the North Pacific Ocean and Round the World, 17911795: with an Introduction and Appendices, Vol. 2. W. Kaye Lamb, editor. Hakluyt Society, London.

Van Pool, Todd L. and Robert D. Leonard

2011 Quantitative Analysis in Archaeology. Wiley-Blackwell, Malden, MA.

Veth, Peter and Susan O'Connor

2005 Archaeology, Claimant Connection to Sites, and Native Title: Employment of Successful Categories of Data with Specific Comments on Glass Artifacts. Australian Aboriginal Studies 2005 (1): 2-17.

Vibert, Elizabeth

1997 Traders' Tales: Narratives of Cultural Encounters in the Columbia Plateau 18071846. University of Oklahoma Press, Norman, OK.

Voss, Barbara L.

2008 The Archaeology of Ethnogenesis: Race and Sexuality in Colonial San Francisco. University of California Press, Berkley, CA.

Warner, Mikell de Lore Wormell, and Harriet Duncan Munnick 1972 Catholic Church Records of the Pacific Northwest: Vancouver, Volumes I \& II, and Stellamaris Mission. French Prairie Press, St. Paul, MN.

Webb, Malcolm C.

1974 Exchange Networks: Prehistory. Annual Review of Anthropology 3: 357-383. 
Whaley, Gray

2007 "Complete Liberty"? Gender, Sexuality, Race, and Social Change on the Lower Columbia River: 1805-1838. Ethnohistory 54(4):669-695.

Wilkes, Charles

1845 Narrative of the United States Exploring Expedition. During the Years 1838, 1839, 1840, 1841, 1842. Vol. IV. Lea and Blanchard, Philadelphia, PA. Reprinted 1970 by The Gregg Press, Upper Saddle River, NJ.

Wilkie, Laurie A.

1996 Glass-Knapping at a Louisiana Plantation: African-American Tools? Historical Archaeology 30(4):37-49.

Wilson, Douglas C.

2005 The Confluence Project Land Bridge at The Vancouver national Historic Reserve, Vancouver Washington: Archaeological Survey, Test Excavations and Treatment Plan. Manuscript, Fort Vancouver National Historic Site, Vancouver, WA.

2010 Research Design: 2010 Public Archaeology Field School and Associated Processing of Artifacts at Fort Vancouver National Historic Site, Vancouver, Washington. Manuscript, Fort Vancouver National Historic Site, Vancouver, WA.

Wilson, Douglas C, Kenneth M Ames, Kristine M Bovy, Virginia L Butler, Robert J Cromwell, Loren G Davis, Christoper R DeCorse, Brian F Harrison, R Lee Lyman, Michele L Punke, Cameron M Smith, and Nancy A Stenholm.

2009 Historical Archaeology at the Middle Village, Station Camp/McGowan Site (45PC106), Station Camp Unit, Lewis and Clark National Historic Park, Pacific County, Washington. National Park Service, Northwest Cultural Resources Institute, Report No. 1 , Vancouver, WA.

Wilson, Douglas, Robert Cromwell, Danielle Gembala, Theresa Langford, Heidi Pierson, and Debra Semrau.

2011 Archaeology Lab Manual, $3^{\text {rd }}$ Edition. Manuscript, Fort Vancouver National Historic Site, Vancouver, WA.

Wilson, Samuel M., and J. Daniels Rogers 1993 Historical Dynamics in the Contact Era. In Ethnohistory and Archaeology: Approaches to Postcontact Change in the Americas, J. Daniels Rogers and Samuel M. Wilson, editors, pp. 3-15. Plenum, New York, NY.

Wolf, Eric R.

1982 Europe and The People Without History. University of California Press, Berkeley, CA. 
Wolf, John W.

1994 The Spatial Distribution of Ground Stone Tools as a Marker of Status Differentials in a Chinookan Plank House on the Lower Columbia River. Master's Thesis, Department of Anthropology, Portland State University, Portland, OR.

Wuerch, William

1979 History of the Middle Chinook to the Reservation Era. Master's Thesis, Department of History, University of Oregon, Eugene, OR.

Wynia, Katie A.

2013 The Spatial Distribution of Tobacco Pipe Fragments at the Hudson's Bay Company Fort Vancouver Village Site: Smoking as a Shared and Social Practice. Master's Thesis, Department of Anthropology, Portland State University. University Microfilms International, Ann Arbor, MI.

Zehr, Jamey

2002 A Study o f a Sample of Mammalian Remains from Cathlapotle (45CL1), Southwestern Washington. Master's Thesis, University of Missouri, Columbia, MO. 
Appendix A: Examples of Modified Glass Tools

\section{Cathlapotle}

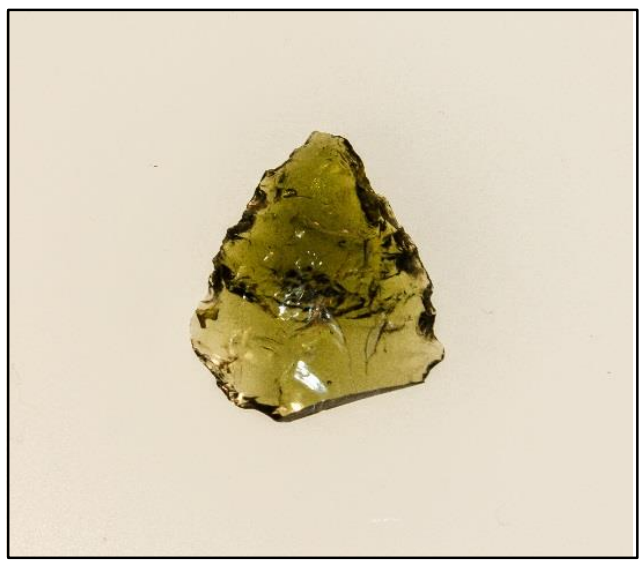

Catalog No. 20014

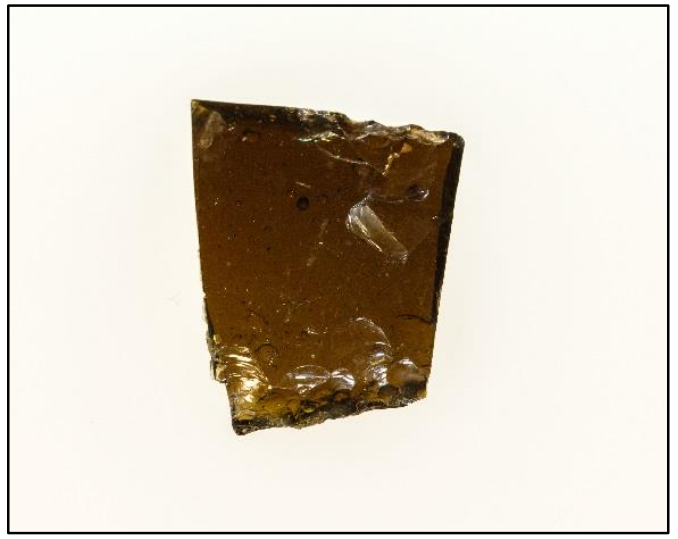

Catalog No. 27305

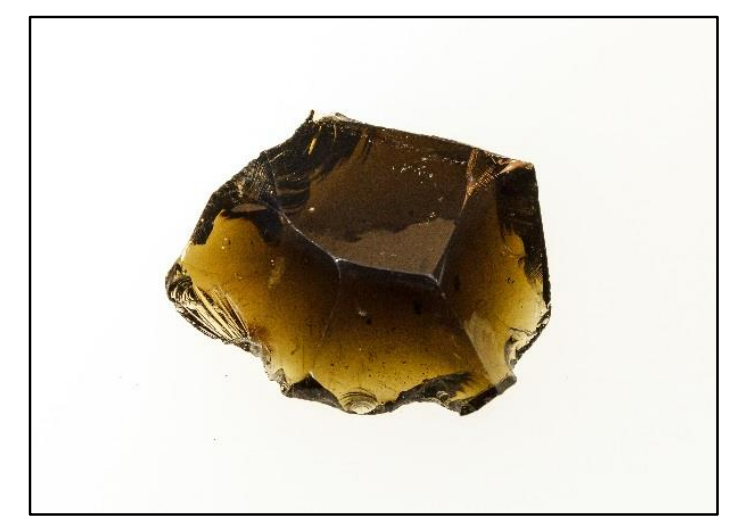

Catalog No. 42023 


\section{Meier}

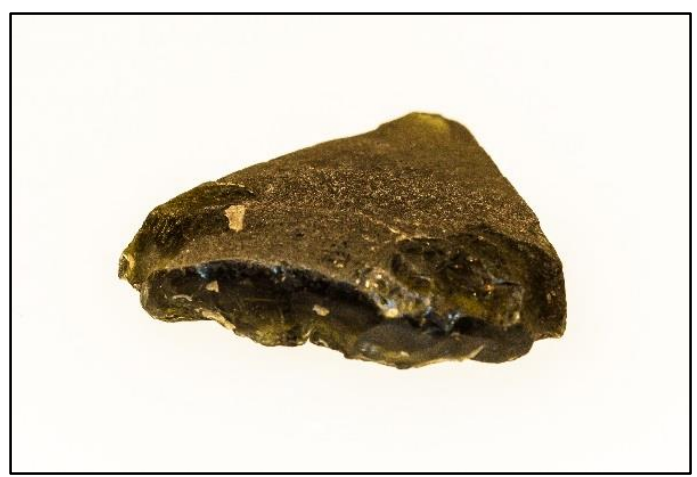

Catalog No. 1886

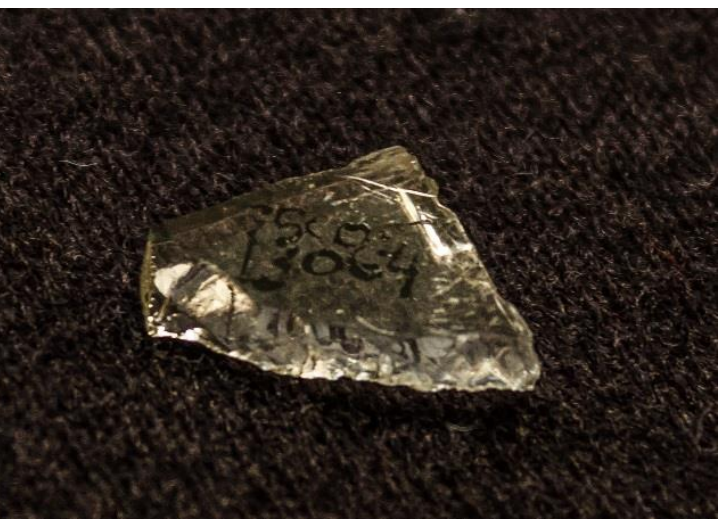

Catalog No. 13064

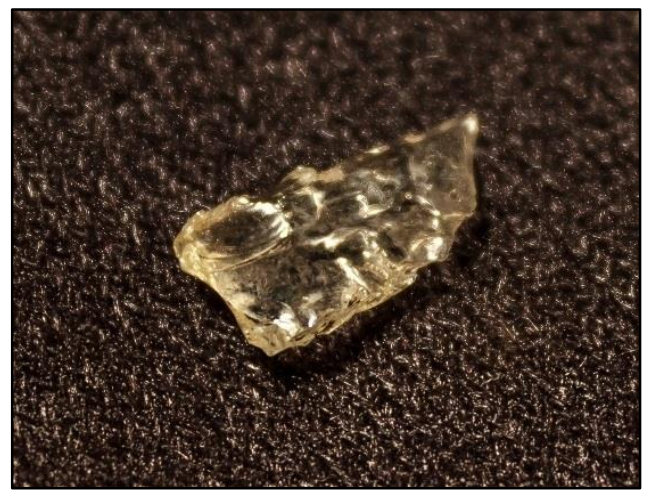

Catalog No. 13065 


\section{Operation 56}

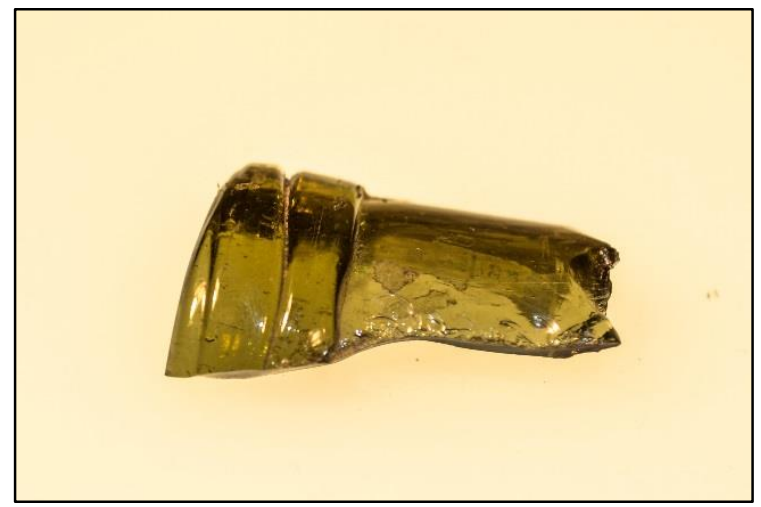

Accession No. FOVA-01813

Catalog No. FOVA-16341

\section{Operation 57}

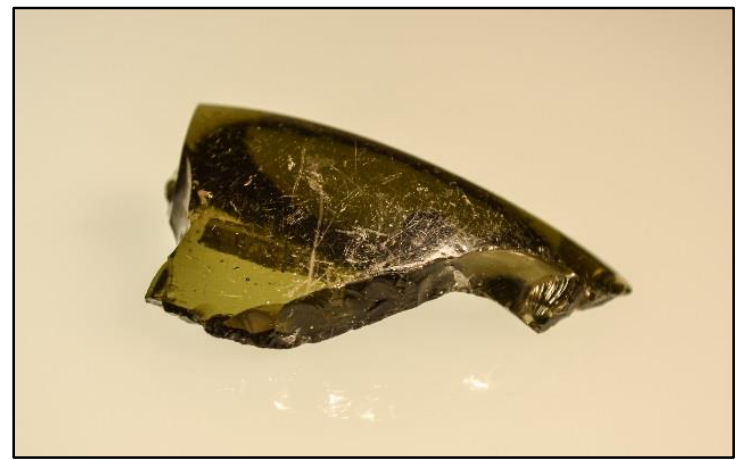

Accession No. FOVA-01813

Catalog No. FOVA-62813

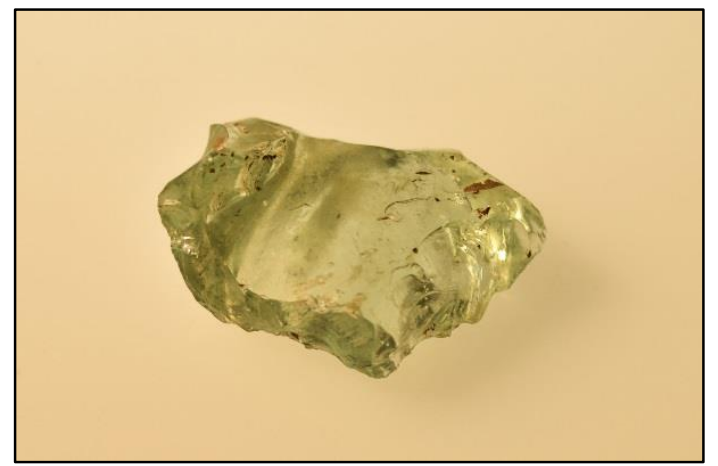

Accession No. FOVA-01813

Catalog No. FOVA-16409

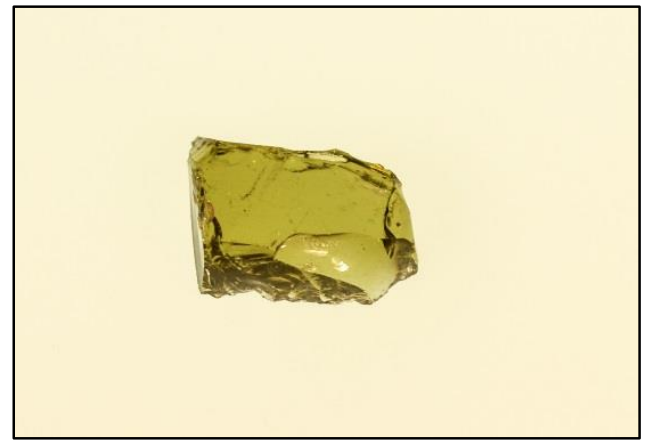

Accession No. FOVA-01813

Catalog No. FOVA-63113

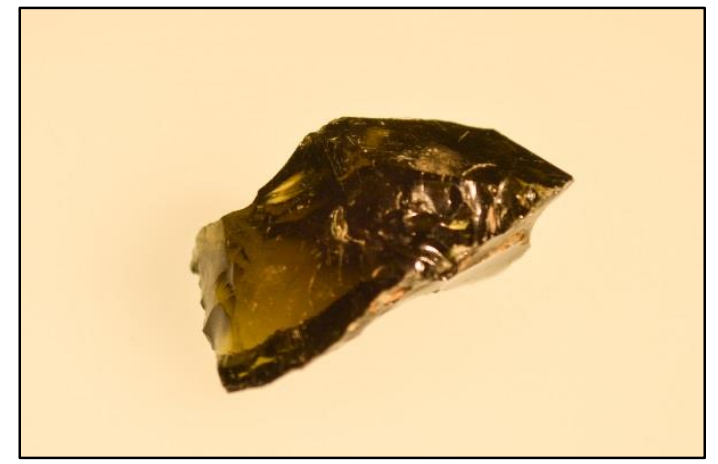

Accession No. FOVA-01813

Catalog No. FOVA-62991 